UNIVERSIDADE ESTADUAL PAULISTA

CAMPUS EXPERIMENTAL DO LITORAL PAULISTA

UNIDADE DE SÃO VICENTE

\title{
PARQUE ESTADUAL XIXOVÁ-JAPUÍ: ANÁLISE DO RELACIONAMENTO COM A POPULAÇÃO DE ENTORNO (BAIRRO JAPUÍ)
}

Michele Correa Lau

São Vicente - SP

2008 
UNIVERSIDADE ESTADUAL PAULISTA

CAMPUS EXPERIMENTAL DO LITORAL PAULISTA

UNIDADE DE SÃO VICENTE

\title{
PARQUE ESTADUAL XIXOVÁ-JAPUÍ: ANÁLISE DO RELACIONAMENTO COM A POPULAÇÃO DE ENTORNO (BAIRRO JAPUÍ)
}

\author{
Michele Correa Lau
}

Orientador: Prof. Dr. Denis Moledo de Souza Abessa

Co-orientador: Prof. Dr. Rogério Hartung Toppa

\begin{abstract}
Trabalho de Conclusão de Curso apresentado ao Campus do Litoral Paulista - UNESP, como parte dos requisitos para a obtenção do título de Bacharel em Ciências Biológicas, modalidade Biologia Marinha.
\end{abstract}

São Vicente - SP 
Lau, Michele Correa

Parque Estadual Xixová-Japuí: análise do relacionamento com a população de entorno (Bairro Japuí). / Michele Correa Lau. - São Vicente, 2008 $112 p$.

Trabalho de conclusão (Bacharelado - Ciências Biológicas) - Universidade Estadual Paulista, Campus Experimental do Litoral Paulista.

Orientador: Denis Moledo de Souza Abessa

Co-orientador: Rogério Hartung Toppa

1. Ecologia humana 2. Parque Estadual Xixová-Japuí

CDD 304.2

Palavras-chaves: Unidade de Conservação; Parque Estadual Xixová-Japuí; Rede sócio-técnica, Comunidade de Entorno 
Dedico:

Ao esforço de quem acredita

À vontade de quem ajuda

À paciência de quem espera e

aos que juntos, nunca desistem. 
"Negar nossa posição única e especial no mundo natural pode parecer uma atitude convenientemente modesta aos olhos da eternidade. Mas essa negativa poderia ser usada como uma desculpa para fugir às nossas responsabilidades. A verdade é que nenhuma outra espécie, em tempo algum, teve um 'domínio' tão completo e absoluto sobre tudo o que existe na Terra, vivo ou morto, como nós temos hoje. Esse poder nos lega, independentemente de nossa vontade, uma responsabilidade terrível. Em nossas mãos se encontra não apenas nosso próprio futuro, mas o de todos os outros seres vivos com os quais compartilhamos a Terra." ATTENBOROUGH, 1981.

"A tendência da sociedade humana de impor especializações às individualidades acaba por reduzir e inibir a diversidade criada pelo seu próprio desenvolvimento!" DI CIOMMO, 2003.

"Basta ser sincero e desejar profundo, você será capaz de sacudir o mundo." 


\section{AGRADECIMENTOS}

Agradeço aos moradores do Bairro Japuí e aos membros da ONG "SOS Itaquitanduva" que prontamente me receberam e colaboraram imensamente para a realização desse trabalho, bem como fizeram os Srs. Fernando Licth, Eduardo Lourenço e Julio Vellardi.

Agradeço também ao meu orientador, Denis Abessa, e ao meu co-orientador, Rogério Toppa, por darem todo apoio necessário à conclusão desse trabalho, se fazendo presentes em todos meus momentos de dúvidas e dificuldades.

Agradeço a todos os funcionários e professores do Campus Experimental do Litoral Paulista por terem me conferido meios práticos e teóricos para a execução desse trabalho, bem como por uma formação de qualidade.

Agradeço ao meu namorado pela compreensão de que esse trabalho me tirava um pouco da consciência companheira, mas que mesmo assim me ajudou tanto quanto podia. Não poderia deixar de agradecer a todos que de alguma maneira, direta e indiretamente, colaboraram para a conclusão desse trabalho, em especial à Bibian, Flora, Luis Dalsin, Luana, Julia, Sandra, Dominique, Kátia M. e Kátia C., por viverem junto a tensão de um TCC e saberem dissipá-la como ninguém, além de terem dividido sentimentos e momentos, nunca a bastar. 


\section{SUMÁRIO}

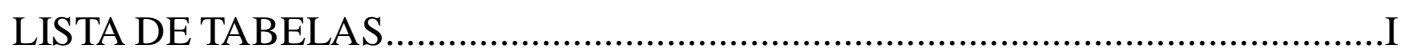

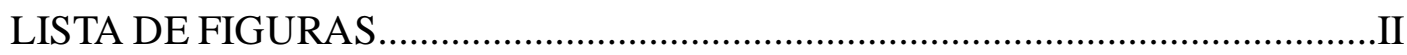

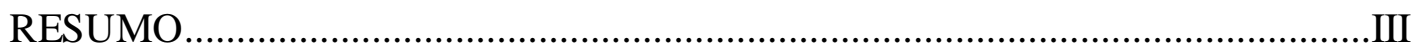

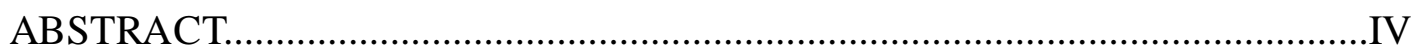

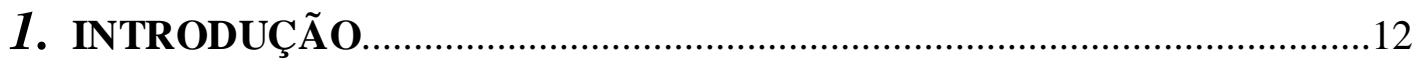

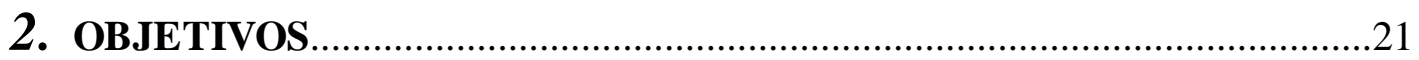

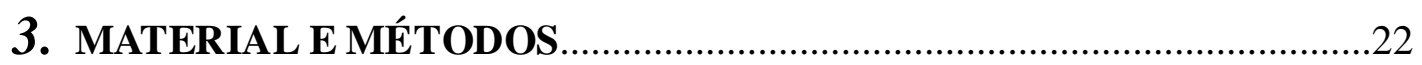

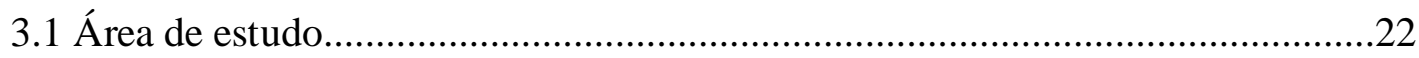

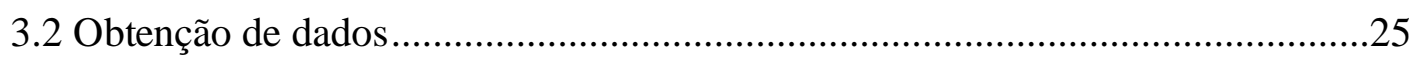

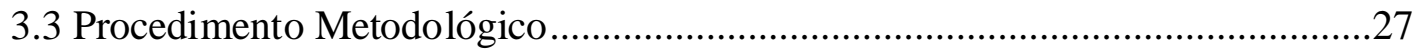

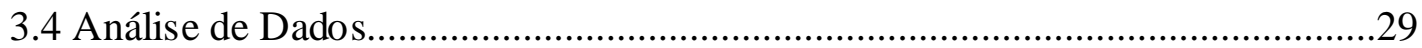

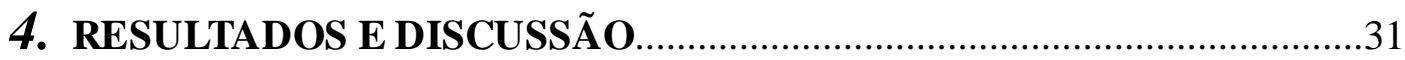

4.1 Histórico do desenvolvimento local...................................................................

4.2 Histórico do território do Parque Estadual Xixová-Japuí...................................41

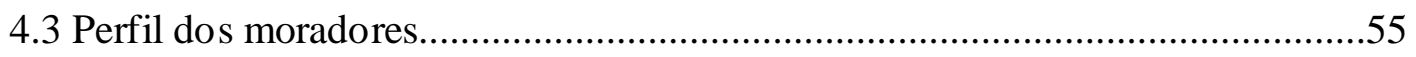

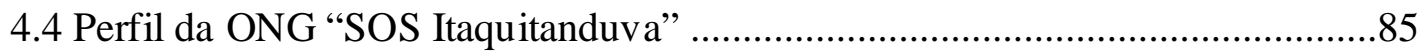

4.5 Avaliação de Políticas Públicas..........................................................................90

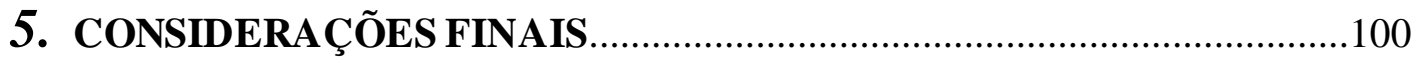

6. CONCLUSÃO

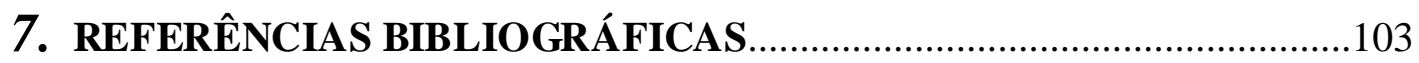

8. ANEXOS 


\section{LISTA DE TABELAS}

Tabela 1 - Categorias de Unidade de Conservação............................................................15

Tabela 2 - Porcentagem e número de entrevistados quanto ao tempo de moradia................52

Tabela 3 - Número e porcentagem dos moradores quanto à escolaridade............................53

Tabela 4 - Número e porcentagem de moradores quanto à ocupação...................................54

Tabela 5 - Número de citações e porcentagem das diferenças quanto aos serviços do meio ambiente

Tabela 6 - Número de citações e porcentagem das diferenças quanto aos cuidados com a área.

Tabela 7 - Número de citações e porcentagem dos benefícios quanto aos serviços do meio ambiente

Tabela 8 - Número de citações e porcentagem dos benefícios quanto à recreação

Tabela 9 - Número de citações e porcentagem dos benefícios quanto à beleza.....................70

Tabela 10-Número de citações e porcentagem dos prejuízos quanto à segurança e

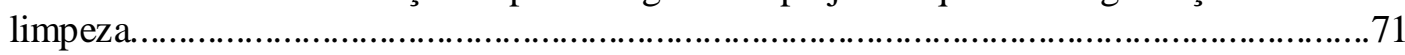

Tabela 11 - Acertos e erros para as atividades citadas como permitidas na área do PEXJ (considerando o atual Plano de Manejo).

Tabela 12 - Acertos e erros para as atividades citadas como proibidas na área do PEXJ (Considerando que o PEXJ não está efetivamente implementado).

Tabela 13- Representação da avaliação de política públicas do bairro Japuí de 1960 à 2004. 


\section{LISTA DE FIGURAS}

Figura 1 - Localização do Parque Estadual Xixová Japuí (Amarelo), com detalhe para o Bairro Japuí. Fonte: Google Earth....

Figura 2 - Limites da área de estudo, Bairro Japuí. Acervo Fotográfico Digital UNESP-

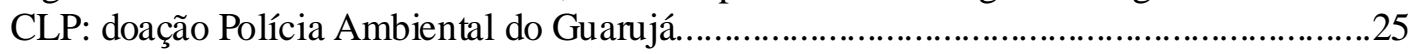

Figura 3 - Figura esquemática das ruas do Japuí. Fonte Google Earth.................................32

Figura 4 - Gráfico do intervalo de idades dos moradores e suas respectivas porcentagens...52

Figura 5 - Gráfico representando a porcentagem de moradores quanto a freqüência de

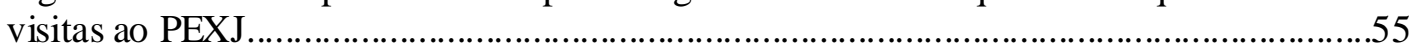

Figura 6 - Gráfico das atividades desenvolvidas no território do PEXJ, antes e depois de sua

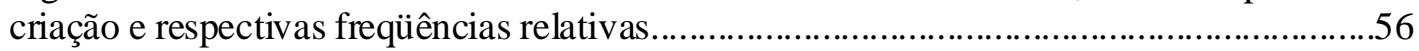

Figura 7 - Gráfico dos representantes de mamíferos citados e respectivas porcentagens. Dentre a série outros estão, com $2 \%$ das citações, veado, preá, sagüi e esquilo; com $1 \%$ vaca, tamanduá, rato do banhado, quati, lebre, cutia.........................................................57

Figura 8 - Porcentagem das diferenças citadas quanto à conservação/preservação...............59

Figura 9 - Porcentagem das diferenças citadas quanto ao aspecto cênico............................60

Figura 10 - Porcentagem das classes de problemas citados..............................................62

Figura 11 - Problemas quanto a conservação e respectivas sugestões de correção mencionadas pelos entrevistados

Figura 12 - Problemas quanto à segurança e respectivas sugestões de correção mencionadas pelos entrevistados.

Figura 13 - Problemas quanto à gestão e respectivas sugestões de correção mencionadas pelos entrevistados

Figura 14 - Problemas quanto à ocupação e respectivas sugestões de correção mencionadas pelos entrevistados

Figura 15 - Problemas quanto à limpeza e respectivas sugestões de correção mencionadas pelos entrevistados.

Figura 16 - Porcentagem das classes de benefícios citados

Figura 17 - Porcentagem dos lugares citados onde se instalaria a sede administrativa do PEXJ de acordo com os moradores que afirmaram saber da existência desta.

Figura 18 - Porcentagem de lugares citados onde pensou se instalar a sede administrativa do PEXJ de acordo com os moradores que não sabem da existência desta.

Figura 19 - Placa com informações sobre atividades proibidas. .75

Figura 20 - Porcentagem de convites para participar de eventos relacionados ao PEXJ quanto a quem convidou. .77

Figura 21 - Classificação da disponibilidade de informações para a comunidade e respectivas porcentagens.

Figura 22 - Classificação da gestão do PEXJ e respectivas porcentagens

Figura 23 - Classificação do relacionamento da comunidade com o território do PEXJ e respectivas porcentagens. 


\section{RESUMO}

O objetivo deste trabalho foi analisar o relacionamento estabelecido entre a comunidade de entorno do Bairro Japuí, situado no município de São Vicente, e o Parque Estadual Xixová-Japuí (PEXJ). Para tal, aplicou-se questionários sócioecólogicos a moradores do bairro, membros da ONG "SOS Itaquitanduva" e o gestor da unidade. Foram abordados aspectos como informação ambiental, relacionamento com o território da unidade, conhecimento e a disponibilidade de informação sobre o Parque. Foram tomados relatos históricos sobre a evolução do bairro junto aos moradores mais antigos e entrevistas foram realizadas com diferentes segmentos da sociedade sobre a evolução administrativa do Parque, situação atual deste e assuntos correlatos. A análise revelou que se trata de um bairro de classe baixa, cujos moradores apresentam baixo grau de instrução. O histórico da comunidade mostra a ausência de Políticas Públicas capazes de atender as demandas locais. Uma vez que a comunidade não foi incluida na gestão, seu relacionamento com a administração do Parque é praticamente inexistente, baseado na falta comunicação. Os moradores do bairro têm pouco conhecimento e interesse sobre o Parque e sua administração não apresentou sucesso em envolver a comunidade nos processos de gestão. Tal situação leva a outros problemas, como uma relação conflituosa en tre a ONG e o Parque, além de culminar em um cenário onde a gestão não é baseada em preceitos participativos.

Palavras-chave: Unidade de Conservação; Parque Estadual Xixová-Japuí; Rede sócio-técnica; Comunidade de entorno. 


\begin{abstract}
This investigation has the purpose to analyze the relationship between the XixováJapuí State Park (PEXJ) and the Japuí district community in the city of São Vicente. Data regarding environmental perception, relationship with the local territory, knowledge and disponibility of information about the PEXJ were obtained directly from the community, the park managers and members of "SOS Itaquitanduva" NGO by semi-structured interviews. Additionally, historical-temporal narratives with aged people were obtained to provide data about Japuí district formation and evolution, based on the local community memory. Interviews were made with different stakeholders, to provide additional and related data. The analysis revealed that Japuí district is poor in its majority and its residents have low degree of study. Furthermore, the community history shows that the district was formed in the absence of Public Policies, i.e., the actions taken by the public power were not capable to attend the local demands. Once the community was not included in the management, its relationship with the park's administration has become very weak and based on lack of information exchange. The park managers did not have success in involving the neighbors in the park management and, consequently, Japuí's residents have low know ledge and interest on the park. This situation creates secondary problems, as conflicts between some stakeholders (specially the local NGO) and the park administration, as well as produces a scenario where the management is not participative.
\end{abstract}

Keywords: Protected Area, Xixová-Japuí State Park, socio-technique net, neighbor community 


\section{INTRODUÇÃO}

Como conseqüência de modelos de desenvolvimento que levam à exau stão e destruição dos recursos naturais, as preocupações relativas ao meio ambiente e sua conservação vêm sendo uma constante nos círculos de debate e nas agendas internacionais governamentais, bem como em meio à comunidade científica e sociedade civil. Tal preocupação é observada principalmente neste novo século no qual observamos, mais nitidamente e conscientemente, que se trata de questões que afetam a todos (Queiroz et al., 2004).

De acordo com Queiroz (2003), desde o século XIX já se observava que o homem atentava para as questões de cunho ambiental, mas a intensificação e o reconhecimento da comunidade internacional quanto a estas questões ocorrem, de fato, no século XX. No panorama mundial, as iniciativas a respeito dessa temática iniciam-se na década de 70. O Clube de Roma, um dos primeiros marcos a tratar do meio ambiente realizado em 1972, deu origem ao estudo intitulado "Limites do Crescimento". Tal estudo apontava a necessidade de alcançar a estabilidade econômica e ecológica, propondo o congelamento do crescimento populacional e do capital industrial (Brüseke, 1994). Ainda em 1972 aconteceu a "Conferência das Nações Unidas sobre Desenvolvimento Humano" (Conferência de Estocolmo). Seu foco principal situava-se em discussões sobre o ambiente humano e os impactos decorrentes dos processos de crescimento econômico aos quais estava submetido tal ambiente (ONU, 1972). Com o passar dos anos outras iniciativas relativas ao meio ambiente aconteceram, podendo ser citadas a Conferência Intergovernamental sobre Educação Ambiental de 1977, a Convenção de Viena para a Proteção da Camada de Ozônio, de 1985, e a Comissão Mundial sobre Meio Ambiente e Desenvolvimento, de 1987. Esta última originou o Relatório de Bruntland que faz considerações sobre questões políticas, econômicas, sociais e ambientais de maneira integrada, inserindo os princípios e critérios de sustentabilidade em pauta (Brüseke, 1994). Em decorrência desse relatório, a "Conferência das Nações Unidas sobre Meio Ambiente e Desenvolvimento" (Rio-92) promove a emergência do novo paradigma de sustentabilidade (Magalhães, 1994), tendo como um dos pilares de discussões o desenvolvimento sustentável. Como produto dessa conferência foram elaborados e assinados cinco documentos que tratam de assuntos relativos ao meio ambiente, 
dentre estes a Convenção sobre Biodiversidade, Convenção sobre Mudanças do Clima, Agenda 21, Princípios para Administração Sustentável das Florestas e a Declaração do Rio de Janeiro sobre Meio Ambiente e Desenvolvimento (Amaral et al., 2000). A continuidade de iniciativas como estas permitiu que o foco dado a conservação do meio ambiente passas se a ser cada vez mais evidente e abrangente, assim, a Cúpula Mundial sobre Desenvolvimento Sustentável (Rio+10) convocada em 2000 e realizada em 2002, teve como objetivo principal rever metas, implementar e refletir as conclusões e diretrizes obtidas na Rio-92, o que levaria à definição de um plano de ação global quanto ao desenvolvimento sustentável (Sequinel, 2002).

No Brasil uma legislação com normas específicas de proteção ao meio ambiente data do início do período da ditadura Vargas e do Estado Novo (1930/46), com a instituição do Código Florestal (Decreto $\mathrm{n}^{\circ} 23.793$, 1934), do Código das Águas (Decreto $\left.n^{\circ} 24.643,1934\right)$ e do Código de Pesca (Decreto-lei $n^{\circ} 704,1938$ ), prosseguindo sem alterações conceituais até o período da ditadura militar, entre 1964 e 1984 (Amaral et al., 2000).

Nas décadas de 70 e 80 o desenvolvimento de marcos legais nacionais direcionados à conservação do meio ambiente passa a ser mais expressivo, com a criação da Secretaria Especial do Meio Ambiente (SEMA) em 1973 (que posteriormente seria transformada no Ministério do Meio Ambiente - MMA) e, em 1981, do Sistema Nacional do Meio Ambiente (SISNAMA) constituído pelo Conselho Nacional do Meio Ambiente (CONAMA), Ministério do Meio Ambiente e Instituto Brasileiro do Meio Ambiente e dos Recursos Naturais Renováveis (IBAMA). Ainda na década de 80 destaca-se a instituição do Plano Nacional de Gerenciamento Costeiro (1988) e da Constituição de 1988, que foi a primeira Constituição brasileira a tratar deliberadamente da questão ambiental, sendo referida como eminentemente ambientalista (Silva, 2003).

Certamente a criação dos órgãos supracitados possibilitou a evolução do Brasil em respeito às iniciativas de ações voltadas ao meio ambiente, passando pelo desenvolvimento de programas, como o Programa Nacional do Meio Ambiente (PNMA) em 1987 e à discussões de âmbito internacional, como a já mencionada Rio-92.

Antes disso, as Áreas Especialmente Protegidas que posteriormente seriam chamadas de Unidades de Conservação (UC), já haviam sido legalmente 
implantadas no país, tendo como marco inicial a criação do Parque Nacional de Itatiaia em 1937 (Decreto $n^{\circ}$ 1.713). A criação desse Parque seguiu as disposições do Código Florestal vigentes na época, no entanto a legislação que regulamentou os Parques Nacionais só foi aprovada quatro décadas mais tarde, em 1979, sob o Decreto Federal $n^{\circ}$ 84.017. Tal iniciativa do poder público brasileiro refletiu a adoção de um modelo norte-americano para a conservação, uma vez que o conceito de Parques Nacionais como área natural protegida foi inicialmente empregada nos Estados Unidos ao final do século XIX, com a criação do Parque Nacional de Yellow stone em 1872 (Vallejo, 2003). Essa atitude pode demonstrar que a questão ambiental no Brasil ainda não era prioritária e quase não fazia parte da pauta política, o que pode ter culminado na falta de planejamento por parte do governo nacional da época em lidar com tal questão.

Apenas em 2000, a instituição do Sistema Nacional de Unidades de Conservação (SNUC) pela Lei $\mathrm{n}^{\circ}$ 9.985, estabeleceu critérios e normas para a criação, implantação e gestão das áreas protegidas no país (BRASIL, 2000). Disposições legais desse sistema definem que a criação de UC representa uma estratégia nacional para conservação in situ da biodiversidade.

De acordo com o SNUC, as Unidades de Conservação (UC) são definidas como espaços territoriais e recursos ambientais, incluindo as águas jurisdicionais, com características naturais relevantes, legalmente instituídos pelo Poder Público, com objetivos de conservação e limites definidos. A delimitação dessas áreas de proteção ao ambiente natural tem se mostrado, juntamente com outras alternativas, uma estratégia fundamental para a conservação dos ecossistemas e para a manu tenção da qualidade de vida do homem (IBAMA \& WWF, 2007). Sabendo que o Brasil abriga a maior diversidade biológica do planeta, que atinge cerca de $13 \%$ do total mundial (Lewinsohn \& Prado, 2005) e boa parte dos recursos naturais existentes (Queiroz et al., 2004), deve-se dedicar especial atenção as Unidades de Conservação nacionais e, principalmente, a seus preceitos sócio-ecológicos. De acordo com Rylands e Brandon (2005) as UC são importantes para a proteção das três grandes regiões naturais do Brasil - a Amazônia, o Pantanal e a Caatinga - e dos dois hotspots de biodiversidade - a Mata Atlântica e o Cerrado.

As UC são classificadas, de acordo com a exploração dos recursos, em dois tipos: Unidades de Conservação de uso sustentável e de proteção integral. A primeira categoria prevê a exploração sustentável dos recursos, de modo a manter 
suas características, integrada à conservação do ambiente, já a segunda, de proteção integral, permite somente o uso indireto dos recursos, visando à preservação ambiental. Dentro dessas categorias existem diversas categorias de UC (Tabela 1) que diferem entre si quanto à conservação e/ou preservação de ecossistemas, presença de espécies nativas e/ou migratórias, ocorrência de sítios de beleza cênica, patrimônios históricos e culturais, restrições de uso, grau de ocupação humana, presença de populações tradicionais, propriedade do território, esfera de poder do órgão de criação e quanto ao caráter dos órgãos internos relacionados à gestão (BRASIL, 2000).

Tabela 1 - Categorias de Unidade de Conservação

\begin{tabular}{|l|l|}
\hline Unidades de Proteção Integral & Unidades de Uso SuStentável \\
\hline Estação Ecológica & Área de Proteção Ambiental \\
\hline Reserva Biológica & Área de Relevante Interesse Ecológico \\
\hline Parques Nacionais, Estaduais e & Florestas Nacionais, Estaduais e \\
Municipais & Municipais \\
\hline Monumento Natural & Reserva Extrativista \\
\hline Refúgio da Vida Silvestre & Reserva de Fauna \\
\hline & Reserva de Desenvolvimento Sustentável \\
\hline & Reserva Particular do Patrimônio Natural \\
\hline
\end{tabular}

Adaptado de Queiroz et al., 2004.

De acordo com o SNUC, os Parques Estaduais, Nacionais e Municipais são de posse do domínio público e têm como objetivo básico a preservação de ecossistemas naturais de grande relevância ecológica e beleza cênica. No Estado de São Paulo, dentre as unidades de proteção integral estaduais, que correspondem a pouco mais de 3\% do território, representando cerca de 794.569,38 ha (São Paulo, 1998 apud Oliva, 2003, p.1), os Parques Estaduais são os mais representativos (WWF-Brasil, 2008). O uso do território abrangido por este tipo de UC é restrito à pesquisas científicas, ao desenvolvimento de atividades de educação e interpretação ambiental, de recreação em contato com a natureza e de turismo ecológico (BRASIL, 2000). Essas atividades permitidas junto à preservação de ecossistemas demonstram a importância não só ecológica de um Parque, mas também científica, educacional e social. 
Além das citadas restrições de uso, estão previstas normas específicas que regulamentam a ocupação e o uso dos recursos nas adjacências dos Parques, perfazendo uma área caracterizada como zona de amortecimento. As atividades previstas tanto para a área interna do Parque, quanto para a zona de amortecimento dependem de medidas estabelecidas no Plano de Manejo da unidade (BRASIL, 2000).

O Plano de Manejo é definido como o documento técnico mediante o qual, com fundamento nos objetivos gerais de uma UC, se estabelece o seu zoneamento e as normas que devem presidir o uso da área e o manejo dos recursos naturais, inclusive a implantação das estruturas físicas necessárias à gestão da unidade. Este documento deve incluir medidas com finalidade de promover a integração do território dos Parques, e suas áreas relacionadas, à vida econômica e social das comunidades vizinhas (BRASIL, 2000). Sendo assim, a obrigatoriedade do Plano de Manejo tende otimizar a gestão efetiva das UC e subsidiar a participação da sociedade civil nessa gestão, a chamada gestão participativa.

$\mathrm{A}$ inserção da comunidade local nos assuntos relativos às Unidades de Conservação também é prevista pelo SNUC antes da implementação do Plano de Manejo, no ato de criação da UC. A execução de uma consulta pública a respeito da criação da unidade, que forneça informações adequadas e inteligíveis à população local e a outras partes interessadas, se faz obrigatória, exceto para criação de Estações Ecológicas ou Reservas Biológicas. Além disso, o próprio SNUC, em suas diretrizes, constantes no artigo $5^{\circ}$, prevê que:

I. Sejam assegurados os mecanismos e procedimentos necessários ao envolvimento da sociedade no estabelecimento e na revisão da política nacional de Unidades de Conservação (inciso II);

II. Seja assegurada a participação efetiva das populações locais na criação, implantação e gestão das unidades de conservação (inciso III);

III. Sejam incentivadas as populações locais e as organizações privadas a estabelecerem e administrarem Unidades de Conservação dentro do sistema nacional (inciso V);

IV. Sejam consideradas as condições e necessidades das populações locais no desenvolvimento e adaptação de métodos e técnicas de uso sustentável dos recursos naturais (inciso IX).

O Conselho Consultivo é outro dispositivo de gestão das UC de proteção 
integral que leva em consideração a gestão descentralizada. Este é definido como o órgão voltado a consolidar e legitimar o planejamento e a gestão participativa, sendo uma de suas atribuições acompanhar a elaboração, implementação e revisão do Plano de Manejo (São Paulo, 2005). Levando em consideração a efetividade de um processo participativo, a instituição desse órgão é extremamente importante para legitimar as decisões e estabelecer fluxos horizontais de poder e discussão. Tal importância decorre do fato de que os integrantes desse conselho devem ser representantes de diferentes segmentos públicos e da sociedade civil atuantes na área de influência da UC e que todos os membros têm o mesmo peso de voto sobre as decisões. Além disso, o Conselho Consultivo tem o dever de facilitar a conciliação entre u so público e conservação (BRASIL, 2000). Deste modo percebese que a participação popular efetiva decorre muito mais da implantação do Conselho Consultivo, que apresenta alto potencial em cumprir algumas das diretrizes supracitadas do SNUC, do que da convocação de Consultas Públicas.

Felizmente, considerações sobre a participação popular não ficam restritas ao escopo legal ou às instituições governamentais quando se referem às Unidades de Conservação. Muitos pesquisadores do meio acadêmico e científico fazem considerações sobre e trabalham com base em processos participativos. Para De La Maza (1994) os fatores mais importantes integrando o processo participativo são a oportunidade de expressão aos diferentes setores, o tratamento com respeito e a existência de informações e regras de participação claras e explícitas. Lutgens (2000) afirma que o relacionamento da UC com a região que a insere é fundamental para o sucesso ou insucesso de seu manejo. Sobre tal sucesso Diegues e Moreira (2001) também destacam que, além do manejo, a gestão dos recursos naturais em UC tem apresentado notável eficácia quando diferentes setores agem de forma integrada.

Sobre o processo participativo Vieira et al. (2005) destacam que seu sucesso relaciona-se com diversos conhecimentos sobre as unidades biológica, sociológica e espacial das UC e seu entorno, sobre as políticas públicas direcionadas à gestão dos recursos, além de sobre os atores e sua relação com tais recursos. É importante ressaltar que a interação obtida com base em um plano participativo traz benefícios tanto para a UC, a respeito da gestão e manejo da área, quanto para a comunidade, no que concerne ao bem estar social, cultural e econômico. Ainda de acordo com Vieira et al. (2005) para que a comunidade se apresente apta em desfrutar de tais 
benefícios, esta deve assistir a um cenário de descentralização de poder, no qual a autoconfiança e a autonomia comunitária reforçam-se.

A implantação de certas ações de gestão em algumas UC pode ser tomada como exemplos em que os preceitos sócio-ecológicos tendem a ser cumpridos, proporcionando benefícios para todas as partes envolvidas, como foi o caso do Programa Integrado de Ecoturismo desenvolvido pela administração do Parque Estadual da Serra do Mar (PESM), núcleo São Sebastião, em parceria com o governo municipal de São Sebastião e a Petrobrás. Neste programa equipes de fiscalização ambiental municipal foram formadas para atuar como guarda-Parques. Tal iniciativa beneficiou a comunidade local, uma vez que este serviço de monitoria era de procedência dessa comunidade, além de beneficiar ao Parque, pela otimização do embargo de obras no interior da unidade e pelo controle da visitação (Cunha, 2002; Amaral, 2004). Deste modo este programa é um exemplo de gestão que permitiu atender às expectativas, não só sobre o âmbito ecológico, mas também o sócio-econômico.

Os processos de interação entre a comunidade e as Unidades de Conservação propiciam o aumento do entendimento da primeira sobre uma UC e suas importâncias ecológicas, sociais e econômicas. De posse de maior consciência sócio-ambiental, uma postura ambiental mais abrangente e real passa a ser assumida pela comunidade, que tende a defender o território e os interesses da área de proteção, participando ativamente dos processos de gestão e manejo. De acordo com Borrini-Feyeranbend (1997) inúmeros textos enfatizam que a participação nesses processos é um mecanismo capaz de compatibilizar os conflitos entre as UC e as comunidades locais, estejam elas dentro das áreas ou em suas proximidades. Para Simon (2004) conflitos são os comportamentos que causam ou possam causar danos aos objetivos básicos de conservação, decorrentes das atividades humanas que afetam ou podem afetar o uso das $\mathrm{UC}$ e as reações advindas dos atores sociais quanto a estes danos.

Exemplos de conflitos sócio-ecológicos são encontrados na literatura e demonstram a divergência de interesses entre comunidades de entorno e Unidades de Conservação. Para Lewis (1993) as características de tais conflitos devem ser entendidas e avaliadas, de modo que, dentro dos interesses tanto das populações quanto da UC, haja uma estratégia de ação que vise sua resolução.

Gomes (2002) relata a existência de conflito sobre o uso da terra, 
principalmente entre duas comunidades de entorno e o Parque Nacional da Serra da Bocaina (PNSB). Esse conflito traz impactos negativos para a área do Parque no que diz respeito à con servação da mata ciliar. De acordo com a autora essa situação deve-se à ausência de diálogo entre os envolvidos, uma vez que os limites físicos entre o PNSB e as comunidades de entorno apresentam controvérsias desde a criação desta UC. Oliveira (2005) destaca, entre outros, conflitos relacionados à conservação e preservação do Parque Estadual da Serra do Tabuleiro, decorrentes de atividades agrícolas desenvolvidas em regiões adjacentes ao território desta UC. Tais atividades levam à intensa drenagem de agrotóxicos, através de rios, para o interior do Parque. Para estes conflitos foram apresentadas sete causas possíveis, "imaginário" popular negativo sobre o Parque, descaso político com o Parque, descomprometimento da comunidade científica, descaso dos ambientalistas, limitação do desenvolvimento municipal, falta de informações sobre o Parque para a população e indefinição com relação a procedimentos sobre a futura realocação da população.

Com base no apresentado até o momento, percebe-se que o relacionamento entre comunidade de entorno e uma UC abarca uma enorme abrangência de assuntos. Os mais relevantes pautam-se em preceitos legais, sociais, ecológicos e econômicos. Além de tal abrangência devemos considerar que as pessoas apresentam princípios e ações próprias, ambos mutáveis e que influenciam o meio no qual estão inseridas. Além disso, existe um órgão, regido por leis e que deve cumprir preceitos sócio-ecológicos, gerindo um território, o qual muitas vezes utilizados pelas pessoas. Deste modo é de se esperar que o relacionamento entre as comunidades de entorno, a administração e o território das UC seja bastante complexo e dependente de inúmeros fatores.

Na Baixada Santista, região cuja paisagem coberta por florestas tropicais sofre intensas transformações, desde sua colonização, as áreas legalmente protegidas abrangem Parques Municipais e Estaduais, Áreas de Proteção Ambiental, Áreas de Preservação Permanente e Áreas Naturais Tombadas (Afonso, 2006). Entre as UC de proteção integral desta região, destaca-se o Parque Estadual XixováJapuí, localizado nos municípios de Praia Grande e São Vicente (Figura 1), inserido na interface da zona urbana e recebendo influência de diversos vetores de pressão antrópica (Oliva, 2003). Esse Parque é também peculiar, pois não possui ainda implantadas algumas ferramentas de gestão, como programas de uso público e 
pesquisa, e tampouco possui alguma forma de gestão participativa. Essa dificuldade gerencial tem levado a problemas com a população do entorno do Parque, em especial os moradores do bairro do Japuí, situado no município de São Vicente.

A fim de reconhecer as relações estabelecidas entre a comunidade do bairro Japuí e a administração e território do PEXJ, entendeu-se ser importante ações direcionadas à verificação de pontos conflitantes entre as partes, envolvendo diagnósticos sobre falhas de comunicação, análise dos principais eventos pretéritos que causaram um possível distanciamento, a identificação de interesses congruentes e a análise da influência dos principais eventos internos e externos sobre as pessoas.

A análise de tal relacionamento foi bastante coerente e útil para levantar subsídios teóricos que direcionem a implantação de práticas de gestão participativa e mitigação de possíveis conflitos. Deste modo, a investigação deste projeto se fez importante, uma vez que, com um enfoque mais direto e claro, promoverá dados consistentes para orientar as proposições legais relativas à gestão e manejo participativos desta Unidade de Conservação. Além disso, a administração do Parque Estadual Xixová-Japuí manifestou-se favoravelmente ao desenvolvimento do mesmo, declarando-o importante para auxiliar no cumprimento de alguns preceitos básicos, tais como o desenvolvimento da Fase 2 do Plano de Manejo e formação do Conselho Consultivo. 


\section{OBJETIVOS}

\section{Objetivo Geral}

I. Analisar o relacionamento que a comunidade do bairro Japuí mantém com o meio ecológico e com a administração do PEXJ.

\section{Objetivos Específicos}

I. Caracterizar o conhecimento, a afetividade e a informação da comunidade em relação ao território do Parque, seus recursos, restrições, importâncias sócioambientais e seu conhecimento em relação à administração do Parque;

II. Reconhecer as práticas de gestão e manejo da administração do Parque;

III. Identificar possíveis conflitos existentes entre o PEXJ, entidades relacionadas e moradores do Japuí e reconhecer suas principais causas; e

I5. Analisar o aspecto histórico que leva ao relacionamento atual. 


\section{MATERIAL E MÉTODOS}

\section{1.Área de Estudo}

\subsubsection{Parque Estadual Xixová-Japuí}

O Parque Estadual Xixová-Japuí possui 901 hectares, sendo 600 ha em terra e 301 ha em faixa marítima, distribuídos nos municípios de São Vicente e Praia Grande (Figura 1). Esta unidade insere-se num contexto ambiental de relevante interesse para a conservação da biodiversidade, uma vez que abrange uma porção de Mata Atlântica bastante conservada, que engloba diferentes ecossistemas, como matas de encosta, restingas, costões rochosos e praias arenosas. Sua criação pelo Decreto Estadual $\mathrm{n}^{\circ} 37.536$, de 27 de setembro de 1993, tem como principal objetivo proteger o patrimônio histórico e ambiental do território, considerando que a área apresenta alto potencial para realização de atividades de educação ambiental, podendo ser direcionadas à mitigação de problemas decorrentes de ações antrópicas, como, degradação ambiental, ocupação irregular e especulação imobiliária. O PEXJ resguarda uma porção reduzida de território legalmente protegido, cujo uso é indireto, e encontra-se numa região onde o grau de metropolização é bastante avançado (São Paulo, 1997).

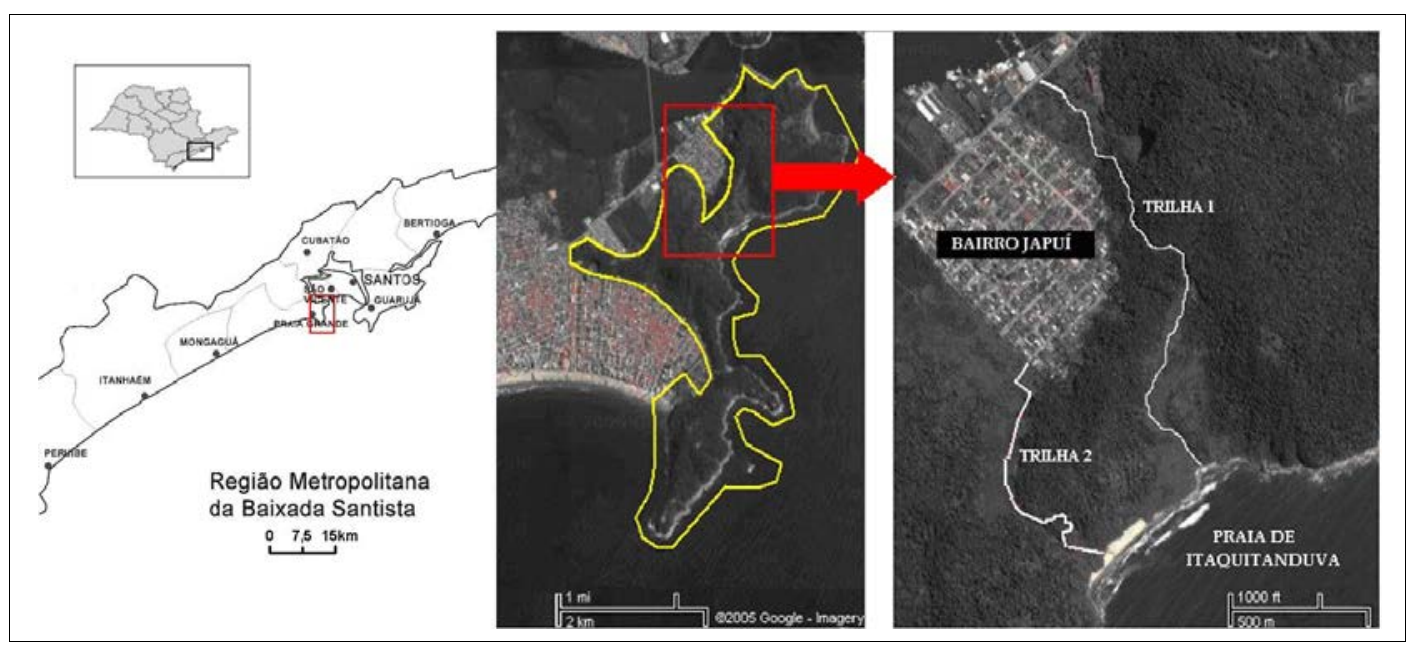

Figura 1 - Localização do Parque Estadual Xixová Japuí (Amarelo), com detalhe para o Bairro Japuí. Fonte: Google Earth

O acesso ao território do Parque, a partir da capital do estado de São Paulo, é feito através da Rodovia dos Imigrantes, que chega à Praia Grande próximo à Avenida Ayrton Senna, a qual segue em direção a São Vicente e passa junto ao 
limite do Parque, na Av. Tupiniquins. A partir do município de São Vicente, passando a Ponte Pênsil já se encontram os limites do Parque, que seguem com acesso a Av. Ayrton Senna (São Paulo, 1997).

O gradiente de altitude do Parque varia do nível do mar até 293 metros (Morro Xixová). Os vários morros que integram o território constituem pontos culminantes de um maciço rochoso datado do pré-cambriano, cercado pela planície litorânea formada por sedimentos do quaternário. Sua cobertura vegetal é principalmente constituída por Floresta Ombrófila Densa Atlântica Sub-Montanha e de Terras Baixas e em menor proporção vegetação de restinga e vegetação de encosta (São Paulo, 1997).

Dentre os aspectos históricos, o Parque e sua paisagem remetem à chegada das primeiras naus a São Vicente, considerada a primeira vila do Brasil, aos primeiros processos industriais do país (São Paulo, 1997) e a acontecimentos históricos tais como a Revolução de 1932 (comunicação pessoal, Sr. Fernando Licht). Suas edificações, que datam do final do século XIX, indicam o início da industrialização, ainda incipiente, na região da Baixada Santista.

O território do Parque é constituído por terras da União, da Fazenda do Estado de São Paulo e de particulares. Parte das terras da União foi cedida ao Ministério do Exército, onde são desenvolvidas atividades relacionadas à Fortaleza de Itaipu, e parte das terras do Estado foram doadas à União, com encargos, onde existiam instalações da Marinha do Brasil (São Paulo, 1997). Estas instalações foram recentemente cedidas à administração do Parque, onde são mantidos vigias e a diretoria da unidade. Ainda hoje não foram resolvidos os processos de desapropriação fundiária, sendo que extensas áreas do Parque ainda pertencem a particulares.

Para efeitos de planejamento e gestão, o território do Parque exibe uma setorização que visa otimizar o manejo junto às especificidades de cada área, sendo esta, Setor Paranapuã, Setor Curtume e Itaquitanduva, Setor Xixová, Setor Itaipu e Setor Costão e Mar. Em relação à região de seu entorno, área que se estende dos limites do Parque por um raio de $10 \mathrm{~km}$, assim como determina a resolução CONAMA $n^{\circ} 13 / 90$, considera-se haver a necessidade da adoção de critérios para o licenciamento de empreendimentos e obras de modo que os atributos paisagísticos da unidade sejam resguardados. A região de entorno baseada nessa resolução não é efetivamente instituída no PEXJ, uma vez que áreas adjacentes à unidade são zonas 
urbanas já consolidadas e a determinação de critérios de usos sobre tais zonas tornam-se mais difíceis, deste modo praticamente não há uma zona de amortecimento.

A análise preliminar sobre a ocupação da terra e vetores de pressão ambiental em cada um dos setores do Parque evidencia que as principais atividades impactantes são a visitação pública sem controle, a caça, a retirada de espécies vegetais e a pesca de arrasto (São Paulo, 1997). A ocorrência dessas atividades mostra a importância em integrar a população do entorno nos as suntos relativos ao PEXJ, de modo a conscientizá-la sobre a importância dos atributos ambientais e históricos da UC e tornar a gestão e manejo da área um processo democrático.

\section{2 . Bairro Japuí}

De acordo com a lei complementar $n^{\circ} 216$ da prefeitura de São Vicente, o bairro Japuí começa no cruzamento da linha divisória entre os municípios de São Vicente e Praia Grande com a Ponte Deputado Esmeraldo Tarquínio e com a orla do Mar Pequeno, junto à Avenida Tupiniquins, e segue por esta até a Ponte Pênsil; deflete à direita e segue pela orla da praia, junto à Prainha, contorna a orla da praia, passando pela Praia de Paranapuã, segue pela orla da praia contornando o Morro Japuí ate o cruzamento com a linha divisória entre os municípios de São Vicente e Praia Grande; deflete à direita e segue por esta até o ponto de partida.

Para o presente trabalho não foi considerada como área de análise a região do Parque Prainha, a partir da deflexão à direita da Ponte Pênsil citada acima. Esta região é considerada, tanto pelos moradores quanto pelo gestor da unidade, como uma porção distinta do restante do território descrito como pertencente ao bairro Japuí. Oliva (2003) em seu trabalho que aborda o entorno do PEXJ, também classifica como bairros diferentes o Parque Prainha e o Japuí. Essa diferenciação mostra a necessidade de abordagens distintas em trabalhos sócio-ambientais com a essas comunidades, bem como no desenvolvimento de programas do PEXJ. O trecho da Avenida Tupiniquins que faz a ligação entre os "bairros” Japuí e Prainha não foi considerada por ser prioritariamente ocupada por marinas. Deste modo a área analisada foram os loteamentos denominados como Jardim Bechara, Belvedere Mar Pequeno e Jardim Recanto de São Vicente, genericamente denominados Bairro Japuí (Figura 2), que conta com menos de 5230 moradores, uma vez que este número, obtido junto a Prefeitura de São Vicente, refere-se também ao Parque 
Prainha.

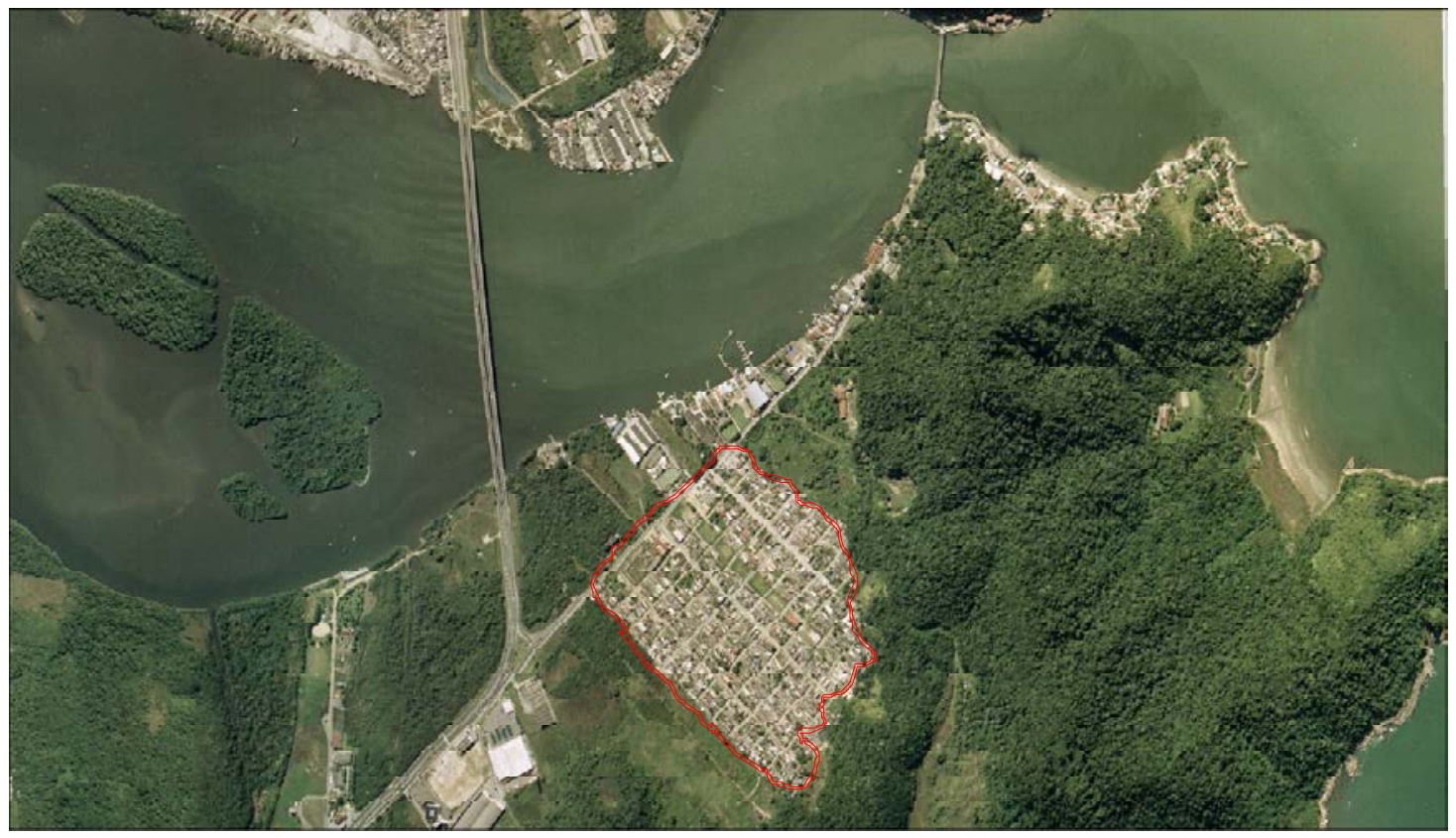

Figura 2 - Limites da área de estudo, Bairro Japuí. Acervo Fotográfico Digital UNESP-CLP: doação Polícia Ambiental do Guarujá

Na região do bairro, de acordo com Oliva (2003), são encontradas apenas casas térreas ou com até dois pavimentos, predominando a autoconstrução e não havendo prédios comerciais e residenciais. Os sistemas de abastecimento de água e de coleta de esgoto, bem como a coleta de lixo periódica e linha de distribuição de energia são presentes no bairro, que é caracterizado por esta autora como de baixa renda.

\section{3.Procedimento Metodológico}

Para a obtenção dos dados foram utilizados três questionários diferentes, direcionados aos moradores do bairro Japuí, aos membros da ONG "SOS Itaquitanduva" e ao gestor do Parque Estadual Xixová-Japuí.

O primeiro questionário, organizado de maneira semi-estruturada com 29 questões abertas e/ou fechadas e dividido em cinco blocos, foi elaborado com base em pré-testes aplicados junto à alguns representantes da comunidade e em informações obtidas durante conversas informais com o gestor do PEXJ. Este questionário foi aplicado junto aos principais representantes da comunidade do bairro Japuí, os quais foram indicados pelo gestor da unidade, seguindo-se a utilização do Método Bola de Neve (Biernacki \& Waldorf, 1981 apud Pieve et al., 
2006) no qual ao final de cada entrevista pedia-se que o morador indicasse outra pessoa para responder ao questionário. Esta metodologia não foi utilizada durante toda a coleta de dados, uma vez que as pessoas indicadas eram sempre do mesmo convívio, o que poderia enviesar os resultados obtidos, a partir disso o esforço amostral foi direcionado para diferentes "segmentos" da comunidade, dentre estes trabalhadores do comércio e de escolas e moradores de distintas ruas (para estes ainda foi utilizada a Metodologia de Bola de Neve). Foi entrevistado um total de 30 moradores do dia 26/04/2008 até 26/08/2008.

$\mathrm{O}$ primeiro bloco do questionário refere-se à caracterização e perfil do morador (perguntas 1 a 5, 26 e 27). O nome do entrevistado foi solicitado, no entanto esclareceu-se que não seria utilizado na redação do projeto visando preservar as pessoas quanto às informações cedidas. $\mathrm{O}$ segundo bloco de questões direciona-se a caracterizar o relacionamento dos moradores com o território do Parque (perguntas 6, 7 e 8). O terceiro aborda aspectos de informação ambiental dos entrevistados sobre o território do Parque (perguntas 9, 10 e 16 a 19). O quarto bloco foi sobre o conhecimento relativo ao Parque, enquanto uma Unidade de Conservação e sobre a disponibilidade de informações (perguntas 11 a 15, 20 e 21). O quinto e último bloco é composto por perguntas de opinião, fundamentadas em uma classificação qualitativa multicategórica. Estas questões abordam principalmente aspectos relacionados à gestão do PEXJ (perguntas 22 a 25, 28 e 29) (Anexo 1).

O questionário aplicado aos membros da ONG (três entrevistados) manteve a mesma estrutura do aplicado aos moradores para permitir a comparação entre as respostas, entretanto algumas questões foram modificadas, suprimidas ou adicionadas visando adaptar questionário quando necessário. Foi inserido um sexto bloco (perguntas 28 a 30), cujas questões foram relativas à caracterização da ONG. O questionário direcionado aos membros da ONG conta com 30 questões (Anexo 2) e todos foram aplicados no dia 26/07/2007. Algumas respostas tanto deste questionário quanto do aplicado aos moradores foram agrupadas em categorias para facilitar a análise dos dados.

Para o diretor (Sr. Eduardo Lourenço) foi elaborado um questionário organizado de maneira semi-estruturada com 17 questões abertas (Anexo 3). Este é composto por dois blocos, o primeiro direciona-se a reconhecer o ponto de vista do gestor em relação à participação popular (perguntas 3 a 10) e o segundo (perguntas 
11 a 17) seu ponto de vista relativo à comunidade e ao relacionamento que esta mantém com o território do Parque. A aplicação deste questionário ao gestor da unidade foi feita no dia 11/08/2008. Para esses três questionários as repostas foram adquiridas por meio de transcrição das mesmas, no momento da aplicação.

Foram tomados relatos históricos junto a elementos-chave da comunidade, neste caso foram seis moradores antigos do bairro, identificados durante a execução do projeto e por meio do Método Bola de Neve. Estes relatos tiveram como objetivo enriquecer a análise do relacionamento e visualizar dados marcantes percebidos pelos moradores sobre a evolução do bairro e do PEXJ, por exemplo, em relação à evolução demográfica e aos recursos naturais e seus usos. Pediu-se a permissão para gravar os relatos históricos, sendo que todos os moradores permitiram. A aquisição desses dados ocorreu entre 16/07/2008 a 25/08/2008.

Foi realizada uma entrevista com o supervisor da Regional do Bairro, direcionada a obter dados sobre o bairro, reconhecer a interação entre esta entidade e o PEXJ e as atividades desenvolvidas pela regional. A aquisição de dados junto ao supervisor ocorreu no dia 15/07/2008. Esta entrevista não foi gravada e a aquisição dos dados se deu por transcrição das repostas.

Adicionalmente foram tomados relatos com um representante do meio acadêmico e freqüentador do Parque desde o final da década de 80 (Dr. Denis Abessa), com o Coordenador Regional do Litoral Centro do Instituto Florestal (Sr. Júlio Vellardi) e com o his toriador do Centro Histórico e Geográfico de São Vicente (Sr. Fernando Licht), todos com o objetivo de obter informações sobre a evolução temporal da área de estudo e sobre sua gestão. A entrevista com o coordenador foi gravada com sua permissão, o que não ocorreu com os outros dois apenas por falta de condições práticas de gravação, sendo assim foi realizada a transcrição das respostas concedidas. Estas entrevistas foram realizadas em 21/08, 02/10 e 08/10, respectivamente. Os dados obtidos por meio dos questionários, relatos e entrevistas foram complementados com o levantamento de dados bibliográficos.

\section{4 . Análise de dados}

Os resultados foram analisados em relação à evolução cronológica do bairro Japuí e do PEXJ, abordando seu território, administração e o perfil dos moradores e 
dos membros da ONG "SOS Itaquitanduva”.

O relacionamento mantido entre as entidades analisadas foi definido com base nos resultados obtidos, principalmente os que demonstraram possíveis causas de conflitos e em relação aos preceitos sócio-ecológicos e administrativos de uma Unidade de Conservação da categoria Parque.

A evolução das políticas públicas incidentes no entorno foi analisada por meio do referencial teórico de Avaliação de Políticas Públicas, seguindo o proposto pelo CONSEIL SCIENTIFIQUE DE L'EVALUATION (1996). Este referencial, de acordo com Silva et al. (2007), constitui um quadro teórico e metodológico que possibilita compreender a lógica de ação do poder público e os seus efeitos, entendidos como todo comportamento ou estado que é resultado da influência de algum aspecto da política.

De acordo com Baptista e Peixoto (1999) as políticas públicas são definidas como um conjunto de decisões formalizadas sobre um assunto de interesse coletivo, tal assunto é considerado importante e prioritário para o desenvolvimento social. Para Silva et al. (2007) tais políticas "emanam do poder público que as formaliza, legitima e controla".

A avaliação de políticas públicas consiste em avaliar seus efeitos e consequiências sobre as pessoas atingidas, além de compreender a lógica do seu funcionamento dentro do estado da sociedade. A análise deve ser feita quanto a coerência, eficácia, eficiência, impacto e pertinência.

- A coerência tem relação com a concepção e aplicação da política, verificando se os diferentes objetivos são coerentes entre si, ou seja, se foram disponibilizados os meios e recursos para a viabilização e execução da política.

- A eficácia diz respeito ao cumprimento dos objetivos almejados pela política, comparando estes objetivos aos resultados alcançados. Muitas vezes essa análise é dificultada pela impossibilidade de se relacionar os objetivos iniciais aos resultados.

- A eficiência avalia se os recursos financeiros foram bem utilizados, se os resultados da política correspondem aos gastos e às condições financeiras do órgão público. Este item não será avaliado pelo presente estudo, uma vez que tais dados não foram levantados nesse trabalho. 
- O impacto, ou efetividade, analisa se as consequiências gerais para a sociedade foram benéficas, sem deixar de considerar os impactos negativos, previstos ou não. Tais impactos não necessariamente faziam parte dos objetivos.

- A pertinência avalia se os objetivos da política têm relação e atendem à realidade e necessidade social, ou seja, se existia uma demanda social para a política pública.

Para a análise de políticas públicas não há diferença se os dados, ou indicadores, analisados são qualitativos ou quantitativos, uma vez que estes sejam pertinentes (CONSEIL SCIENTIFIQUE DE L'EVALUATION, 1996). Foram avaliadas as políticas públicas implementadas na área de estudo a partir da década de 60 , visto que a consolidação da ocupação deste território iniciou-se nessa época. Neste caso os indicadores para a análise foram menções feitas pelos moradores a respeito das políticas. Esta análise permitiu entender melhor o relacionamento mantido en tre a comunidade e o PEXJ.

Seguiu-se a recomendação de ações relativas a gestão, com base no relacionamento existente, para alcançar uma gestão e manejo participativos e o cumprimento de preceitos sócio-ecológicos do PEXJ. 


\section{RESULTADOS E DISCUSSÃO}

\section{4 . 1 . Histórico do desenvolvimento local}

\subsubsection{De 1500 a 1900}

O primeiro vestígio de indústria no Brasil instalou-se onde hoje é o bairro Japuí. Na primeira metade de 1500, Mestre Cosme Fernandes, degredado de Portugal, teria iniciado neste local o comércio de escravos, carnes, peixes, lenha e barcos de produção própria. Ainda no século XVI, em 1532, foi construído o primeiro Trapiche Alfandegário do Brasil, hoje conhecido como Porto das Naus, que mantinha atividades comerciais com inúmeros navios, sendo transformado em um engenho de açúcar em 1580 (São Paulo, 1997). Este local foi tombado pelo Conselho de Defesa do Patrimônio Histórico, Arqueológico, Artístico e Turístico (CONDEPHAAT) em 1977.

Ao final do século XIX, por volta de 1897, instalava-se, na encosta do Morro Japuí, o Curtume Cardamone. Sua instalação nesse local devia-se à proximidade com o manguezal, de cuja vegetação era extraído o tanino para o curtimento de couro, e à presença de inúmeras nascentes de onde era obtida a água (Macedo, 1992). Esse curtume é considerado uma das mais antigas indústrias do país e trouxe inúmeros benefícios aos moradores de sua vila própria e do bairro Japuí. Em relato sobre este empreendimento uma moradora do bairro desde 1970 mencionou o seguinte:

- "O curtume foi útil pra muita gente, para as pessoas que trabalhavam lá e estudavam através do curtume. Tinha clubes, campo de futebol, lazer, diversões, bailes para os jovens aos sábados, festa junina e carnaval. $O$ curtume na época era muito gostoso, muito bom."

\subsubsection{De 1900 a 1960}

Ainda no território que hoje pertence ao Parque, pouco depois da implantação do curtume foi inaugurada a Fortaleza de Itaipu, em 1903, localizada no município de Praia Grande cuja construção deveu-se à necessidade de proteger o porto de Santos (São Paulo, 1997). De acordo com o historiador Fernando Licht, do Centro Histórico e Geográfico de São Vicente, esta obra incentivou a execução do primeiro aterro da atual Avenida Tupiniquins, cujo objetivo foi ligar São Vicente à Praia Grande. Este historiador mencionou que até então apenas a região do curtume 
era aterrada, sendo assim, pode-se notar que a criação desta nova rua permitiu o início da ocupação e desenvolvimento de um bairro sobre o ecossistema do manguezal.

O término da construção da Ponte Pênsil em 1914, cujo objetivo era conduzir esgoto até o Morro Itaipu, facilitou o escoamento de toda a economia rural da região (Francisco, 2000) e a travessia para a área continental de São Vicente, além disso, favoreceu o processo de implantação de outros estabelecimentos ao longo da avenida. Do outro lado da ponte, nesta avenida, já estava instalado o Clube de Regatas Tumiaru desde 1912, o qual havia deixado suas instalações originais exatamente para que a ponte pudesse ser construída (SECRETARIA DE EDUCAÇÃO DE SÃO VICENTE, s/ano), a partir daí, segundo o historiador Fernando Licht, começaram a aparecer restaurantes e outros clubes náuticos nas redondezas, o que certamente favoreceu ainda mais o estabelecimento das pessoas no bairro. De acordo com dados obtidos junto a Prefeitura de São Vicente, a aprovação do loteamento Parque Prainha, o primeiro desta região, ocorreu em 1928, fato que demonstra a existência de um grau de ocupação antrópica que já exigia o loteamento do território.

\subsubsection{De 1960 a 1970}

Segundo Francisco (2000), São Vicente teve sua importância diminuída em relação ao município de Santos devido a fatores geográficos, como a deficiência de seu porto, situado no largo de São Vicente e colmatado por processos sedimentares. Deste modo, de acordo com esse autor, a ocupação de São Vicente foi menos acentuada quando comparada a ocupação de Santos, sendo que o primeiro município mantinha até 30 ou 40 anos atrás possibilidades de expansão urbana. Foi exatamente em 1960 que se aprovou o primeiro loteamento da área de estudo do bairro Japuí, Jardim Bechara, seguido pelo Belvedere, Mar Pequeno e Jardim Recanto de São Vicente, aprovados respectivamente em 1963 e 1965 (dados obtidos junto à Prefeitura de São Vicente).

Nesta época a principais atividades econômicas do bairro, de acordo com moradores entrevistados, eram as atividades do curtume juntamente com a agricultura de banana. Três moradores que residem no bairro desde o início da década de 60, afirmaram que havia fazendas, com plantações de bananas, de diferentes donos, as quais também foram loteadas, e sítios com plantações de coco, 
abacate, tang erina, limão, laranja e verduras para con sumo próprio e com criação de gado para venda de leite. Apenas algumas plantações de banana estavam na atual área compreendida pelo Parque. A existência dessas propriedades produtoras de banana também foi confirmada por meio de dados bibliográficos (SECRETARIA DE EDUCAÇÃO DE SÃO VICENTE, s/ano) e mostra que a comunidade apresentava características essencialmente rurais, mesmo com a presença do curtume.

No início da década de 60 a ocupação no Japuí era incipiente, havia poucas casas desde as primeiras ruas, próximas à avenida, até a atual rua 10, beirando as encostas do morro (Figura 3). De maneira geral o valor dos terrenos era baixo e aumentava gradualmente quanto mais próximos da avenida, fazendo com que as imediações dos limites do que hoje é o Parque Estadual Xixová-Japuí já fossem ocupadas. Os moradores eram em sua grande maioria vindos de outros lugares, tanto de outros estados, como Bahia, Pernambuco, Sergipe e Alagoas, como do interior de São Paulo, de outros municípios do Litoral ou ainda de outros bairros de São Vicente.

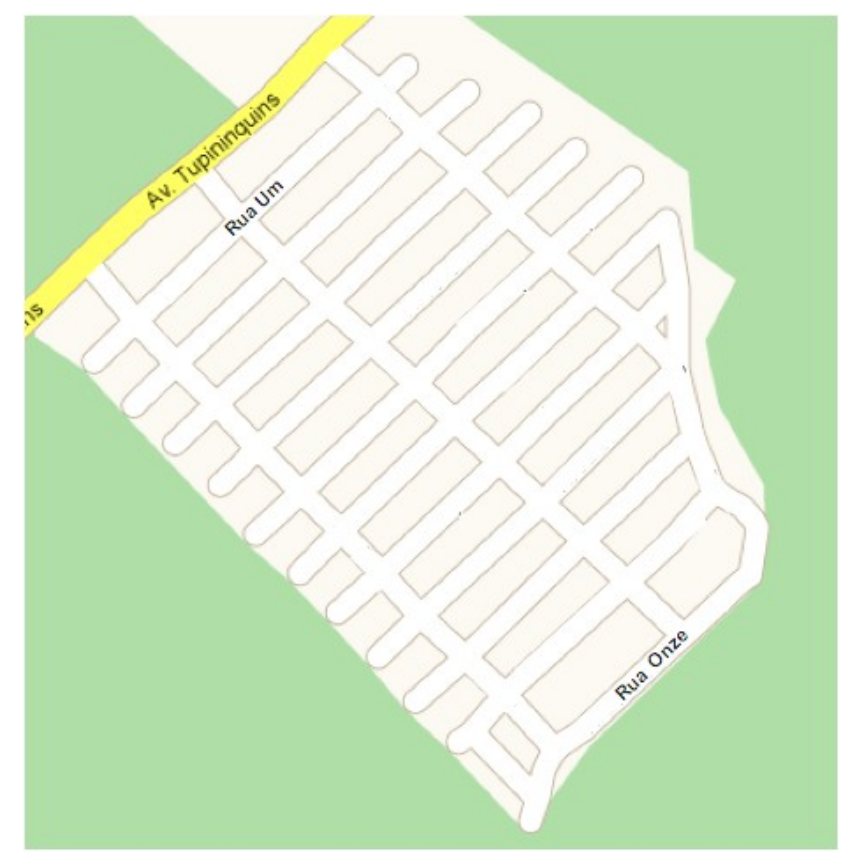

Figura 3 - Figura esquemática das ruas do Japuí. Fonte Google Earth

No bairro não havia ruas na região próxima ao morro, apenas picadas por entre os bananais, a luz era apenas de lampião e a água era adquirida da bica situada 
na atual rua onze, muitas pessoas tomavam banho e lavavam roupa nessa mesma bica. Pelo menos nas casas mais próximas à avenida (atualmente rua três) passava um caminhão pipa da prefeitura uma vez por mês, mas de acordo com uma entrevistada essa água sequer era suficiente para uma semana. Segundo os moradores o esgoto corria por valas a céu aberto e as "ruas" alagavam constantemente até onde hoje é a rua cinco. Uma entrevistada relaciona as condições precárias do bairro com a ocupação com a seguinte fala:

- “As pessoas evitavam morar aqui por que o esgoto era a céu aberto, aquilo lá era uma fedentina, eram pontinhas de madeira na porta, por que as valas passavam na calçada, quem é que queria morar aqui?"

Os moradores afirmaram que quando a maré subia ocorriam enchentes e para chegar até a avenida era preciso pegar um barco da atual rua 5 para que pudessem ir estudar no curtume. Além da escola do curtume havia uma segunda, Belvedere do Japuí, onde hoje está instalado a Unidade Básica de Saúde do bairro, apenas com o ensino primário (de $1^{\mathrm{a}}$ a $4^{\mathrm{a}}$ séries) e, de acordo com os moradores, era muito pequena e as crianças precisavam ir estudar na área insular do município. Esta escola foi construída com a ajuda de um dos donos das fazendas de bananas, Manoel Luiz Barreiros (SECRETARIA DE EDUCAÇÃO DE SÃO VICENTE, s/ ano).

Entre meados e o final de 60 os estabelecimentos existentes citados pelos moradores eram um bar na Av. Tupiniquins com a rua Caetano Cardamone, uma venda de onde se compravam os mantimentos e um posto de gasolina, ambos situados na mesma avenida e uma oficina. Dentre os locais no bairro que ofereciam emprego aos moradores estavam olarias, não mais que cinco, uma fábrica de caixotes de legumes e banana, situada em frente à atual Unidade Básica de Saúde na Av. Tupiniquins que encerrou suas atividades por volta de meados ou final de 1960. Nesta época, alguns clubes com o Yacht Clube São Vicente, também empregavam moradores do bairro principalmente após o declínio do curtume.

Entre o final de 1960 e começo de 1970 foi instalada a energia elétrica, que funcionava de forma bastante precária:

- "A luz era candeeiro de querosene, nós ficamos 4 anos nessa vida." (fala de um morador do bairro desde 1964);

- “A iluminação era péssima, bem fraquinha, os postes eram todos de 
madeira." (moradora do bairro desde 1970).

Sobre o processo de mobilização da comunidade para a aquisição de tal serviço uma moradora afirmou o seguinte:

- "Pra conseguir foi uma guerra, Brito Coelho veio fazer a primeira reunião na casa da minha mãe, ele foi se inserindo no bairro, mas não fez nada pro bairro." (fala de uma moradora a respeito da energia elétrica);

- “Nós fizemos panfletos e cartazes para reivindicar, no dia da passeata a prefeitura tirou os ônibus de circulação, mas nós fomos na prefeitura assim mesmo (...) não fomos atendidos, insistimos mais vezes e fomos atendidos.”;

O fato de a prefeitura ter suspendido as atividades do transporte público evidencia o descaso deste órgão pela comunidade do Japuí, fato que é agravado pela demora em atender as reivindicações sobre outros serviços públicos, assim como demonstram os seguintes relatos:

- "Depois de muitas reuniões correndo atrás do que era de direito, de prefeito, vereador, ai veio o calçamento."

- "Pra conseguir a escola do Estado a comunidade foi numa reunião em Peruíbe, levou uma carta para o secretário da educação pedindo uma escola, ai o prefeito não queria fazer."

- "Foram 11 anos de luta pra entregarem a primeira creche."

De acordo com o relato dado pelo Dr. Denis Abessa, o fato do bairro ser relativamente isolado dificulta ainda mais a tentativa de obter benefícios com a prefeitura, a qual parece ter um nível baixo de ação nesse e em outros bairros.

O fato de as reivindicações demorarem a ser atendidas, somado ao relativo isolamento do bairro, pode ser a causa da grande maioria dos moradores sempre se referir a região insular da cidade como "São Vicente", fazendo parecer com que não se sintam parte do município. A seguir falas de quatro moradores que demonstram esse sentimento:

- "As crianças tinham que estudar em São Vicente."

- “Eu trabalhava em Santos, saia daqui e ia a pé até São Vicente pra pegar ônibus lá.”

- "Tinha fila de um dia inteiro pra chegar em $\underline{\text { São Vicente." }}$

- "Ficamos estudando no grupão em $\underline{\text { São Vicente. }}$. 


\subsubsection{De 1970 a 1980}

O término das atividades do curtume foi entre o final da década de 70 e início de 80, em decorrência, de acordo com Macedo (1992), do fechamento do matadouro de Santos, principal fornecedor do couro utilizado. Uma moradora do bairro desde 1979 afirmou que quando chegou ao Japuí não tinha mais movimento no curtume, havia apenas bailes, mas a empresa não funcionava mais. Em relação ao encerramento das atividades desse estabelecimento duas moradoras afirmaram:

- "Na época que acabou o curtume foi difícil pra muitas pessoas, muita gente ficou sem emprego, o que salvou foram os clubes, o Baía, o São Vicente, o Jangada, deu muito emprego e dá emprego pra esse pessoal da Baixada."

- "Depois foram montando aqueles clubes, no meu tempo só o Yacht Clube que tinha, aí foi aumentando."

O Yacht Clube São Vicente está instalado na Avenida Tupiniquins desde 1962, o Clube Baia de São Vicente, instala-se nesta mesma avenida, desde 1967. O Clube Jangada não foi identificado neste estudo, podendo não existir mais. A criação desses e de outros clubes e marinas nesta avenida certamente possibilitaram a migração de parte da mão de obra, tanto na época que o curtume fechou, quanto em períodos posteriores. Cabe ressaltar que estes estabelecimentos funcionam até hoje sem licenças ambientais e provavelmente foram e continuam sendo agentes de intensa degradação ambiental.

No final da década de 70 as ruas ainda não eram asfaltadas, mas já haviam sido aterradas e tinham sido construídas comportas de modo que as enchentes não ocorriam mais. Um morador afirmou que por muitos anos o lixo vindo do município de Santos era jogado no bairro, o que trazia a necessidade constante de que os terrenos fossem aterrados. A energia elétrica era apenas de voltagem $220 \mathrm{~V}$ e o transporte público, assim como na década anterior, continuava passando somente na Avenida Tupiniquins. De acordo com os moradores a água encanada chegou entre o final de 1970 e início de 80, depois de tentativas da comunidade:

- "Para a água nos fomos com panela, balde, bacia, com roupa na cabeça, as crianças batendo lata, na frente da Sabesp da Antônio Emerich. Conseguimos água com essa luta."

Em 1979 a antiga escola, Belvedere do Japuí, foi transferida para a atual rua seis, passando a se chamar EMEIEF "Maria Mathilde de Santana" que tinha de $1^{\text {a }}$ a 
$4^{\mathrm{a}}$ série.

\subsubsection{De 1980 a 1990}

A atividade de vendedores ambulantes nas imediações da Ponte Pênsil foi proeminente por muitos anos, segundo uma moradora:

- "As pessoas viviam de vender na fila, que ia até a Praia Grande e além da Praia Grande."

O acesso à área insular de São Vicente era feita unicamente através desta ponte, sobre esse assunto algumas citações são interessantes:

- "Olha, para nós chegarmos em Santos 8 horas da manhã, a gente tinha que sair daqui as 4 e meia da manhã, você acredita?"

- “Quem vinha da Praia Grande, Mongaguá, Peruíbe, Itanhaém, ás vezes dormia aqui na estrada, eu morei na Praia Grande e tin ha que vir a pé de lá por que o transito não andava."

No início da década de 80 a atividade de comércio na fila da Ponte Pênsil praticamente desapareceu em decorrência da construção da Ponte do Mar Pequeno em 1980. A implementação desta obra obedecia aos processos da especulação imobiliária em áreas litorâneas da Baixada Santista. A construção desta ponte facilitou o acesso à Praia Grande, ao litoral Sul e ao Vale do Ribeira (Francisco, 2000), além de ter desobstruído o tráfego na região. Sobre tal construção os moradores afirmam que proporcionou inúmeras melhorias no Japuí, o que, aliado às obras públicas antecedentes e as novas e melhores condições no bairro surgidas posteriormente, certamente provocou um aumento da especulação imobiliária também no Japuí.

- "Isso aqui era empesteado de carro, aqui morria muita gente, por causa que não tinha duas pontes. Aí depois que o Paulo Maluf fez essa ponte melhorou $100 \%$ o Japuí.”

- “O povo perdeu o emprego e ganharam a liberdade de ir e voltar sem precisar ficar quatro, cinco, praticamente dez horas na fila pra chegar em São Vicente.”

- "Foi de 80 pra cá que foi melhorando tudo aqui no Japuí, por isso que os terrenos eram baratos, não tinha essa coisa de benfeitoria."

- "Depois da criação da Ponte do Mar Pequeno, até então era uma padaria 
que tinha aqui no bairro, o pronto socorro foi inaugurado só em 81.” (entrevistada comentando sobre a chegada do comércio no bairro).

- "Depois da construção da Ponte do Mar Pequeno o bairro aumentou, o comércio ambulante diminuiu e houve maior ocupação do mangue." (fala do Dr. Denis Abessa).

É importante ressaltar, mesmo que as falas acima demonstrem os benefícios que a Ponte do Mar Pequeno trouxe para o bairro Japuí, que tais efeitos foram apenas indiretos, considerando-se o real objetivo de tal empreendimento.

Ainda no início de 1980, precisamente em 81, foi inaugurado o primeiro e único posto de saúde do bairro. Os relatos demonstram que as ruas foram asfaltadas em meados de 1980 e, até então, de acordo com uma moradora, permaneceram por muito tempo com os resíduos industriais que eram trazidos da Cosipa e depositados no bairro, de acordo com sua fala:

- "Eles jogavam a escoria da Cosipa, subia uma poeira terrível preta, aquilo dava tosse na gente, os brônquios, o nariz ficava terrível. Os móveis, você limpava a casa de manhã e de tarde tinha limpar tudo de novo que ficava com aquela poeira preta, quando passava os caminhões pesados subia aquela poeira enorme."

Tal fato foi citado apenas por uma moradora e pode ser apenas uma confusão de idéias, no entanto caso seja verdade, assim como o descarte do lixo do município de Santos, fica demonstrado o descaso da prefeitura perante esse bairro e sua falta de planejamento, uma vez que ações como essas levam ao aumento de gastos públicos, por exemplo, com infra-estrutura na área e com saúde pública, não só dos moradores do bairro, mas também de áreas próximas aonde tais resíduos eventualmente cheguem por conta da drenagem do solo. A probabilidade do bairro ter sido aterrado com resíduos da Cosipa é aumentada quando observamos o histórico de abandono do poder público diante do Japuí ou mesmo quando consideramos outras políticas no território, como por exemplo a construção da Ponte Pênsil, cujo objetivo era levar esgoto proveniente de Santos ao atual município de Praia Grande.

Ainda nessa época, precisamente em 1986 foi inaugurada a segunda escola, E.E. "Antonio Luiz Barreiros", dessa vez estadual e com ensino médio apenas a partir de 1989. 


\subsubsection{De 1990 a 2008}

Apenas em 1997 foi criada a primeira creche do bairro, "Dr. Luiz Gonzaga de Oliveira Gomes" e em 2004 a segunda "Olinda Cury Gigliotti", estas são as únicas creches do bairro e ambas são municipais. Por volta de 2003 foi implantado o sistema de captação de esgoto, a partir de então o território permanece sem grandes mudanças. Os moradores afirmam que ocorrem muitas tentativas de construir casas nas encostas dos morros, mas eles próprios denunciam para o IBAMA ou Defesa Civil:

- “Os moradores sempre cuidaram bem dessa área aqui. Criou não uma lei, mas uma visão pra não ter favela, ninguém permitia favela e as pessoas que moram mais pra lá (próximo as encosta), eles não permitem favela e quando vê que tem alguém invadindo já ligam pra Defesa Civil pra que não exista."

Foi durante este período que o transporte melhorou no bairro. Esta melhoria também contou com manifestações feitas pelos moradores e resultou na entrada de condução no bairro, no entanto apenas por lotações e não por ônibus municipal. Ainda hoje a disponibilidade do transporte ocorre apenas até a meia noite. $\mathrm{O}$ fato do transporte no bairro ser feito apenas por lotações é apenas mais um indício da ausência de atuação do poder público. A seguinte fala é de uma moradora que participou das reivindicações:

- "Aí o ônibus não entrava aqui, nunca conseguimos ônibus municipal, as empresas não queriam ficar aqui por que não dava lucro, ai veio a opção da Alternativa pra São Vicente (lotação).”

Atualmente os problemas do bairro dizem respeito à segurança, ao transporte público, às condições do Posto de Saúde e, em menor proporção, ao comércio, assim como mostram as passagens abaixo:

- “(...) e polícia então pior, por que policiamento aqui só vem uma vez ou outra, o que precisava aqui era um posto policial que nos não temos.”

- "Agora o que tem que é terrível e não tinha antes é as drogas e ladrões."

- "Não temos mais confiança de ficar numa esquina por que só fica na esquina o grupo de adolescentes e jovens que são viciados, eles tomaram conta do bairro, principalmente da praça. A nossa praça, há uns 2 meses 
atrás era ponto de droga.”

- "Só tinha um ônibus que passava lá na pista, apesar que hoje é a mesma droga, sem essas peruas a gente morre.”

- "Hoje vivemos no céu, só que o duro aqui no bairro é a condução, aqui é muito ruim."

- Eu nunca vi um posto de saúde fechar de sábado e domingo, nós somos uma comunidade bem grande e quando fecha dos dois lados de automóvel, nós não temos pra onde correr."

- “Na UBS, não temos ambulância."

- “Aqui o que precisa era uma boa farmácia, um bom supermercado, tudo, por que não tem, nós vamos tudo pra São Vicente pra comprar.”

O bairro dispõe de uma Regional de Bairro, existente há três anos e vinculada ao vereador reeleito Dr. José Eduardo, que trata de assuntos referentes à administração urbana, como limpeza de bueiros e das ruas e desenvolve ações comunitárias, oferecendo à comunidade aulas de ginástica e artes marciais.

A ONG "SOS Itaquitanduva", cuja sede se localiza no bairro Japuí teve sua existência formalizada em 2000. Desde o inicio de sua criação, mesmo em estado informal, a ONG desenvolve atividades voltadas à conservação do PEXJ.

\section{4 . 2 . Histórico do território do Parque Estadual Xixová-Japuí}

Em parte do território que hoje pertence ao Parque, de acordo com os relatos feitos pelos moradores do bairro Japuí, havia plantações de arroz e banana. Ainda hoje existem áreas com remanescentes do cultivo de banana no PEXJ. Também foi relatada a ocorrência de criação de gado na região da Praia de Itaquitanduva. Esses relatos, assim como consta na fase 1 do Plano de Manejo dessa unidade, indicam que parte da floresta do Parque é secundaria em diferentes estágios de regeneração.

A área do Parque, na década de 60, início do desenvolvimento do bairro, era utilizada pelos moradores para práticas de lazer e para exploração de recursos, dentre estes caça, pesca, retirada de marisco e ostra, corte de palmito. Algumas dessas atividades eram alternativas de fonte de renda para pessoas da comunidade. Algumas citações relacionadas a tais práticas exploratórias:

- “Antes você via (caça), passavam na nossa frente com aqueles calangos grandes e raposa." 
- "Viviam da pesca, pescavam muito."

- "Ali (na praia de Itaquitanduva) a gente pegava muitos mariscos, o pessoal ia buscar de sacos, mariscos grandes, bonitos. Ia pescar, caçar, fazia mariscada com palmito...”

Uma moradora afirmou que aos sábados, durante a década de 70, sua família pegava marisco na praia de Itaquitanduva e fornecia a um restaurante situado na Praia Grande, de acordo com sua fala:

- "Meu pai tinha um compromisso de fornecer $20 \mathrm{~kg}$ de marisco por fim de semana pra esse restaurante."

Outro entrevistado afirmou que tomava conta de uma área que hoje pertence ao Parque, onde havia plantação de arroz e banana.

O uso do território para práticas de lazer entre as décadas de 60 e 70 era feito principalmente por moradores do bairro, que acampavam, passavam o dia na praia e comemoravam datas festivas, assim como demonstram as falas a seguir:

- "Nossa vida era essa, se divertia por lá (na praia de Itaquitanduva) com a família toda e de noite vinha pra casa."

- "A gente ia muito pro Itaquitanduva, acampava, passava natal, ano novo, carnaval, era muito bem cuidado.”

- "Antes era como se fosse privado para a comunidade, era como um condomínio.”

- “As pessoas tinham confiança, ficavam lá, dormiam, era tudo família."

Alguns entrevistados, dentre estes uma moradora e o Dr. Denis Abessa, deixaram claro que mesmo antes da criação do Parque havia fiscalização militar na área, o que acabava por inibir alguns crimes ambientais. De acordo com este último entrevistado na época em que os militares faziam a fiscalização esta prática era mais eficiente. É importante lembrar que neste período o país assistia a um cenário de ditadura militar, sendo que o objetivo da fiscalização era a segurança do território nacional e não a proteção do meio ambiente. Sobre tal assunto segue a fala da moradora:

- "Quem toma conta é o forte Itaipu, por que aí é tudo proibido, a pesca, quem vai pescar, caçar é preso, que eu saiba o pessoal só ia pra lá pra se banhar, só fazia isso, por que tava proibido tudo lá em cima. Quando eu mudei pra cá já era assim, pegar marisco, ostra e pescar era proibido, meu 
marido foi quase preso, mas pegavam tudo escondido." (moradora do bairro desde 1965).

Uma entrevistada que morava no território que hoje pertence ao Parque e saiu do local por volta de 1990, afirmou que desde essa época já atuava no Parque a ONG "SOS Itaquitanduva" que distribuía sacolas de lixo aos visitantes e fazia limpeza na praia. De acordo com ela haviam mais famílias que residiam no Parque, e sobre a presença de tais pessoas outra moradora afirmou:

- "Até mais ou menos 90, tinham pessoas que moravam no alto da serra, tomavam conta da passag em, controlavam direitinho."

Ainda de acordo com a ex-moradora do Parque a área já era freqüentada por usuários de drogas e a ocorriam atos violentos, assim como demonstra a fala de outra entre vistada:

- "E aí em cima também já mataram umas 6 pessoas."

De acordo com Dr. Denis, freqüentador da praia de Itaquitanduva desde o final da década de 80 , as pessoas que não moravam no bairro não utilizavam a trilha que sai do Japuí e dá acesso à praia. O motivo para que não utilizassem essa trilha era a alta incidência de violência. Ainda hoje em dia fala-se muito para os visitantes que não são da comunidade que as trilhas para Itaquitanduva são inseguras pela alta incidência de assaltos e alguns casos de mortes. As seguintes falas se referem à segurança atual do Parque:

- "Nós achamos ossada humana na trilha do Parque, crimes na entrada do Parque, muitos as saltos, muita droga, a entrada do Parque é especialmente pra fazer ponto de tráfico (...) uma criança foi morta perto da bica."

- "Hoje já não da mais pra ir e ficar a noite, eu tenho medo."

- “(...) depois alguns pais, eu mesma não freqüento mais pra acampar, para passar o dia todo.”

- “(...) então começou a mudar as coisas, aconteceram mortes, roubos, jovens fumando droga."

A tentativa de construir empreendimentos na área do Parque foi citada tanto por moradores que responderam ao questionário, quan to por moradores que deram entrevista sobre a história do bairro. Sobre tal assunto parece ter havido três momentos em que construções no Parque foram cogitadas. O primeiro deles remetese à construção de um condomínio, quando o Parque ainda não tinha sido criado, 
cerca de 20 anos atrás. Uma moradora afirmou que a tentativa de construção foi em 1986, e outro morador disse o seguinte:

- “(...) condomínio fechado, era pra fazer isso, mas o IBAMA embargou, está tudo pronto e está parado há uns 20 anos.”

A segunda tentativa, de acordo com o relatado pelos moradores data de dez a quinze anos atrás, de acordo com o mencionado por duas entrevistadas:

- “Iam construir um condomínio, parece que até passaram a maquina lá em cima (morro Japuí), mas não houve esse projeto mais não. Eu calculo há uns 10 anos atrás.”

- “Em 1993 que o seu Paulo Salin Maluf queria fazer um cassino lá (morro Japuí), com teleférico, vieram engenheiros ai medindo, fazendo os planos eu acredito que não vingou por que o IBAMA entrou no meio. Então foi feito lá em cima uma fábrica pra fazer blocos, mas acabou em nada e até hoje mora uma família lá nesse lugar da fábrica."

Em decorrência desse empreendimento houve mobilização da sociedade civil para que sua construção não ocorresse. De acordo com membros da ONG "SOS Itaquitanduva" este processo de mobilização contou com a participação de seus componentes da época. Essa informação não pode ser adquirida com tais pessoas por não fazerem mais parte de ONG e não freqüentarem o bairro, impossibilitando sua localização, seja por motivo de falecimento ou pela ausência junto às entrevistas marcadas. Uma relação que não pode deixar de ser feita é a construção da Ponte do Mar Pequeno, pelo então governador do Estado, Paulo Maluf e a sua posterior tentativa de construir um cassino na praia de Itaquitanduva. Não se pode afirmar que a construção da ponte já guardava intenções de implementação de tal empreendimento, no entanto o desenvolvimento de infraestruturas que ela trouxe ao bairro pode ter promovido as possibilidades necessárias para a construção do cassino. Outro fator que pode ter influenciado na tentativa de construção de tal empreendimento diz respeito à destacada beleza cênica da área do Parque, que certamente se converteria num atrativo diferenciado, de alto padrão, e com íntima relação ao público que freqüenta as marinas e clubes já instalados na área.

Consta na fase 1 do Plano de Manejo da unidade que organizações não governamentais locais tiveram influência para a criação do Parque, além disso 
membros da ONG "SOS Itaquitanduva" afirmaram que essa organização existe antes mesmo da criação do PEXJ, o que, como já mencionado foi reafirmado pela moradora que residia no território da unidade. Mesmo dispondo de tais dados não se pode afirmar categoricamente que foi a tentativa de implantação deste cassino, por volta de 1993, que culminou na solicitação pelo menos por parte da ONG pela criação do Parque.

Outra situação de tentativa de construir um condomínio aconteceu por volta de 2004. De acordo com uma moradora do bairro esta intenção partia de pessoas de fora do município, mas não foi executada em virtude das leis que protegem o Parque. Outra entrevistada também mencionou a tentativa de construção de tal condomínio e disse ter sido convidada para uma passeata, há três ou quatro anos atrás, relacionada a este empreendimento. Esta moradora não participou deste evento, sendo assim, as intenções da passeata não puderam ser confirmadas. É importante mencionar que esta tentativa de construção não foi mencionada pelo diretor do Parque ou pelo coordenador do IF além não ser do conhecimento do Dr. Denis Abessa e não ter sido encontrada em outras fontes de informação, como por exemplo, jornais de São Vicente. Deste modo esta informação pode ser equivocada e apenas uma confusão de idéias das moradoras, uma vez que o Parque já havia sido criado o que tornaria improvável a tentativa de tal empreendimento e a repercussão alcançada pelo mesmo.

A criação do Parque Estadual Xixová-Japuí, em 1993, assim como consta na fase 1 de seu Plano de Manejo, elaborada apenas em 1997, aconteceu como conseqüência dos seguintes fatores:

- Solicitações de diversos segmentos para a criação de uma área de proteção do patrimônio ambiental que abrangesse os morros Prainha, Japuí, Xixová e Itaipu. Tais segmentos eram na época o poder executivo e legislativo dos municípios de São Vicente e Praia Grande, Universidade Estadual Paulista, representada pelo Centro de Ensino e Pesquisa do Litoral Paulista, representantes regionais do Ministério Público do Estado e organizações não governamentais locais;

- Elevado grau de conservação deste fragmento de Mata Atlântica inserido na Baixada Santista e localizado à beira-mar;

- À grande variedade de ecossistemas presentes nesse território que agem no 
sentido de promover a manutenção da biodiversidade;

- Presença de áreas de pousio, reprodução e alimentação para espécies de aves migratórias, as quais devem ser mantidas pelo fato de grande parte da região litorânea do Estado de São Paulo apresentar-se descaracterizada, o que inviabiliza a permanência dessas espécies;

- Importância científica do território;

- Localização estratégica, quanto à inserção regional, para o desenvolvimento de atividades de educação ambiental;

- Ocorrência de aspectos históricos que remetem ao início da colonização do país;

- Necessidade de proteção legal da área com objetivo de contrapor pressões causadas tanto pela ocupação irregular, quanto pela especulação imobiliária. Em relação à época posterior à criação do Parque algumas menções dos moradores, quan to aos usuários da área e benefícios são interessantes:

- “Passou a ser mais popular e turístico. Depois o Parque foi divulgado, Itaquitanduva foi divulgada e começou a entrar surfista. Mudou bastante, virou um chamariz de surfistas, de gente."

- "Trazia mais benefícios (antes da criação do Parque) do que agora. Era peixe, o pessoal pescava bem, marisco e a tranqüilidade que as pessoas tinham quando estavam lá, isso não temos mais, você pode andar na beira da praia toda, pode subir nas pedras descer que não vê mais marisco, até os filhotinhos eles tiram da pedra."

- “Agora o Parque não traz mais nada (referindo-se aos benefícios), por que está parado, é uma obra completamente parada."

- “Mudou pra melhor, por que antes o pessoal derrubava a mata, punha fogo, jogavam muito lixo, agora não tem isso, então o meio ambiente que agradece."

É importante notar que há opiniões divergentes quanto aos benefícios da área antes e depois da criação do Parque. O PEXJ foi criado sem dispor de recursos humanos e infra-estrutura para sua implementação. De acordo com Sr. Júlio Vellardi, a gestão dessa unidade foi acumulada pelos funcionários do núcleo Itutinga Pilões, setor do Parque Estadual da Serra do Mar, cujo gestor era o próprio Sr. Júlio e manteve tal condição de 1993 até 1997. Tal situação demonstra a falta de 
planejamento do poder público para lidar com assuntos relativos ao meio ambiente, o que se não for contornado pela gestão da unidade logo após sua criação pode refletir a inoperância desta diante do cumprimento de seus objetivos, culminando no que se denomina "Parques de Papel". Este termo, de acordo com Lima (2005), se refere às UC que não foram realmente implementadas e têm apenas uma existência virtual, como linhas desenhadas em mapas oficiais. Este autor, discorrendo sobre a efetividade de manejo em Unidades de Conservação de Minas Gerais, afirma que o dirigente público deveria, à luz do direito e a bem da responsabilidade, ser responsabilizado pelos "Parques de Papel".

A respeito da criação do Parque algumas falas dos moradores são interessantes:

- "Não fui convidada, não participei. Talvez por que eu moro bastante distante do Parque, moro aqui perto da pista, a ONG é mais para pessoas aproximadas do Parque, deve ser por isso." Cabe ressaltar que essa moradora acredita que a administração do Parque é feita pela ONG "SOS Itaquitanduva".

- “Não fiquei sabendo não, só fiquei sabendo por que eu moro perto da entrada do Parque, quando vieram demarcar, por que aí vai conversar, pergunta e eu fiquei sabendo." Isso apenas em 1997 ou 1998, de acordo com a moradora, que pensou se tratar da criação do Parque, mas era apenas a demarcação de seus limites, uma das diretrizes presentes na fase 1 do Plano de Manejo.

Em 1997 foi nomeado um gestor para o Parque e a sede administrativa deste se instalava no Instituto de Pesca do município de Santos, localizado na Ponta da Praia. Durante essa gestão apenas duas pessoas integravam o quadro de funcionários do Parque, o próprio gestor e uma secretária. De 1997 até 2003 a direção foi assumida por este gestor e foi no início de sua gestão que foi elaborada a primeira fase do Plano de Manejo.

Esta fase do Plano de Manejo foi elaborada por técnicos do Instituto Florestal em conjunto com pesquisadores do extinto CEPEL-UNESP (Centro de Pesquisa do Litoral Paulista) e publicada em 1998. O principal objetivo desta fase foi fazer uma caracterização geral do território do Parque com base em dados disponíveis. Nesta fase constam diretrizes gerais que deveriam ser implementadas 
no Parque e em sua área de entorno, sendo estas:

- Conservação dos atributos naturais, históricos, culturais e paisagísticos que motivaram a criação do Parque;

- Recuperação de áreas degradadas;

- Demarcação das divisas do Parque em campo, incluído a instalação de marcos de concreto e placas de sinalização;

- Planejamento e desenvolvimento de ações de proteção através de trabalho integrado com a polícia Florestal e de Mananciais e órgãos públicos;

- Equacionamento e encaminhamento de soluções junto à Procuradoria Geral do estado objetivando a regularização fundiária;

- Estabelecimento de critérios e planejamento para divulgação do Parque nos meios de comunicação e também junto à comunidade de entorno;

- Implantação de programa de administração, equacionando a implantação de sede administrativa, equipamentos e outros itens;

- Inserir o PEXJ nas prioridades para busca de recursos através de parcerias e investimentos internacionais.

Neste documento foi previsto que a fase seguinte deveria dispor do estabelecimento de parcerias visando à gestão participativa do PEXJ. Sobre a participação da comunidade de entorno na fase 1 não há nenhum indício que tenha ocorrido, pelo menos quando se trata dos moradores do bairro Japuí, visto que nenhum dos entrevistados participou de reuniões ou eventos pelo órgão gestor do Parque. É importante mencionar que quando foi desenvolvida esta fase, não era previsto em lei a participação da sociedade civil. O Decreto $\mathrm{n}^{\circ} 84.017$ de 21 de Setembro de 1979 que regulamenta os Parques Nacionais Brasileiros, sequer faz menção sobre processos participativos, seja na implantação, gestão ou manejo dessa categoria de Unidade de Conservação. Entretanto, na época em que foi desenvolvida esta fase, inúmeros textos científicos já faziam menções sobre a importância da participação das comunidades nos processos de tomada de decisão relativos ao meio ambiente e seus recursos naturais (De La Maza, 1994; Brüseke, 1994; Sekiguchi \& Pires, 1994; Vieira, 1994 e Borrini-Feyeranbend, 1997).

A segunda fase do Plano de Manejo começou a ser elaborada em 1998, tendo sido concluída apenas em 2001, no entanto não foi aprovada pelo Conselho Estadual de Meio Ambiente (CONSEMA). O desenvolvimento dessa fase contou 
com a participação da comunidade civil em reuniões temáticas, contudo no presente estudo apenas o atual presidente da ONG disse ter sido convidado, por amigos, para participar de destas reuniões.

Ainda nesta fase estava prevista a implantação de um Comitê de Apoio à Gestão, formado por representantes de segmentos públicos e da sociedade civil e de caráter consultivo. Com a criação desse comitê objetivava-se agir de forma que as práticas de gestão e manejo da unidade fos sem participativas, inclu indo, portanto, as comunidades de entorno. De acordo com a fase 2 do Plano de Manejo, o Comitê de Apoio à Gestão seria implantado e a definição de seus membros aconteceria em reunião com representantes dos órgãos públicos e diversos segmentos da sociedade civil, que participaram das reuniões temáticas. Entretanto, não há nenhum indício de que este comitê tenha sido criado, o que, muito provavelmente, deve-se a não aprovação desta fase do Plano de Manejo.

Quando questionados sobre a efetividade do processo participativo da sociedade civil, principalmente das comunidades de entorno, no desenvolvimento das fases do Plano de Manejo, o gestor do PEXJ e o coordenador do IF responderam, respectivamente, o seguinte, relacionado com a elaboração da fase 2 , não aprovada:

- "Houve participação da comunidade firmada por vários segmentos da sociedade, inclusive civil. O envolvimento da comunidade é válido e será retomado na re-elaboração da fase 2 (...) será a base para processos futuros.”

- "Foi efetiva a partir do momento que o cara assinou o ponto e foi participar das audiências e oficinas. Se ela foi efetiva pra ajudar no resultado acho que não, por que a pessoa só pode participar e sugerir coisa pertinente se previamente ela estiver informada sobre o que se vai discutir $e$ em que base, por que tem ali diversos segmentos, comunidade, universidade, comércio, serviço e comunidade de pescador."

A respeito das duas fases desenvolvidas do Plano de Manejo o Sr. Júlio Vellardi mencionou o seguinte:

- "Tanto a fase 1 quanto a 2 tem um lado positivo, que foi de agregar a comunidade, diversos segmentos, científica, moradores, ONGs, mas ao mesmo tempo uma falha muito gritante é que na fase 2 deveriam melhorar a 
1 e aconteceu o contrário (...) só se utilizou dados secundários, não se fez. nenhum levantamento atual de campo. Nessas fases não tem estudos de fauna, de solo, de declividade e não tem por conseqüência um estudo que amarre declividade, cobertura, hidrologia e tipo de solo, pra definir fragilidade e potencialidade. O que aconteceu que é uma prova concreta dessa inabilidade é a trilha de Itaquitanduva, você tem processos erosivos enormes o que dificulta a própria implantação imediata dessa trilha mesmo com o plano de manejo sendo concluído."

Essas afirmativas, junto ao conteúdo das fases elaboradas do Plano de Manejo do PEXJ, podem revelar problemas de planejamento e execução no órgão executor (IF), o que também foi ressaltado pelo Dr. Denis Abessa em uma de suas falas. Sendo assim a não implementação das diretrizes da fase 1 e não aprovação da fase seguinte certamente tem relação com tais problemas, o que pode ser ainda acentuado pela falta de recursos e complicações operacionais.

Em 2003 houve mudança do gestor da unidade, assumindo o cargo até os dias atuais o Sr. Eduardo Lourenço. Foi durante essa gestão que a sede administrativa do Parque foi transferida para o entorno da unidade, deixando de estar a mais de oito quilômetros de distância do mesmo. Algumas parcerias foram feitas com representantes das comunidades de entorno. Em decorrência dessas parcerias a administração do Parque instalou-se temporariamente na casa da Pastoral da Criança do bairro Japuí, localizada no início da trilha da Pedreira, um dos acessos à praia de Itaquitanduva, por intermediações de uma moradora, Dona Inês. Em seguida, mudou-se, também temporariamente, para a casa da Sociedade de Melhoramentos do Parque Prainha, localizada no bairro Prainha. Atualmente a sede do Parque está instalada na antiga construção pertencente à Marinha, na Praia de Paranapuã, sendo que alguns guardas ainda permanecem na casa cedida pela Sociedade de Melhoramentos. $\mathrm{O}$ fato de a sede administrativa do Parque ter mudado da Ponta da Praia para a região de entorno certamente promoveu melhorias quanto à gestão da área. Práticas de fiscalização podem ser desenvolvidas com maior eficácia e freqüência e os funcionários do Parque, principalmente o gestor, passam a ter maior envolvimento e maior conhecimento sobre assuntos cotidianos incidentes no território do Parque, podendo tomar decisões mais sólidas e condizentes com a realidade local, quanto ao manejo e gestão da unidade.

Outra parceria acontece com o Forte Itaipu, o qual faz fiscalização na área 
marinha do Parque, depois de ter sido instruído pela atual administração da unidade. Essa parceria, de acordo com o coordenador do IF, decorre de uma ação de fiscalização desenvolvida pelo Parque na qual se detectou que a pesca nas imediações do Forte Itaipu era permitida pelos militares do Forte. O então comandante do Forte foi comunicado pela gestão do PEXJ e esclarecido sobre as leis que protegem um Parque Estadual, suspendendo a permissão e o Forte passou a ajudar na fiscalização. Deve-se ressaltar que este esclarecimento foi eficiente quando se tratava de pessoas que apresentam um alto discernimento a respeito de disposições legais e que esta mesma postura certamente não é suficiente para lidar com pessoas que não apresentam tal grau de entendimento.

Atualmente o Parque conta com doze vigilantes terceirizados em postos fix os com plantão de 24 horas, três guardas-Parque não terceirizados, uma secretária e dois estagiários. A evolução de recursos humanos do Parque é visível e, assim com a mudança da sede administrativa, tende a otimizar processos de gestão e manejo da área.

O Conselho Consultivo ainda não existe e de acordo com o coordenador e com o diretor da unidade sua implementação se faz importante e urgente, tanto para o cumprimento das disposições do SNUC, como para inserir a sociedade civil nos assuntos do Parque. A integração da sociedade deverá ser feita por meio de oficinas e audiências públicas, e o principal foco é resgatar a relação com os atores sociais envolvidos na elaboração da fase 2 do Plano de Manejo. Tanto a implementação do Conselho Consultivo como o desenvolvimento dessas oficinas, deverão ocorrer quando for iniciada a re-elaboração da fase 2, que será desenvolvida em parceria com a Unesp, Campus do Litoral Paulista, e cujos trâmites burocráticos já estão em andamento.

De acordo com o gestor do Parque houve perda da credibilidade com a comunidade, o que sob sua concepção decorre da estagnação das fases do Plano de Manejo. Esse distanciamento também pode estar relacionado com a gestão anterior do Parque, cujos esforços para inserção da comunidade eram baixos, situação que persiste ainda hoje, seja por dificuldades financeiras, operacionais ou internas de gestão.

O gestor foi questionado sobre ter encontrado dificuldades de inserção da comunidade nos assuntos e práticas de conservação. A resposta para essa questão foi positiva, sendo que as dificuldades dizem respeito a problemas sociais e 
econômicos, quando se trata da inserção de pessoas que praticam atividades extrativas no Parque. O gestor mencionou que a inserção da comunidade é positiva, uma vez que as pessoas podem assumir papel de agente multiplicador em prol da conservação da unidade. Ainda relatou que a comunidade pode contribuir com a execução de ações integradas, dando como exemplo a coleta de lixo nas trilhas e praia. De acordo com Oliveira (2006) no início de sua gestão o diretor fez uma reunião com moradores do entorno para apresentar o Parque e seus objetivos, no entanto esse tipo ação parece não ter tido continuidade. Este autor também identificou a falta de transparência da gestão para com a comunidade civil, tal situação pode ser um agravante da dificuldade de relacionamento da administração do Parque com outros segmentos.

É importante, para não atribuir a baixa inserção da comunidade apenas à falta de ações da administração do Parque, ressaltar que, de acordo com membros da ONG "SOS Itaquitanduva", com o diretor do Parque e com o supervisor da Regional do Bairro, a minoria da comunidade procura por estas entidades para se informar ou tratar de assuntos relativos ao Parque. Essa postura assumida pelos moradores pode ser conseqüência, pelo menos em parte, do abandono histórico desta comunidade por parte do poder público, como será detalhado a diante.

Ainda hoje, práticas ilegais são desenvolvidas no território do Parque, o que gera conflitos com a comunidade de entorno, ao passo que a fiscalização tornou-se mais eficiente. Hauff (2004) também reportou que ações de fiscalização trazem conflitos para a relação entre comunidades rurais locais e a administração de unidades de conservação do Brasil. Dentre as práticas ilegais desenvolvidas no PEXJ estão principalmente a caça, pesca, retirada de marisco e o acampamento, cabendo ressaltar, como já mencionado, que tais atividades eram desenvolvidas pela comunidade mesmo antes da criação do Parque, e isso pode demonstrar um caráter cultural que não é facilmente abandonado, ainda mais se considerarmos a falta de informação e de ações voltadas para estas pessoas. De acordo com Lucas (1992) a conscientização e convencimento dos moradores sobre a importância da natureza e da biodiversidade, seja de seus valores intrínsecos, humanos ou de sustentação para a própria vida, são fundamentais para resolução de problemas como estes. Ainda sobre esse assunto, Hauff (2004) encontrou que quando as unidades desenvolveram ações de repasse de informações sobre a importância da conservação da natureza e de oferecimento de oportunidades de trabalho à comunidade, o conflito decorrente 
de práticas de fiscalização diminuía. Sendo assim, a falta de comunicação é um fator que atua aprofundando os conflitos existentes.

É importante mencionar que ações de fiscalização que minimizaram a pesca de rede em áreas do Parque e que levaram a um conflito com os pescadores, também deram indícios positivos. De acordo com Sr. Júlio Vellardi o Parque recebeu uma carta de agradecimento de moradores da região estuarina de São Vicente e Cubatão por terem voltado a pescar e, segundo o coordenador, tal condição deve-se à otimização da fiscalização marinha em áreas do PEXJ, permitindo que esse recurso voltasse a ocorrer em áreas adjacentes.

Observando o desenvolvimento das práticas de gestão em Unidades de Conservação, percebe-se que ações de fiscalização e consequentemente proibições de u so nesses territórios ocorrem com freqüência, o que parece ser o caso do PEXJ. De acordo com Dr. Denis Abessa essa postura tem mudado atualmente, sendo que as ações de gestão pautam-se cada vez mais em práticas participativas. Essa mudança na gestão das UC certamente deve-se aos pressupostos do SNUC, que determinada gestão e manejo participativos nesses territórios, bem como a crescente abordagem desse assunto no meio acadêmico. Essa nova postura tem se mostrado mais eficiente em alcançar os objetivos dessas áreas protegidas.

O relacionamento entre a ONG "SOS Itaquitanduva" e a administração do PEXJ mostra-se conflituoso e perdura desde a última gestão desta organização. Outro ponto negativo no que concerne às relações com o Parque diz respeito à Regional do Bairro Japuí. De acordo com o supervisor dessa entidade houve a tentativa frustrada de fazer ações integradas com o Parque, como por exemplo, dar palestras nas escolas. Este seria mais um meio de atuação do Parque que não ocorre, no entanto é importante lembrar, assim como destacado por Oliveira (2006), que o fato de se conseguir parceria com uma instituição ou uma ONG é apenas metade do caminho para a efetividade desta ação, que ainda depende de outros fatores.

\section{3.Perfil dos moradores}

\subsubsection{Perfil e caracterização social}

Do total de entrevistados $53 \%$ eram mulheres e $47 \%$ eram homens, a proporção entre mulheres e homens foi mantida a mais próxima possível para que 
não houvesse diferenças nas respostas adquiridas quanto ao gênero. A grande maioria dos entrevistados reside a mais de 10 anos no bairro (80\%), sendo o tempo médio de moradia 24,4 anos e variando de 2 até 56 anos (Tabela 2).

Tabela 2 - Porcentagem e número de entrevistados quanto ao tempo de moradia

\begin{tabular}{lcc}
\hline \multicolumn{1}{c}{ TEMPO DE MORADIA } & $\mathbf{N}^{\circ}$ & $\mathbf{\%}$ \\
\hline 1-5 anos & 2 & 6,7 \\
6-10 anos & 4 & 13,3 \\
11-20 anos & 5 & 16,7 \\
21-30 anos & 11 & 36,7 \\
31-40 anos & 3 & 10,0 \\
41-50 anos & 4 & 13,3 \\
>50 anos & 1 & 3,3 \\
TOTAL & $\mathbf{3 0}$ & $\mathbf{1 0 0}$ \\
\hline
\end{tabular}

A média da faixa etária foi de 46 anos, variando de 17 a 74 anos. Os intervalos de idade com maiores percentuais foram acima de 51 anos e entre 21 e 30 anos, com $50 \%$ e $17 \%$, respectivamente (Figura 4).

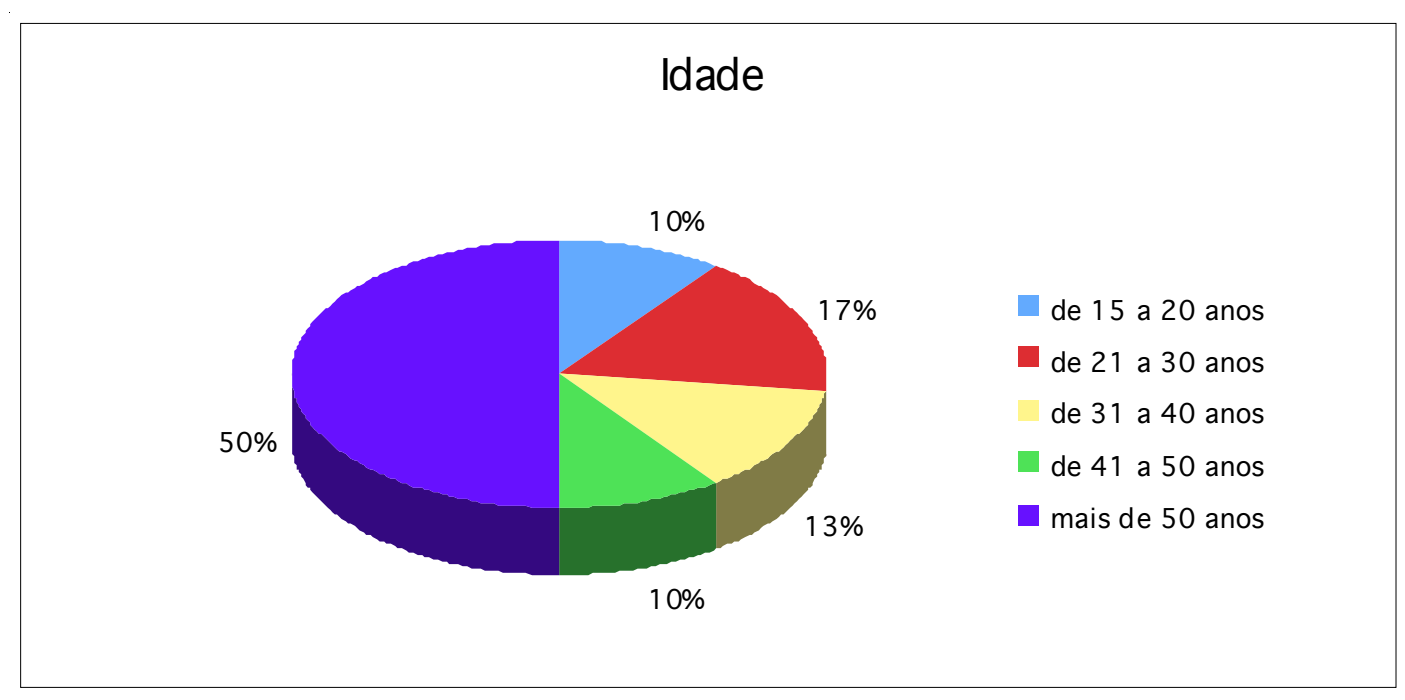

Figura 4 - Gráfico do intervalo de idades dos moradores e suas respectivas porcentagens

A escolaridade dos entrevistados distribui-se desde o Ensino Fundamental Incompleto até o Ensino Superior Completo, sendo que este último grau apresenta igual porcentagem a de analfabetismo (3,3\%), a menor dentre todos os outros. Os moradores que concluiram o Ensino Médio perfazem 26,7\% e os que apresentam 
Ensino Fundamental tanto completo como incompleto perfazem juntos $46,6 \%$ do total (Tabela 3). A diferença do grau de instrução não influenciou na informação ou no relacionamento dos entrevistados com o PEXJ.

Tabela 3 - Número e porcentagem dos moradores quanto à escolaridade

\begin{tabular}{lcc}
\hline \multicolumn{1}{c}{ ESCOLARIDADE } & $\mathbf{N}^{\circ}$ & $\mathbf{\%}$ \\
\hline Analfabeto & 1 & 3,3 \\
Fundamental Incompleto & 7 & 23,3 \\
Fundamental Completo & 7 & 23,3 \\
Médio Incompleto & 4 & 13,3 \\
Médio Completo & 8 & 26,7 \\
Superior Incompleto & 2 & 6,7 \\
Superior Completo & 1 & 3,3 \\
TOTAL & $\mathbf{3 0}$ & $\mathbf{1 0 0}$ \\
\hline
\end{tabular}

Dos entrevistados 26,7\% são aposentados. As ocupações foram divididas em empregatícias e autônomas, sendo que a porcentagem da primeira é de $43,3 \%$ e da segunda de $20 \%$. Uma pessoa não trabalha, uma está desempregada e uma é estudante, juntas perfazem $10 \%$ do total. A Tabela 10 apresenta as ocupações citadas de forma agrupada. 
Tabela 4 - Número e porcentagem de moradores quanto à ocupação

\begin{tabular}{clcc}
\hline \multicolumn{1}{c}{ TIPO } & \multicolumn{1}{c}{ OCUPAÇÃO } & $\mathbf{N}^{\circ}$ & $\mathbf{\%}$ \\
\hline & Agente de Organização Escolar & 4 & 13,3 \\
& Ajudante Geral & 1 & 3,33 \\
& Atendente & 1 & 3,33 \\
& Balconista & 1 & 3,33 \\
\multirow{3}{*}{ Empregatício (43,3\%) $)$} & Estagiário & 1 & 3,33 \\
& Manobrista & 1 & 3,33 \\
& Merendeira & 1 & 3,33 \\
& Militar & 1 & 3,33 \\
& Empregada Doméstica & 1 & 3,33 \\
& Meio Oficial de Mecânica & 1 & 3,33 \\
\hline \multirow{3}{*}{ Autônomo (20\%) $)$} & Comerciante & 2 & 6,7 \\
& Cabeleireira & 2 & 6,7 \\
& Pedreiro & 1 & 3,33 \\
& Manicure & 1 & 3,33 \\
\hline Outros (36,7\%) & Aposentados & 8 & 26,7 \\
& Estudantes & 1 & 3,33 \\
& Desempregados & 1 & 3,33 \\
& Não trabalha & 1 & 3,33 \\
\hline & TOTAL & $\mathbf{3 0}$ & $\mathbf{1 0 0}$ \\
\hline
\end{tabular}

Nenhum dos entrevistados faz parte de ONG ou alguma associação relacionada ao Parque. Dois moradores $(6,7 \%)$ afirmaram ter atuado como voluntários em ações relacionadas ao PEXJ, seja em grupos informais ou na ONG "SOS Itaquitanduva".

Quando questionados sobre o interesse em participar do desenvolvimento de alguma atividade relacionada ao PEXJ, 70\% dos moradores manifestaram interesse, os outros $30 \%$ disseram não se interessar unicamente pela falta de tempo. É interessante ressaltar a fala de um morador que respondeu ter interesse sobre as atividades:

- "A direção agora é ruim, mas eu daria sugestões se visse que a pessoa tem caráter. Estou disponível ao que for possível."

\subsubsection{Relacionamento com o território}

Apenas $6,7 \%$ dos entrevistados nunca visitaram o Parque, do restante, $56,6 \%$, visita ou já visitou com frequiência superior a uma vez por mês. Os 
moradores que deixaram de visitar o Parque têm de 52 a 72 anos e mencionaram como argumentos a dificuldade da trilha, problemas de saúde, medo ou o fato de terem se machucado quando foram. Dentre estes moradores, quatro deles (13,3\% do total) visitaram a área apenas antes da criação do PEXJ (Figura 5). A baixa porcentagem de moradores que nunca visitou o PEXJ está em consonância com o fato da maioria destes (70\%) ter interesse em participar do desenvolvimento de atividades relacionadas a unidade.

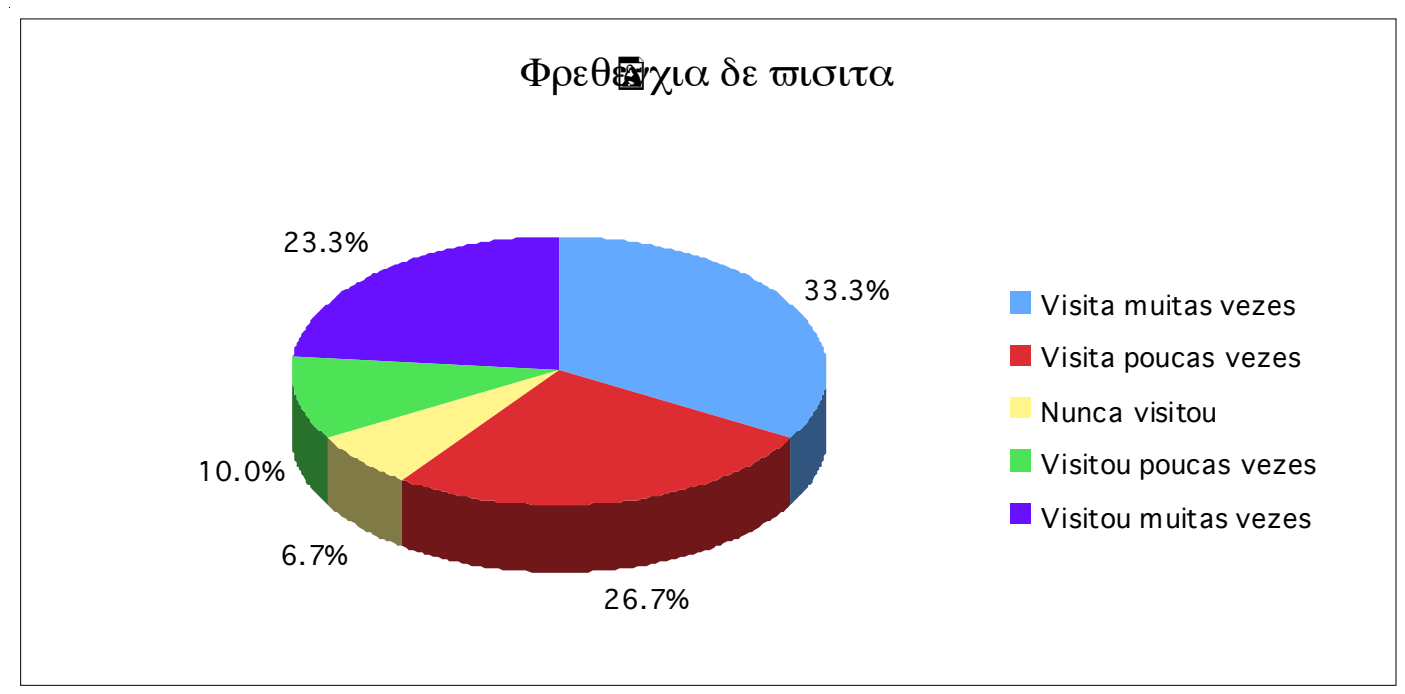

Figura 5 - Gráfico representando a porcentagem de moradores quanto a frequiência de visitas ao PEXJ.

Quando questionados sobre quais atividades praticam no Parque, os moradores que visitavam o PEXJ antes de sua criação citaram práticas relacionadas à aquisição de recursos $(18 \%)$, ao lazer $(8 \%)$ e relacionadas a trabalho $(2 \%)$. Os moradores que ainda visitam ou visitavam depois da criação do Parque relataram atividades relacionadas ao lazer (54\%), a cuidados com a área (8\%), atividades escolares para conhecimento $(6 \%)$ e à aquisição de recursos $(4 \%)$. De acordo com estes, percebe-se que antes da criação do PEXJ as práticas de aquisição de recursos naturais (ou seja, uso direto) eram pelo menos quatro vezes mais freqüentes e depois da criação as atividades de lazer aumentaram cerca de sete vezes. Duas pessoas $(6,7 \%)$ não foram indagadas quanto a essa pergunta por nunca terem visitado o PEXJ. A Figura 6 demonstra as frequiências relativas das citações de atividades praticadas antes e depois da criação do Parque. 


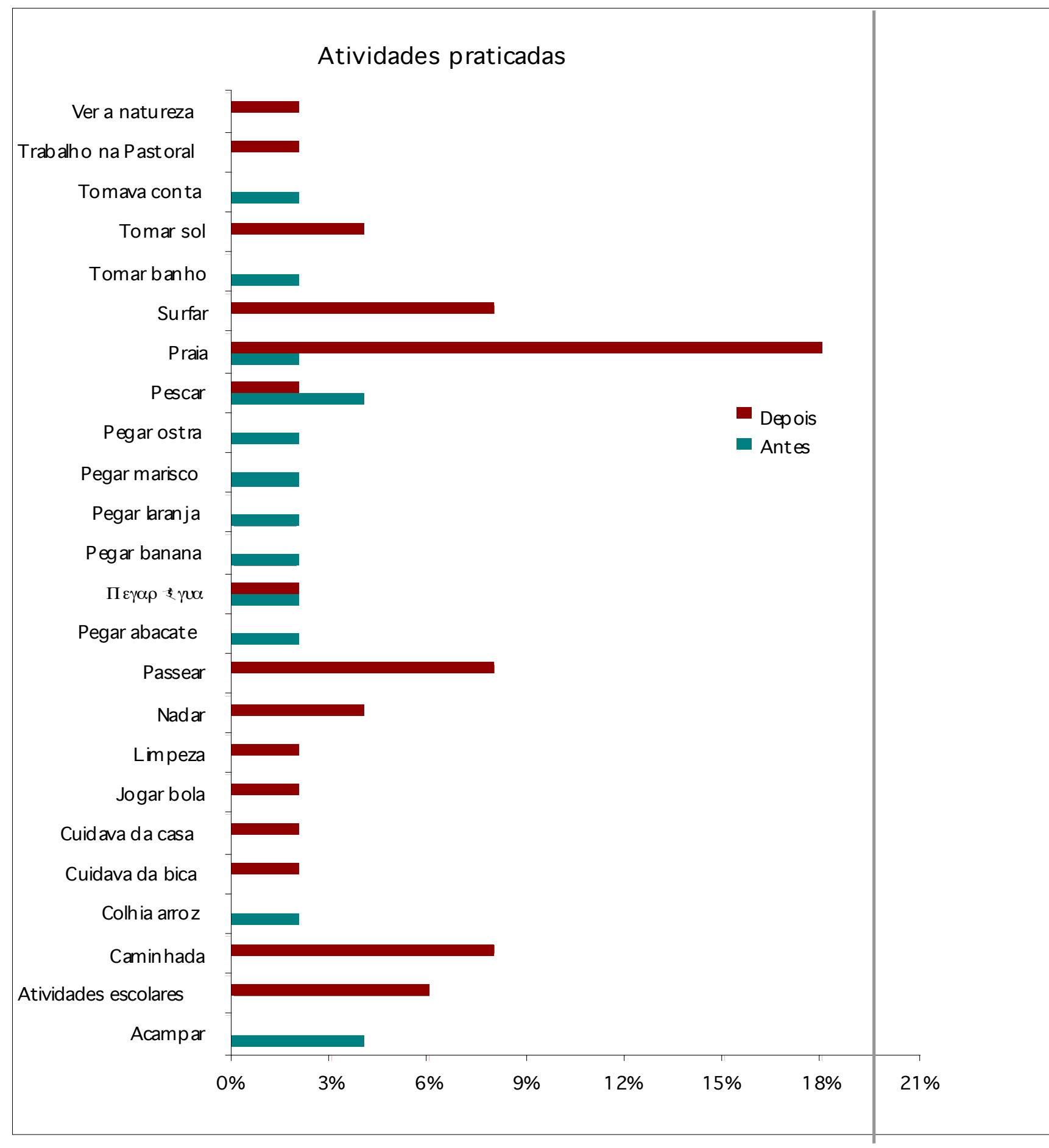

Figura 6 - Gráfico das atividades desenvolvidas no território do PEXJ, antes e depois de sua criação e respectivas freqüências relativas.

\subsubsection{Informação Ambiental}

Todos os entrevistados foram questionados quanto ao conhecimento da fauna e flora do Parque, uma vez que morando muito próximo ao Parque têm oportunidade de conhecer ou saber da existência de sua biota. Apenas 10\% dos 
entrevistados citaram exemplares da flora, sendo estes, banana, jaca e orquídea, todos com 33,3\% de citações. Ainda foram citadas especificadamente banana pão e banana vinho. A baix a informação ambiental a cerca da flora fica clara uma vez que apenas três moradores (10\%) mencionaram representantes desse grupo. O fato de banana ser citada demonstra o baixo conhecimento a cerca dos preceitos ecológicos dessa Unidade de Conservação.

Quanto a fauna, a maioria das citações foi de mamíferos $(44,5 \%)$, seguidos por répteis $(25,7 \%)$, invertebrados $(13,9 \%)$, aves $(12,9 \%)$ e peixes $(3,0 \%)$. Os mamíferos mais citados foram tatu (11 citações) e raposa (10 citações) (Figura 7).

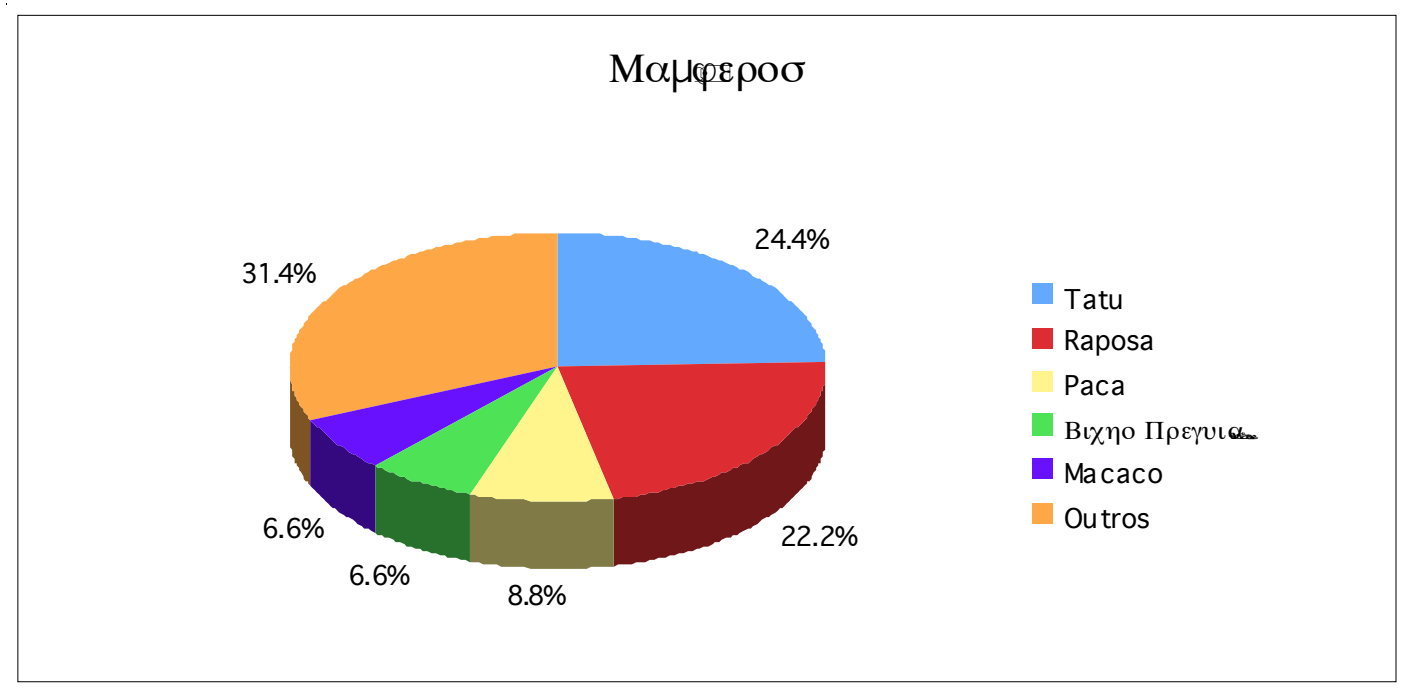

Figura 7 - Gráfico dos representantes de mamíferos citados e respectivas porcentagens. Dentre a série outros estão, com $2 \%$ das citações, veado, preá, sagüi e esquilo; com $1 \%$ vaca, tamanduá, rato do banhado, quati, lebre, cutia

Os répteis mais citados foram cobra e lagarto (11 e 10 citações, respectivamente). Para este grupo foram mencionados também tartaruga e teiú, e especificados as cobras caninana, cascavel, cega, coral, jaracuçu e jararaca. O fato de tatu, raposa, cobra e lagarto terem sido os animais mais mencionados pode ser por que estes são alvo de caça e/ou perigosos.

Dos invertebrados $71,4 \%$ eram marinhos (marisco, siri, ouriço do mar, ostra, mexilhão e caranguejo) e 28,6\% terrestres (borboleta, caramujo e aranha). Os mais citados foram marisco e borboleta (5 e duas citações, respectivamente), os outros foram citados apenas uma vez.

Para as aves foram citados genericamente pássaros, garça (nove e duas 
citações, respectivamente), maritaca e galinha (ambos com uma citação). Foram especificados alguns exemplares de pássaros, dentre estes, bico de lata, coleirinha, jacu, sabiá de peito amarelo, tié roxo e tié vermelho. É importante mencionar que os pássaros especificados são alvo de caça, associados ao ambiente urbano e/ou freqüentemente criados. Os peixes foram citados 9 vezes sendo especificados miraguaia, pampo e salgo.

Os moradores que disseram não conhecer representantes da fauna e flora do Parque perfazem $16,7 \%$ e não estão entre os que nunca visitaram a área.

Para esta questão, exceto para as citações de tatu, raposa, cobra, lagarto e os genéricos pássaros e peixes, os outros animais foram citados no máximo por cinco moradores $(16,7 \%$ do total de entrevistados), sendo que $48,5 \%$ do total de animais foram citados apenas uma vez. Os baix os valores de citações podem indicar um baixo conhecimento dos moradores a cerca da fauna existente no Parque e consequentemente baixa informação ambiental. É importante destacar que dentre os representantes marinhos citados, $73,7 \%$ são organismos utilizados como recurso alimentar ou econômico, isso considerando apenas marisco e peixe, que foram citados por moradores como sendo utilizados pela comunidade. Ainda, foram citados organismos exóticos, sendo estes caramujo (Achatina fulica), galinha e vaca. Para estes dois últimos a menção foi feita em tom de ironia pela entrevistada, demonstrando seu conhecimento de que esses animais não fazem parte dessa paisagem, no entanto para o caramujo isso não aconteceu.

As respostas quanto as diferenças entre o PEXJ e outras áreas verdes foram agrupadas em categorias ou condições da área, estas são apresentadas em ordem decrescente quanto a porcentagem total de citações:

- Serviços do Meio Ambiente, com 26,4\% das citações, sendo mencionadas dez diferenças, sendo que a mais freqüente, no entanto mencionada apenas por cinco moradores (16,7\% do total de entrevistados) foi o ar puro (Tabela $5)$. 
Tabela 5 - Número de citações e porcentagem das diferenças quanto aos serviços do meio ambiente

\begin{tabular}{lll}
\hline \multicolumn{1}{c}{ SERVIÇOS DO MEIO AMBIENTE } & $\mathbf{N}^{\circ}$ & $\mathbf{\% t}$ \\
\hline Ar puro & 5 & 35,7 \\
Clima & 1 & 7,14 \\
Área saudável & 1 & 7,14 \\
Pureza & 1 & 7,14 \\
Cheiro & 1 & 7,14 \\
Local de repouso familiar & 1 & 7,14 \\
Transmite paz & 1 & 7,14 \\
Sossego & 1 & 7,14 \\
Área boa & 1 & 7,14 \\
Ar fresco & 1 & 7,14 \\
TOTAL & $\mathbf{1 4}$ & $\mathbf{1 0 0}$ \\
\hline
\end{tabular}

- Conservação/Preservação, com 20,8\%, cujas diferenças mais freqüentes foram preservação (4 citações), praia mais limpa e conservação, ambas citadas duas vezes (Figura 8).

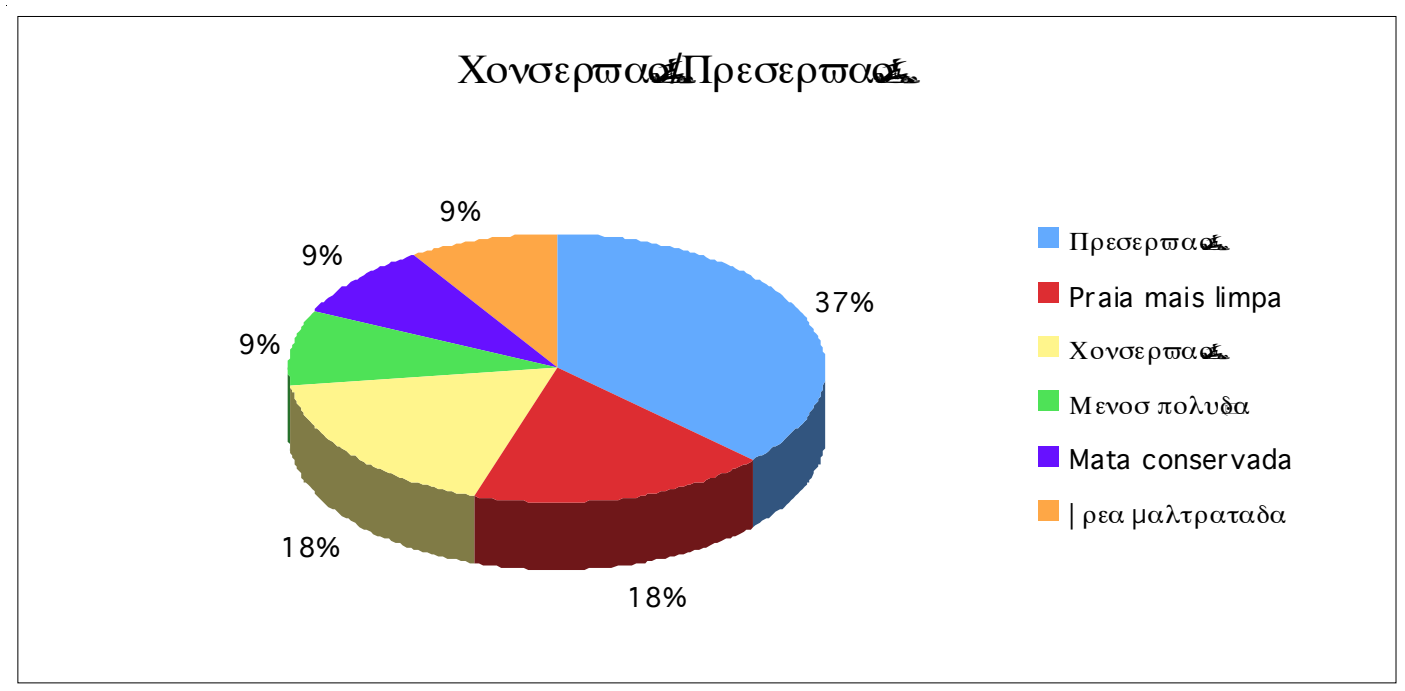

Figura 8 - Porcentagem das diferenças citadas quanto à conservação/preservação

- Aspectos cênicos, com 13,2\%, sendo que a mais citada foi beleza, com três menções (Figura 9). 


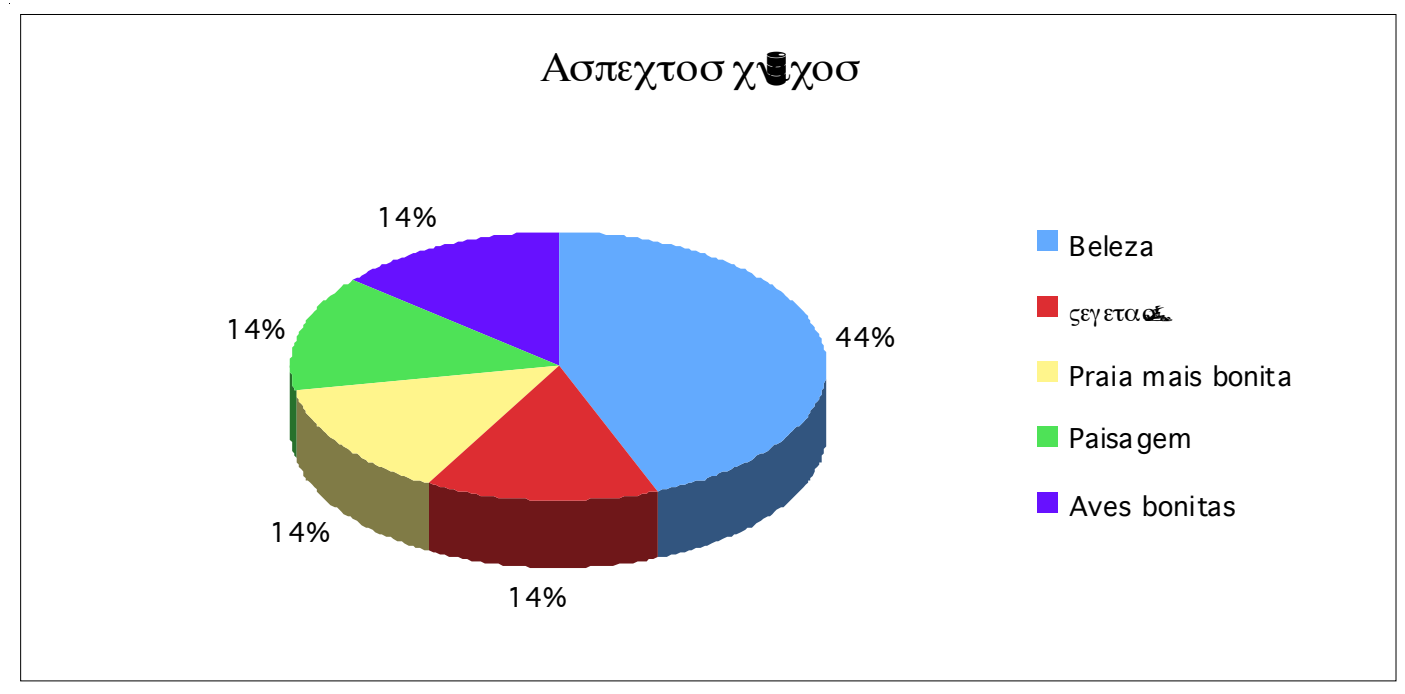

Figura 9 - Porcentagem das diferenças citadas quanto aos aspectos cênicos

- Cuidados com a Área do Parque, com 13,2\% das citações. Nenhuma diferença mencionada para esta categoria foi citada mais de uma vez, sendo que apenas seis pessoas (20\% do total) relacionaram tais itens (Tabela 6).

Tabela 6 - Número de citações e porcentagem das diferenças quanto aos cuidados com a área

\begin{tabular}{lcc}
\hline \multicolumn{1}{c}{ CUIDADOS COM A ÁREA } & $\mathbf{N}^{\circ}$ & $\mathbf{\% t}$ \\
\hline Comunidade não deixa pessoas de fora entrarem & 1 & 14,3 \\
Guardas do forte cuidam & 1 & 14,3 \\
Pessoas trazem o lixo de volta & 1 & 14,3 \\
Comunidade cuida & 1 & 14,3 \\
Florestal cuida & 1 & 14,3 \\
Estado cuida & 1 & 14,3 \\
IBAMA cuida & 1 & 14,3 \\
TOTAL & $\mathbf{7}$ & $\mathbf{1 0 0}$ \\
\hline
\end{tabular}

- Potencial de Visitação (5,7\%), cujas diferenças foram citadas uma única vez por apenas três pessoas (10\% do total). Estas diferenças foram a vinda de pessoas de longe para visitar o Parque, as muitas cois as que existem para ver na mata e o fato de a área ser boa para visitação.

- Presença de Bicas (5,7\%). As diferenças relacionadas a essa condição também foram citadas por três moradores, sendo que dois deles mencionaram a simples ocorrência de bicas e o terceiro citou a presença da 
bica na praia de Itaquitanduva.

- Área Protegida (3,8\%). Apenas dois entrevistados (6,7\% do total) mencionaram diferenças relativas a esta condição, sendo estas o fato do território ser tombado e a existência de placa informativa sobre área protegida.

- Ocupação $(3,8 \%)$, sendo as diferenças quanto a essa condição que ao Parque não tem moradia e não tem favela. Também citadas por apenas dois moradores.

- Afetividade com 3,8\%, para esta categoria duas pessoas disseram que gostam muito do Parque.

- Acesso $(3,8 \%)$, cujas diferenças, mencionadas por dois moradores para esta condição, foram o isolamen to do Parque e a facilidade de acesso a este.

Apenas um entrevistado não soube responder a pergunta (1,9\% do total de respostas obtidas) e outros dois $(3,8 \%)$ disseram não ver diferença entre o Parque e outras áreas naturais. Para esta pergunta observa-se o mesmo padrão da questão anterior sobre o conhecimento da fauna e flora. Neste caso mesmo as diferenças mais citadas não foram mencionadas por mais de cinco pessoas, o que demonstra baixa informação ambiental dos moradores, por exemplo, pelo fato de nenhuma diferença relacionada aos serviços do meio ambiente ter sido citada por mais de cinco moradores.

Dentre os entrevistados, $60 \%$ dos moradores detectaram problemas no território do Parque, os quais também foram agrupados quanto a sua relação com a Conservação, Segurança, Gestão, Ocupação, Limpeza, Acesso, Atuação da ONG "SOS Itaquitanduva" e Disponibilidade de Informação (Figura 10). Dos $40 \%$ de moradores que disseram não detectar nenhum problema no Parque, 16,7\% nunca visitaram a área e 33,3\% deixaram de visitá-la. Os problemas mais citados não apresentam mais de três menções, o que continua seguindo o padrão de baixa informação ambiental por parte dos moradores, bem como baixo conhecimento sobre processos de gestão, isso levando em consideração as tipos de diferenças mencionadas. 


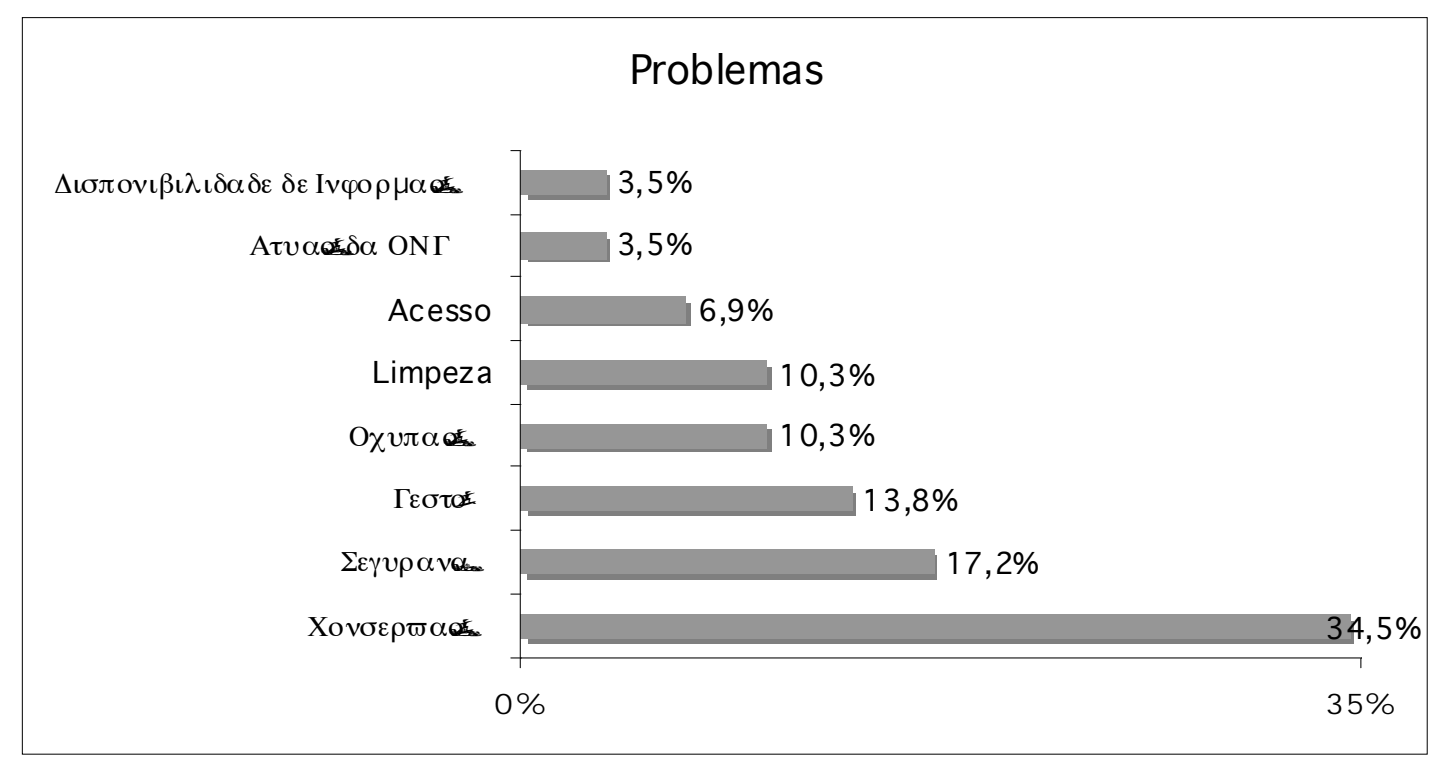

Figura 10 - Porcentagem das classes de problemas citados

Para a Conservação foram citados cinco problemas, sendo os mais expressivos, com 3 citações, as práticas de caça e a retirada da mata. Para o primeiro, especificou-se a captura de pássaros e de raposa, e para a retirada da mata especificou-se que esta atividade foi desenvolvida pela prefeitura de São Vicente e por um candidato a vereador deste mesmo município. Dois entrevistados citaram como problema a colocada de fogo na mata, ambos afirmaram que essa prática não ocorre atualmente, sendo que um deles, quando questionado sobre como essa situação foi resolvida, disse que a polícia florestal tomou providências. A retirada de terra das encostas foi classificada como um problema de conservação, e relacionado a esta prática, o entrevistado disse acontecer o pagamento de propina à membros da polícia (não se sabe qual polícia) para "permissão" de tal atitude. Caso o pagamento de propina tenha realmente ocorrido fica demonstrada a fragilidade do cumprimento dos preceitos ecológicos do Parque, não só em relação às praticas da comunidade de entorno, mas também em relação a diferentes esferas do poder público.

Para corrigir os problemas relacionados à conservação da área, 44,5\% das medidas sugeridas foram de fiscalização, seguida por medidas informativas $(33,3 \%)$, medidas relativas à gestão e a prática de denúncia (ambas com 11,1\%). A Figura 11 mostra os problemas citados quanto à conservação da área e as sugestões para resolvê-los. 


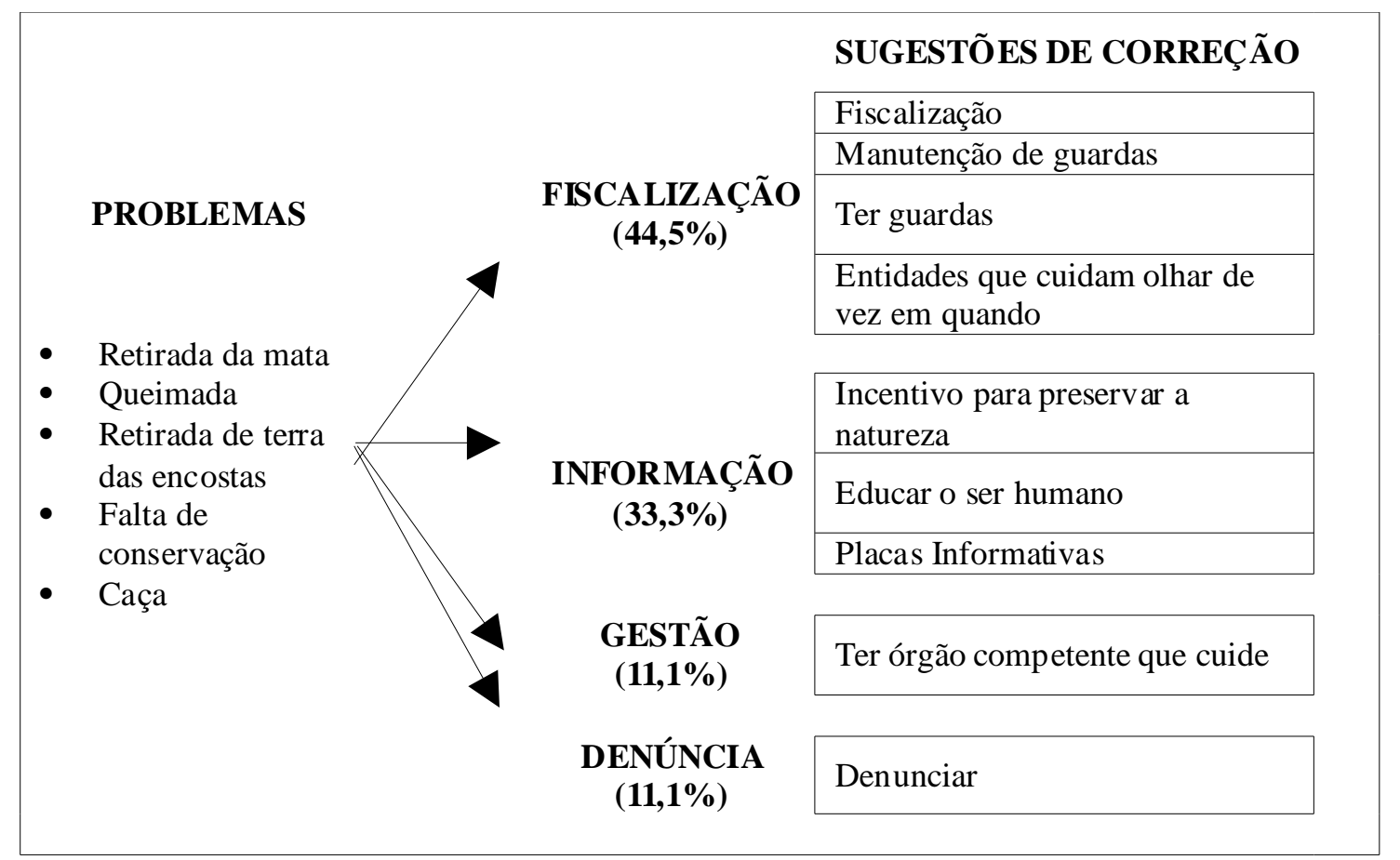

Figura 11 - Problemas quanto a conservação e respectivas sugestões de correção mencionadas pelos moradores

Os problemas relativos à Segurança foram a presença de usuários de drogas no Parque (2 citações), pessoas picadas por cobra, ocorrência de ossada humana e a morte de pessoas no Parque, ambos uma citação. Também foram sugeridas medidas de fiscalização $(42,8 \%)$ para correção, de infra-estrutura $(28,6 \%)$, de gestão e serviços públicos, ambas com 14,3\% (Figura 12). 


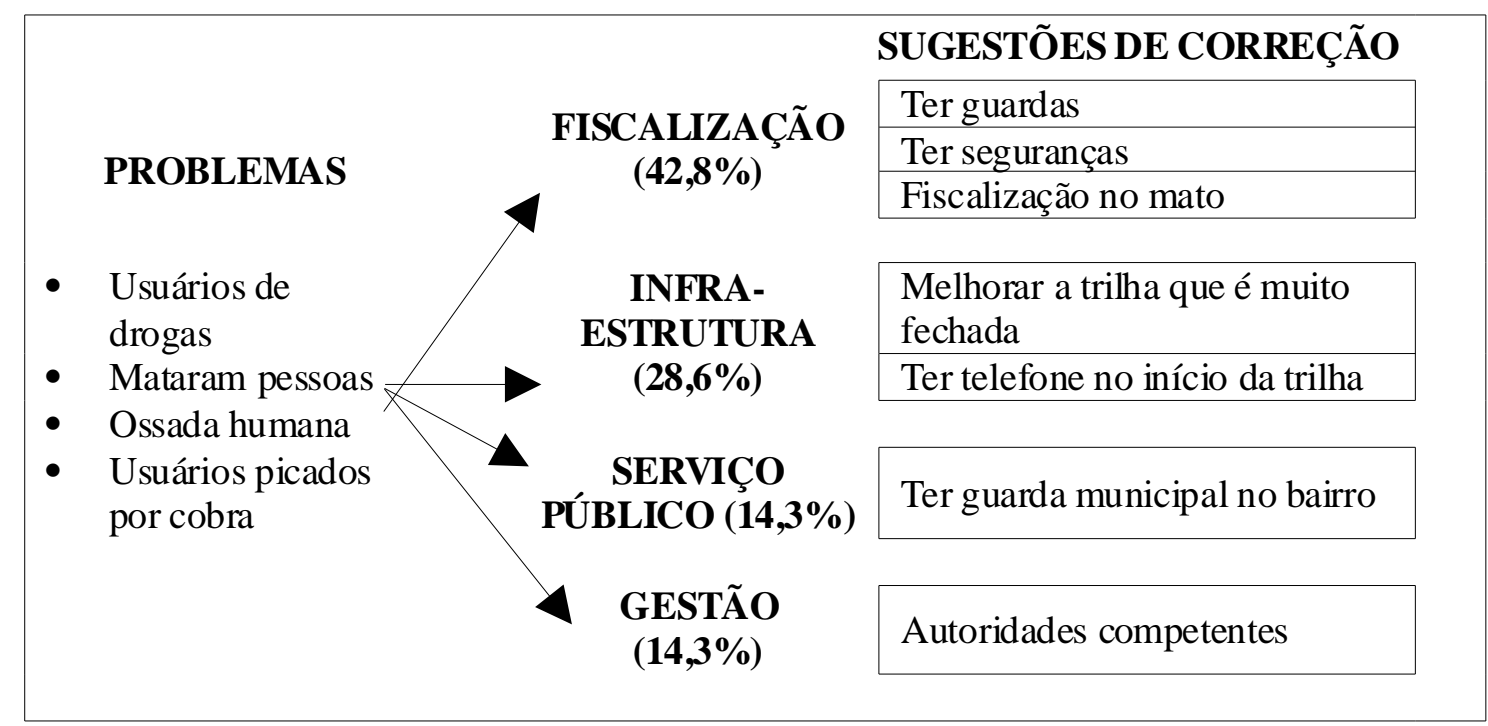

Figura 12 - Problemas quanto à segurança e respectivas sugestões de correção mencionadas pelos moradores

Os problemas de Gestão, foram falta de administração, fiscalização que ocorre só em períodos de temporada, falta de cuidados das instituições responsáveis e o território do Parque totalmente abandonado. Para correção mais da metade das menções disseram respeito à fiscalização (60\%), sugestões quanto à gestão e informação foram igualmente citadas, com 20\% (Figura 13).

\begin{tabular}{|c|c|c|}
\hline PROBLEMAS & & SUGESTÕES DE CORREÇÃO \\
\hline \multirow{5}{*}{$\begin{array}{ll}\text { - } & \text { Falta administração } \\
\text { - } & \text { Fiscalização só na } \\
\text { temporada } \\
\text { - } \\
\text { Falta de cuidados } \\
\text { das instituições } \\
\text { responsáveis } \\
\text { Totalmente } \\
\text { abandonado }\end{array}$} & \multirow{3}{*}{$\begin{array}{l}\text { FISCALIZAÇÃO } \\
(60 \%)\end{array}$} & Monitores que cuidem \\
\hline & & Órgão competente que cuide \\
\hline & & Ter mais fiscalização \\
\hline & $\begin{array}{c}\text { GESTÃO } \\
(20 \%)\end{array}$ & $\begin{array}{l}\text { Pessoas que gostem cuidando, } \\
\text { não só as que tenham interesses }\end{array}$ \\
\hline & $\begin{array}{l}\text { INFORMAÇÃO } \\
(20 \%)\end{array}$ & Mais divulgação \\
\hline
\end{tabular}

Figura 13 - Problemas quanto à gestão e respectivas sugestões de correção mencionadas pelos moradores

Aos problemas referentes à Ocupação, construção de casas na área do Parque e a tentativa de construir um condomínio, sugeriram-se práticas de fiscalização (60\%) e de gestão (40\%) (Figura 14). 


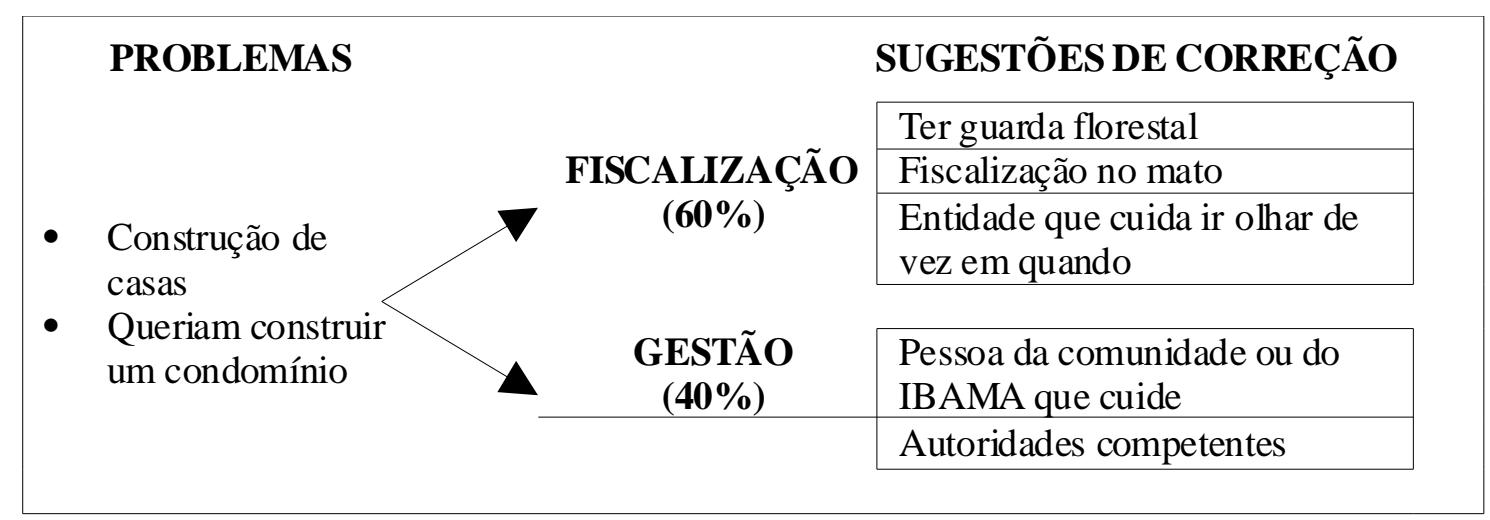

Figura 14 - Problemas quanto à ocupação e respectivas sugestões de correção mencionadas pelos moradores

Em relação à Limpeza da Área do Parque, foram citados três itens, sujeira na trilha, falta de limpeza e descarte de lixo. Medidas de fiscalização, gestão, implantação de infra-estruturas e informação foram sugeridas como métodos de correção (Figura 15). A sugestão proibir de jogar lixo foi classificada como medida de fiscalização, uma vez que esta proibição já ocorre no território de um Parque estadual e reflete o desconhecimento a proibição de tal prática.

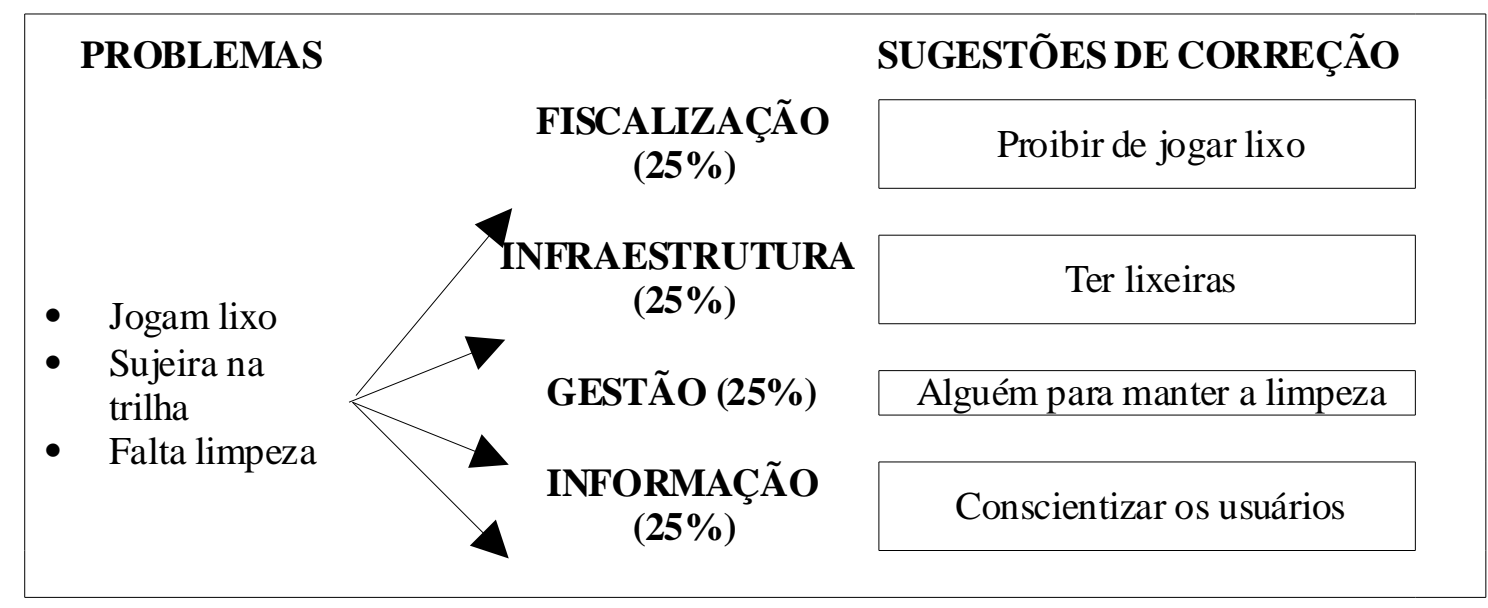

Figura 15 - Problemas quanto à limpeza e respectivas sugestões de correção mencionadas pelos moradores

Os problemas relacionados ao Acesso foram que a trilha é muito fechada e que a seu elevado grau dificuldade, para tais mencionou-se uma única correção, abrir um caminho para o carro passar. Essa medida "corretiva" reflete, mais uma vez, o desconhecimento sobre uma Unidade de Conservação da categoria Parque.

A qualidade da água da bica foi classificada como um problema de 
Disponibilidade de Informação, isso por que a dúvida quanto à qualidade da água decorre de um estudo desenvolvido por membros da Unesp, Campus do Litoral Paulista, no qual os objetivos e a dimensão de tal estudo não teriam esclarecido às pessoas do bairro, gerando o boato de que a água era imprópria para consumo. A medida de correção sugerida para este problema foi de verificar a potabilidade da mesma.

Um entrevistado mencionou que a ONG não cuida mais da área e relacionou tal descuido com a falta de limpeza na praia. Para tal problema não foi citado nem um meio correção.

A maioria das sugestões de correção para os problemas está relacionada com práticas de fiscalização $(43,75 \%)$. Esse percentual relativamente alto pode ser um reflexo da postura de gestão assumida pela administração do Parque, que como já mencionado, parece estar mais direcionada à fiscalização, assim a comunidade passa a enxergar tal prática como única ação de gestão efetiva e passível de ser desenvolvida. Esta postura pode ser uma explicação para a participação da comunidade nos processos de gestão e manejo não aparecer como uma solução dos problemas.

Quando questionados se o Parque traz algum benefício à comunidade, a resposta positiva foi unânime dentre os moradores, tendo uma moradora que citou que se perder o Parque acabou o Japuí. As citações foram divididas em relação aos Serviços do Meio Ambiente, a Recreação, à Obtenção de Recursos, à Beleza, aos benefícios Econômicos, à Segurança e ao Aprendizado. Apenas um morador disse que o Parque beneficia aos animais (Figura 16). 


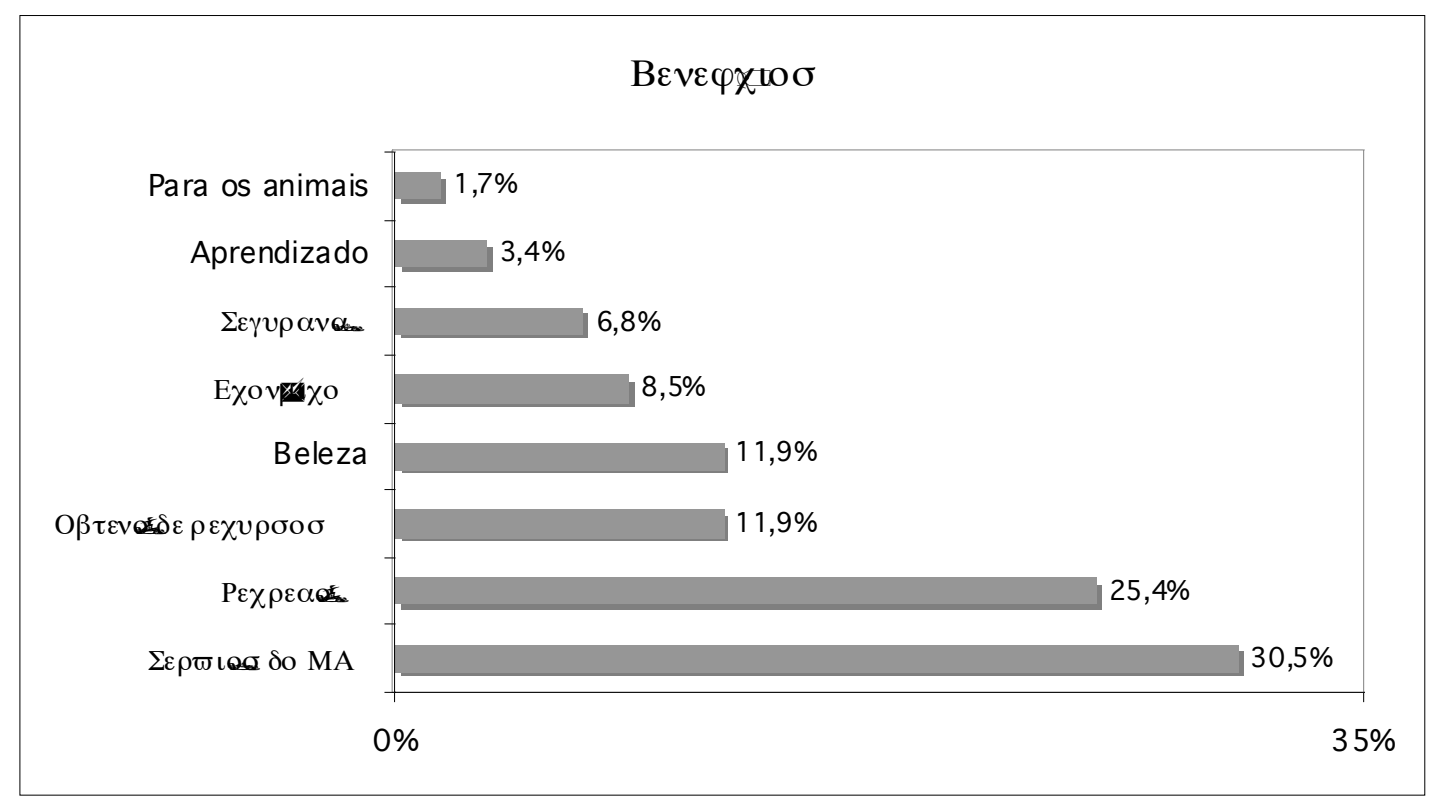

Figura 16 - Porcentagem das classes de benefícios citados

Em relação aos benefícios classificados como Serviços do Meio Ambiente $(30,5 \%)$ o ar puro e a de saúde foram os mais citados, ainda assim apenas quatro pessoas mencionaram estas qualidades (Tabela 7).

Tabela 7 - Número de citações e porcentagem dos benefícios quanto aos serviços do meio ambiente

\begin{tabular}{lcc}
\hline \multicolumn{1}{c}{ SERVIÇOS DO MEIO AMBIENTE } & $\mathbf{N}^{\circ}$ & $\mathbf{\%}$ \\
\hline Ar puro & 4 & 22,2 \\
Saúde & 4 & 22,2 \\
Cheiro da mata & 2 & 11,1 \\
Frescor da natureza & 2 & 11,1 \\
Mata limpa o ar & 1 & 5,56 \\
Não chega maresia & 1 & 5,56 \\
Tem umidade & 1 & 5,56 \\
Tranqüilidade & 1 & 5,56 \\
Traz calma & 1 & 5,56 \\
Ar mais limpo & 1 & 5,56 \\
TOTAL & $\mathbf{1 8}$ & $\mathbf{1 0 0}$ \\
\hline
\end{tabular}

Os benefícios agrupados em Recreação $(25,4 \%)$ estão representados na Tabela 8. O fato de a área ser um lugar para a prática de esportes foi citado por dois moradores, sendo que um deles especificou que isso é importante para as crianças 
que deixam de ficar nas ruas e passam a ir surfar na praia de Itaquitanduva. Um dos entrevistados que mencionou que é uma área para diversão, destacou como ponto positivo a proximidade do Parque com o bairro.

Tabela 8 - Número de citações e porcentagem dos benefícios quanto à recreação

\begin{tabular}{lcc}
\hline \multicolumn{1}{c}{ RECREAÇÃO } & $\mathbf{N}^{\circ}$ & $\mathbf{\%}$ \\
\hline Lazer & 8 & 53,3 \\
Área de esporte & 2 & 13,3 \\
Diversão & 2 & 13,3 \\
Área de passeio & 1 & 6,7 \\
Jovens vão tomar banho & 1 & 6,7 \\
Praia & 1 & 6,7 \\
TOTAL & $\mathbf{1 5}$ & $\mathbf{1 0 0}$ \\
\hline
\end{tabular}

Foram citados apenas três benefícios relativos à Obtenção de Recursos, sendo estes a pesca, a obtenção de água da bica, ambos com 3 citações e perfazendo $5,1 \%$ de todos os benefícios citados, e a retirada de marisco (uma citação e 1,7\% do total). Sendo que a pesca e a retirada de marisco são irregulares.

Apenas cinco itens mencionados dizem respeito à Beleza da área do Parque (Tabela 9).

Tabela 9 - Número de citações e porcentagem dos benefícios quanto à beleza

\begin{tabular}{lccc}
\hline & BELEZA & $\mathbf{N}^{\circ}$ & \% \\
\hline Beleza & 2 & 28,55 \\
Natureza & 2 & 28,55 \\
Área verde & 1 & 14,3 \\
Não tem prédio & 1 & 14,3 \\
Paisagem & 1 & 14,3 \\
TOTAL & 7 & $\mathbf{1 0 0}$ \\
\hline
\end{tabular}

Foram citados apenas dois benefícios Econômicos, sendo estes que o Parque traz turistas para o bairro que consomem no comércio local $(6,8 \%$ do total de benefícios), mencionado por quatro moradores e o cultivo de bananas $(1,7 \%$ e atividade irregular), mencionado por um morador. Dentre os moradores que citaram como benefício econômico a vinda de consumidores, três trabalham no comércio.

Os benefícios relativos à Segurança foram que o Parque evita 
desmoronamentos e a invasão de casas, ambos com 1,7\% do total de citações, além de trazer segurança $(3,4 \%$, citado por duas pessoas). Apenas uma pessoa reconhece que a unidade traz benefícios quan to ao potencial educacional, este morador citou que a área promove noções de ecossistemas e do meio ambiente, ambos os benefícios perfazem $1,7 \%$ do total.

O fato de $100 \%$ dos moradores acharem que o Parque traz benefícios para a comunidade pode demonstrar uma alta afetividade pela área, assim como o fato de ter havido uma "cultura" de não ocupar este território, mesmo antes da criação do PEXJ. Considerando que as questões anteriores mostram baixo conhecimento ambiental dos moradores, a unanimidade em responder que o Parque traz benefícios pode ter sido enviesada pelo simples desenvolvimento da pesquisa a respeito do Parque. Deste modo não se pode afirmar que os moradores conhecem realmente os benefícios que o PEXJ traz ou pode trazer. O fato de nenhum benefício relativo aos Serviços do Meio Ambiente ter sido citado mais de quatro vezes reforça o baixo conhecimento sobre os benefícios e a baixa informação ambiental dos moradores. Ainda, nenhum benefício relativo à geração de renda à comunidade foi citado, o que realça a falta de conhecimento a cerca das potencialidades de uma UC.

A maioria dos entrevistados $(83,3 \%)$ disse não achar que o Parque traz prejuízos para a comunidade. Cinco moradores $(16,7 \%)$ citaram prejuízos quanto à segurança, perfazendo $60 \%$ do total, dentre estes a presença de usuários de drogas, marginais que se escondem na mata e assaltos na trilha. Relacionado a este último prejuízo, mencionou-se perdas sobre comércio local, ao passo que os turistas deixam de visitar a área e consumir. Os outros $40 \%$ são prejuízos relacionados à limpeza do território do Parque, sendo estes, que pessoas de fora deixam lixo e que a sujeira é desagradável. Todos os prejuízos citados contribuíram com a mesma porcentagem do total, $20 \%$ (Tabela 10). 
Tabela 10 - Número de citações e porcentagem dos prejuízos quanto à segurança e limpeza

\begin{tabular}{|c|c|c|c|c|c|}
\hline \multicolumn{6}{|c|}{ PREJUÍZOS } \\
\hline SEGURANÇA & $\mathbf{N}^{\circ}$ & $\%$ & LIMPEZA & $\mathbf{N}^{\circ}$ & $\%$ \\
\hline Presença de usuários de drogas & 1 & 33,3 & $\begin{array}{l}\text { Pessoas de fora deixam } \\
\text { lixo }\end{array}$ & 1 & 50 \\
\hline Marginais se escondem na mata & 1 & 33,3 & A sujeira é desagradável & 1 & 50 \\
\hline Assaltos na trilha & 1 & 33,3 & & & \\
\hline TOTAL & 3 & 100 & TOTAL & 2 & 10 \\
\hline
\end{tabular}

Reigota (1991) dividiu as concepções de meio ambiente em três tipos:

- Naturalista - na qual o meio ambiente é sinônimo de natureza intocada, evidenciando-se somente seus aspectos naturais;

- Globalizante - evidenciam-se as relações recíprocas entre a natureza e a sociedade;

- Antropocêntrica - evidencia-se a utilidade dos recursos naturais para a sobrevivência do ser humano.

De acordo com os resultados adquiridos para as questões de informação ambiental, seguindo as definições desse autor, pode-se considerar que a comunidade percebe o Parque tanto de maneira globalizante quanto antropocêntrica.

\subsubsection{Conhecimento sobre a UC e disponibilidade de informações}

Sobre o conhecimento da área do Parque ser protegida por legislações específicas, $86,7 \%$ dos moradores disse que sabia, sendo citados alguns argumentos para tal afirmação, dentre estes, a Defesa Civil e o IBAMA irem à área com freqüência, ter conhecidos que trabalham como policiais florestais, ter visto pessoas demarcando a área do Parque, escutar pessoas falarem ou simplesmente citar o IBAMA e a polícia florestal. Os argumentos citados demonstram que os moradores desconhecem que o Instituto Florestal é a real instituição gestora. O restante (quatro moradores) não sabia que a área era protegida por legislações.

Mesmo a maioria sabendo que o Parque é uma área protegida legalmente, quando questionados se sabiam se o Parque tem uma sede administrativa e onde 
esta se instala, apenas $20 \%$ do total de entrevistados respondeu corretamente à pergunta. Esse baixo percentual pode refletir pouca disponibilidade de informações para a comunidade. Os moradores que disseram saber da existência da sede perfazem $46,7 \%$ e os que não sabiam $50 \%$. Um entrevistado $(3,3 \%)$ respondeu que "deve existir sede administrativa, se não como iriam tocar o Parque."

Dentre os quatorze moradores que responderam saber da existência da sede (46,7\% do total de entrevistados), seis responderam corretamente e cinco erraram o local onde a administração se instala, citando ser na Regional do Bairro Japuí, na ONG "SOS Itaquitanduva", ser dos surfistas, na escola de surf e na Pastoral da Criança. Cabe ressaltar que este último local citado já abrigou a administração do Parque, no entanto a mudança para a atual alocação ocorreu em 2007. A porcentagem de moradores que afirmou saber da existência da sede administrativa, mas que não sabia onde se instala foi de 21,4\% (três moradores) (Figura 17). Os resultados obtidos para essas duas questões ilustram a ausência de relacionamento entre a comunidade e a administração do PEXJ.

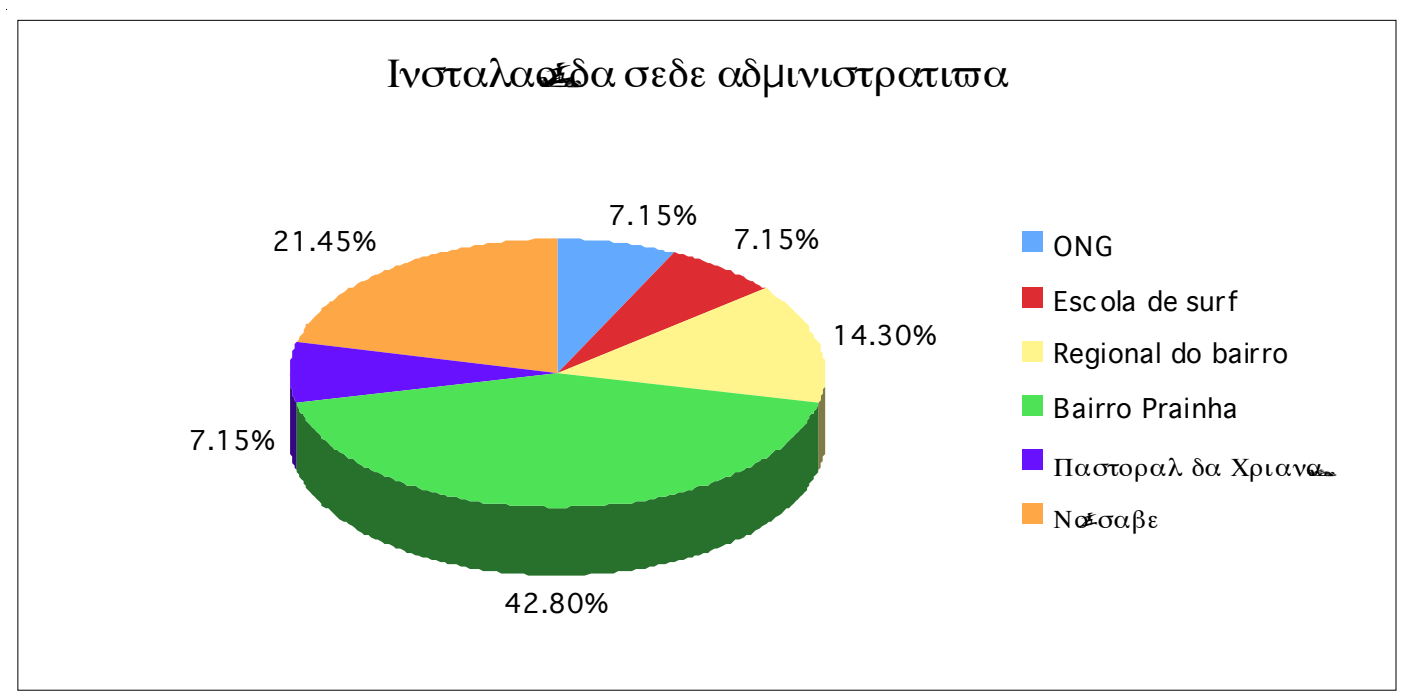

Figura 17 - Porcentagem dos lugares citados onde se instalaria a sede administrativa do PEXJ de acordo com os moradores que afirmaram saber da existência desta

Os entrevistados que não sabiam se existe sede administrativa perfazem $50 \%$ do total e destes, $66,7 \%$ sugeriram lugares onde pensaram ser, sendo estes na ONG (3 citações), na Pastoral da Criança e na Regional do Bairro (ambas com duas citações), na Prefeitura de São Vicente, na Escola de Surf do bairro e no Instituto Florestal (todas com uma citação). Essas menções demonstram mais uma vez a falta 
de informações do PEXJ à comunidade e o baixo conhecimento desta sobre a instituição gestora da unidade (Figura 18).

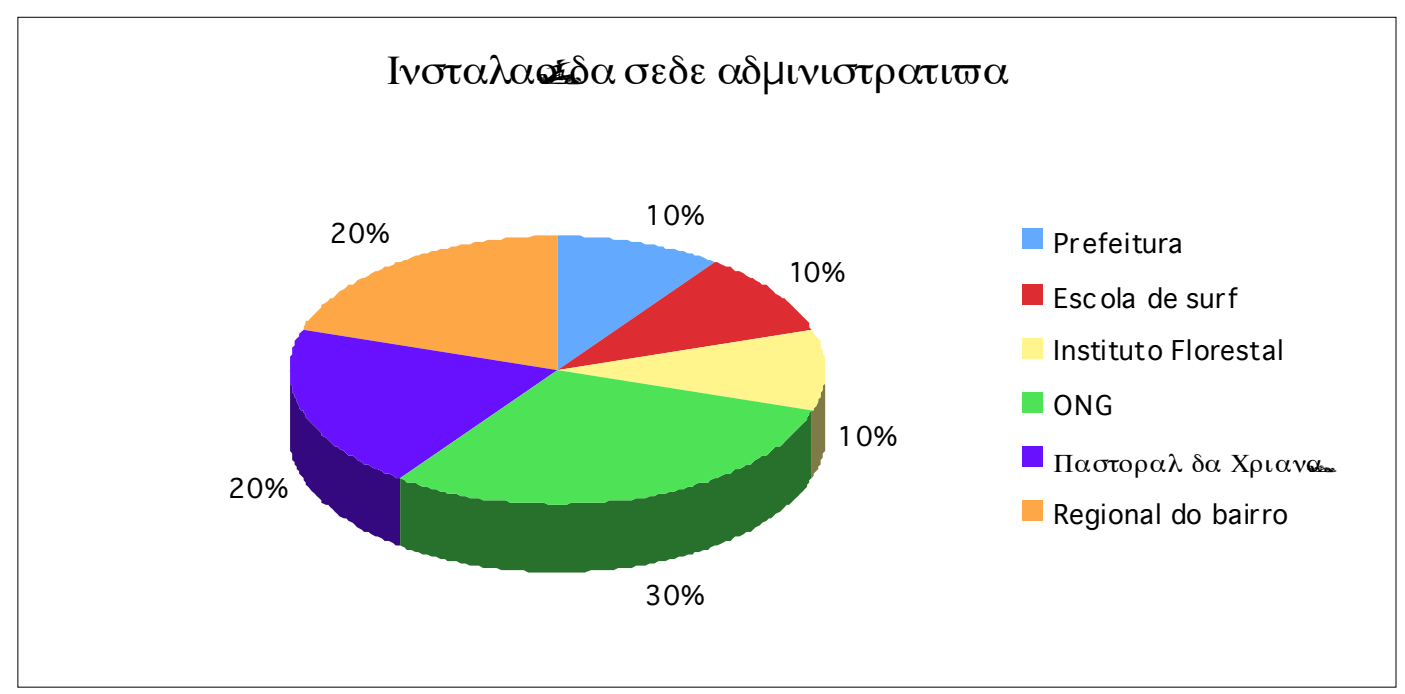

Figura 18 - Porcentagem de lugares citados onde pensou se instalar a sede administrativa do PEXJ de acordo com os moradores que não sabem da existência desta

Os moradores responderam como sendo atividades permitidas no PEXJ práticas relacionadas à recreação, à colaboração com a preservação da área e à educação. Do total de entrevistados cinco $(16,7 \%)$ não souberam responder à pergunta e apenas dois destes não sabiam que o Parque é protegido por lei. Um entrevistado $(3,3 \%)$ disse que atividade nenhuma é permitida, cabe ressaltar que esta é a única pessoa que já trabalhou na ONG "SOS Itaquitanduva". Do total de atividades citadas como permitidas, $18,75 \%$ delas são proibidas (Tabela 11). É importante mencionar que a prática de acampamento foi classificada como proibida, por constar na fase 1 do Plano de Manejo que essa atividade deve ser planejada e regulamentada, o que ainda não foi feito e por moradores terem identificado-a como tal. Entretanto o acampamento tem sido permitido pela polícia ambiental, com o argumento de que o Parque não está efetivamente instituído (dado obtido com a Polícia Ambiental).

Um morador citou que a prática de futebol depois de certo horário é permitida. Isso demonstra que a praia do Parque foi comparada com praias de acesso livre, onde a prática de esportes é restrita ao período noturno. A retirada de poucas porções de marisco ter sido citada como prática permitida demonstra o 
desconhecimento sobre a UC e as relações que as pessoas podem fazer por saberem apenas que área é protegida por lei.

O surf, por ter apresentado a maior porcentagem de citações, revela que esta é uma prática bastante difundida no território do Parque, principalmente na praia de Itaquitanduva, onde acontecem até mesmo campeonatos. A Tabela 11 mostra os erros e acertos quanto às atividades citadas como permitidas e foi elaborada levando em consideração a fase 1 do Plano de Manejo e o fato da unidade não estar efetivamente implementada.

Tabela 11 - Acertos e erros para as atividades citadas como permitidas na área do PEXJ (considerando o atual Plano de Manejo)

\begin{tabular}{|c|c|c|c|c|c|}
\hline \multicolumn{3}{|l|}{ ACERTOS $(81,25 \%)$} & \multicolumn{3}{|c|}{$\operatorname{ERROS}(18,75 \%)$} \\
\hline ATIVIDADES & $\mathbf{N}^{\circ}$ & $\%$ & ATIVIDADES & $\mathbf{N}^{\circ}$ & $\%$ \\
\hline Surfar & 14 & 35,9 & Pescar & 6 & 66,7 \\
\hline Caminhada & 3 & 7,7 & Pegar poucas & 1 & 111 \\
\hline Conservar & 2 & 5,1 & porções de marisco & 1 & 11,1 \\
\hline Jogar futebol & 2 & 5,1 & Pegar marisco & 1 & 11,1 \\
\hline Natação & 2 & 5,1 & Acampar & 1 & 11,1 \\
\hline Ir a praia & 2 & 5,1 & & & \\
\hline Jogar vôlei & 2 & 5,1 & & & \\
\hline Caminhada para conhecimento & 1 & 2,6 & & & \\
\hline Colaboração & 1 & 2,6 & & & \\
\hline Escalar & 1 & 2,6 & & & \\
\hline Lazer & 1 & 2,6 & & & \\
\hline Limpeza & 1 & 2,6 & & & \\
\hline Nenhuma & 1 & 2,6 & & & \\
\hline Pegar água & 1 & 2,6 & & & \\
\hline Piquenique & 1 & 2,6 & & & \\
\hline Tirar foto & 1 & 2,6 & & & \\
\hline $\begin{array}{l}\text { Todas que não agridam o meio } \\
\text { ambiente }\end{array}$ & 1 & 2,6 & & & \\
\hline Tomar banho & 1 & 2,6 & & & \\
\hline Trazer sacola da praia & 1 & 2,6 & & & \\
\hline TOTAL & 39 & 100 & TOTAL & 9 & 100 \\
\hline
\end{tabular}

Os moradores que responderam a questão sobre permissões no Parque foram questionados quan to a conhecerem ou já terem visto alguma pessoa praticando tais atividades, e todos responderam afirmativamente. Nove moradores (30\%) não 
foram questionados a respeito dessa pergunta, pelo fato de cinco não saberem quais atividades são permitidas, um ter respondido que não há nenhuma que seja, dois terem dito que é permitido conservar e um que qualquer atividade que não agrida o meio ambiente é permitida.

Em relação às atividades citadas como proibidas também foi elaborada uma tabela com os erros e acertos das menções (Tabela 12), nesse caso a porcentagem de erro foi aproximadamente cinco vezes menor quando comparada aos erros mencionados para as atividades permitidas, atingindo apenas 3,45\%. O menor percentual de erros para as atividades proibidas pode ser reflexo tanto de ações de fiscalização quanto da maior facilidade de inferir as proibições, uma vez que se trata de uma área natural. Quatro moradores $(13,3 \%)$ não souberam responder a pergunta, sendo que destes um sabia que o território do PEXJ é protegido por lei, mais uma vez percebe-se a falta de informações sobre a UC para a comunidade. Um morador, que não sabia que a área é protegida pela lei, citou a pesca como sendo proibida, isso em decorrência de seu conhecimento sobre pessoas que foram pegas pela fiscalização ao praticar tal atividade. O entrevistado que citou ser proibido pegar tronco do chão, fez essa menção por não ter podido pegar lenha para fazer uma fogueira (fora do Parque). Uma pessoa que mencionou ser proibido construir casas no território do Parque, afirmou que o IBAMA impediu a tentativa de construções. Nesses casos fica evidente que o conhecimento acerca das proibições decorre de ações de fiscalização.

Em relação à citação de que levar cachorro na praia é proibido percebe-se, como já detectado, a comparação da praia Parque com praias de livre acesso. Uma passagem interessante sobre ser proibido cortar árvores foi a seguinte:

- "Dizem que não pode tirar a árvore, mas ela vai cair na rede de luz, e aí? Eu corto mesmo."

Dois entrevistados $(6,7 \%)$ disseram que nenhuma atividade é proibida e outros dois que todas as atividades são proibidas, destes últimos um já foi voluntário da ONG e afirmou que a unidade está fechada. É importante ressaltar que oficialmente o Parque está fechado, uma vez que não há nada instituído manejando e gerindo seu uso, mas como observado isso não acontece na prática.

Tabela 12 - Acertos e erros para as atividades citadas como proibidas na área do PEXJ (Considerando que o PEXJ não está efetivamente implementado) 


\begin{tabular}{|c|c|c|c|c|c|}
\hline ATIVIDADES & $\mathbf{N}^{\circ}$ & $\%$ & ATIVIDADES & $\mathbf{N}^{\circ}$ & $\%$ \\
\hline Caçar & 13 & 23,2 & Não tem atividade proibida & 2 & 100 \\
\hline Pescar & 10 & 17,9 & & & \\
\hline Acampar & 5 & 8,9 & & & \\
\hline Jogar lixo & 5 & 8,9 & & & \\
\hline Desmatar & 4 & 7,1 & & & \\
\hline Cortar árvores & 3 & 5,4 & & & \\
\hline Construir casas & 2 & 3,6 & & & \\
\hline Pegar planta & 2 & 3,6 & & & \\
\hline Todas & 2 & 3,6 & & & \\
\hline Caçar pássaros & 1 & 1,8 & & & \\
\hline Cortar palmito & 1 & 1,8 & & & \\
\hline Matar bichos & 1 & 1,8 & & & \\
\hline Prejudicar o ambiente & 1 & 1,8 & & & \\
\hline Abrir trilhas & 1 & 1,8 & & & \\
\hline Levar cachorro na praia & 1 & 1,8 & & & \\
\hline Pegar marisco & 1 & 1,8 & & & \\
\hline Pegar tronco do chão & 1 & 1,8 & & & \\
\hline Queimadas & 1 & 1,8 & & & \\
\hline Retirar certas árvores & 1 & 1,8 & & & \\
\hline TOTAL & 56 & 100 & TOTAL & 2 & 100 \\
\hline
\end{tabular}

Dentre todas as atividades mencionadas, quatro aparecem na placa informativa da praia de Itaquitanduva (Figura 19), sendo estas, acampar, jogar lixo, cortar árvores e prejudicar o meio ambiente, no entanto nenhum dos entrevistados mencionou tal placa, mesmo assim essa parece ser uma fonte de informação.

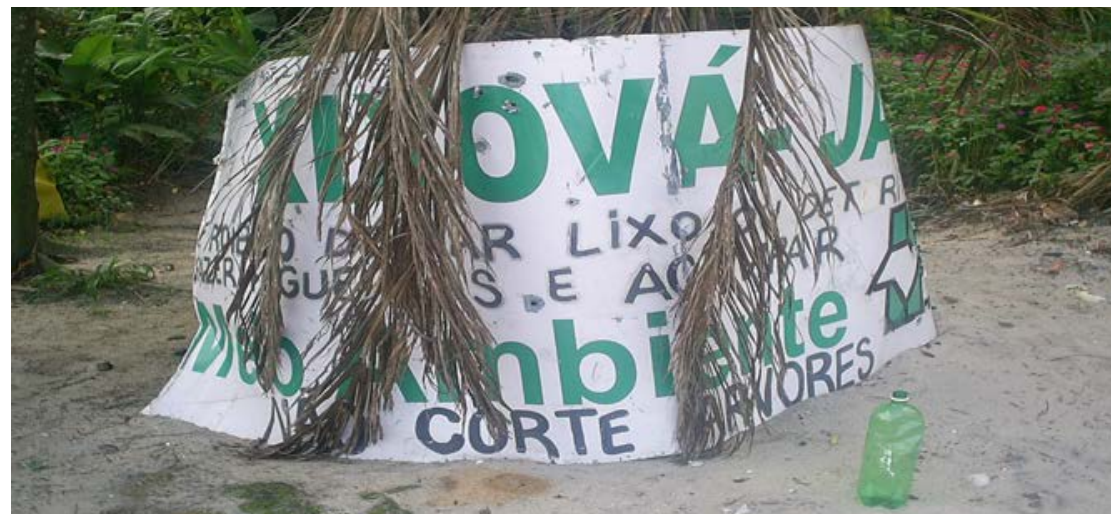

Figura 19 - Placa com informações sobre atividades proibidas 
Seis entrevistados não foram questionados sobre conhecerem ou terem visto pessoas praticando as atividades citadas como proibidas. Destes, quatro não sabiam o que era proibido e dois afirmaram não existir atividade des se gênero. Oito pessoas $(33,3 \%)$ responderam negativamente a essa questão, dentre estas, duas não visitam o Parque des de sua criação e três não o visita mais.

Dezesseis moradores $(66,6 \%)$ afirmaram ter conhecimento sobre o desenvolvimento das atividades proibidas na área do Parque, destes, um além de conhecer disse que as pratica, tendo citado a pesca e o acampamento. As outras atividades citadas foram: construção de casas, caça (de tatu e lagarto), descarte de lixo, matar animais, desmatamento, acampamento, queimada, corte de bambu e pesca. Algumas passagens interessantes sobre tais práticas:

- "Pessoas que usam drogas fizeram um barraco e eu destruí."

- "Davi Mendonça cortou a mata e escreveu seu nome com cal."

- "Já vi muitas pessoas que caçam e acampam."

- "Pescam direto, a polícia florestal vive pegando."

- “É o que mais acontece."

A última pergunta referente ao conhecimento dos entrevistados e a disponibilidade de informações refere-se a estes terem sido convidados para algum evento relacionado ao Parque, como reuniões, reuniões temáticas, palestras ou outros. Mais da metade dos moradores $(63,3 \%)$ disse nunca ter sido convidado, o restante, afirmou ter sido convidado, seja pela ONG (sete pessoas), pelo extinto Centro Comunitário, pelo projeto TAMAR, por amigos, por um candidato a vereador ou para participar de uma passeata, ambos citados por uma pessoa (Figura 20). O convite para a passeata não contou com a presença do entrevistado e esta manifestação dizia respeito à construção de um condomínio na área do Parque que, de acordo com o morador, teria sido embargado pelo IBAMA. Levantamentos de dados secundários não comprovaram que o projeto TAMAR tenha desenvolvido algum evento relacionado ao PEXJ, esta menção é passível de ser um engano, uma vez que é comum as pessoas confundirem as organizações associadas ao meio ambiente e suas verdadeiras funções. A única pessoa que mencionou o extinto Centro Comunitário foi o ex-presidente desta entidade. $\mathrm{O}$ fato da maioria dos entrevistados nunca ter sido convidada, demonstra tanto baixa operância da administração do Parque, quanto da ONG, que é relacionada ao Parque, nas ações 
de informação à comunidade e envolvimento desta. É importante ressaltar também que nunca o convite foi feito pelo IF, órgão gestor da unidade, nem mesmo pelo IBAMA, que foi reconhecido por alguns moradores como tento ligação com o Parque. Esse fator é um agravante que reforça a baixa operância da gestão do Parque sobre a disponibilização de informações.

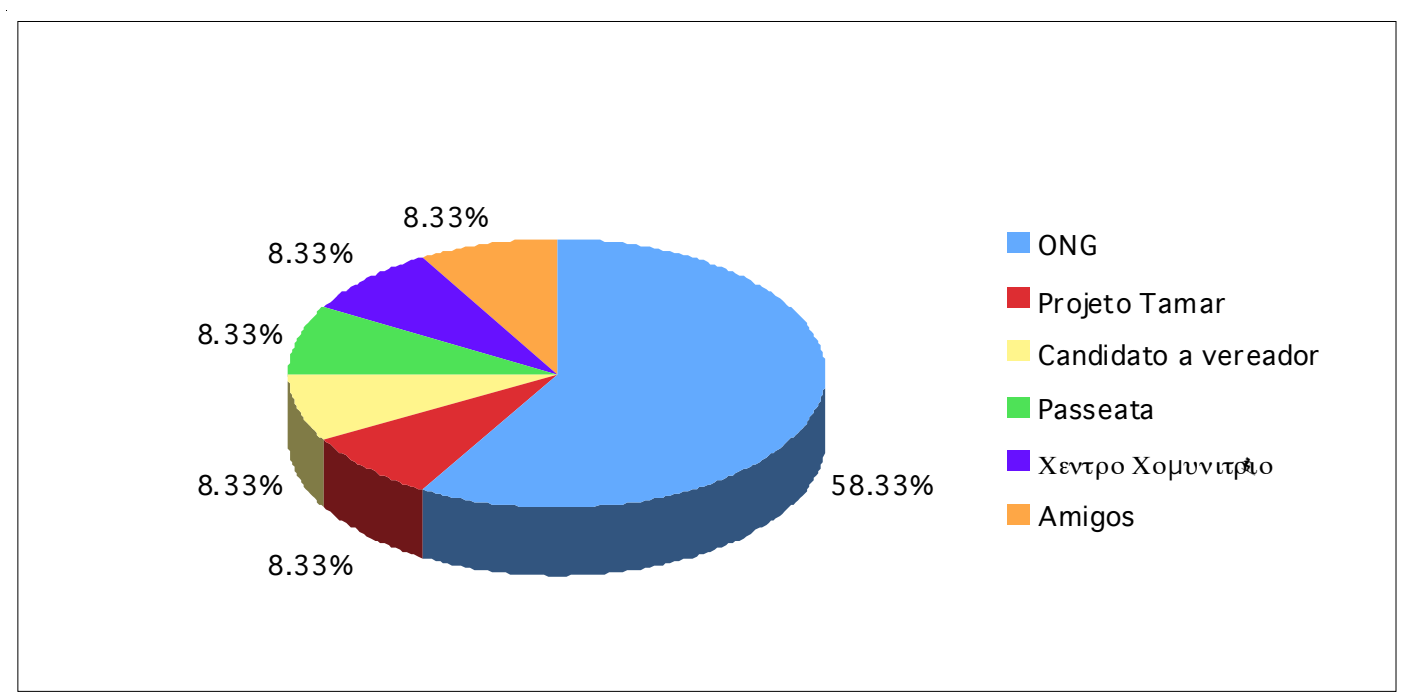

Figura 20 - Porcentagem de convites para participar de eventos relacionados ao PEXJ quanto a quem convidou

\subsubsection{Opinião dos moradores}

A primeira questão deste bloco refere-se a o que o morador acha da divulgação de informações relacionadas ao Parque para a comunidade, classificando-a em boa, regular e ruim.

Dezoito entrevistados (60\%) disseram que a divulgação é ruim. Tal classificação está de acordo com o baixo conhecimento das pessoas sobre o Parque e decorre da ausência de atuação do órgão gestor, assim como demonstram os argumentos. Esse resultado condiz com o encontrado por Oliveira (2006) para a organização da comunicação no PEXJ que, de acordo com esse autor, é praticamente inexistente. Abaixo seguem alguns argumentos:

- “Não tem divulgação." (12 citações)

- "Seria interessante se tivesse."

- "Seria bom se tivesse nas escolas para as crianças."

- “Muitos não têm consciência por falta de informação.”

- "Seria bom se tivesse para o povo participar."

Os moradores que qualificaram a divulgação como regular, perfazem $20 \%$ 
do total e disseram que muitas pessoas não sabem sobre o Parque e que não tem muita divulgação. Apenas três moradores (10\%) disseram achar boa a divulgação de informações, uma vez que as pessoas conservam o Parque. Outros três não souberam responder a pergunta (Figura 21).

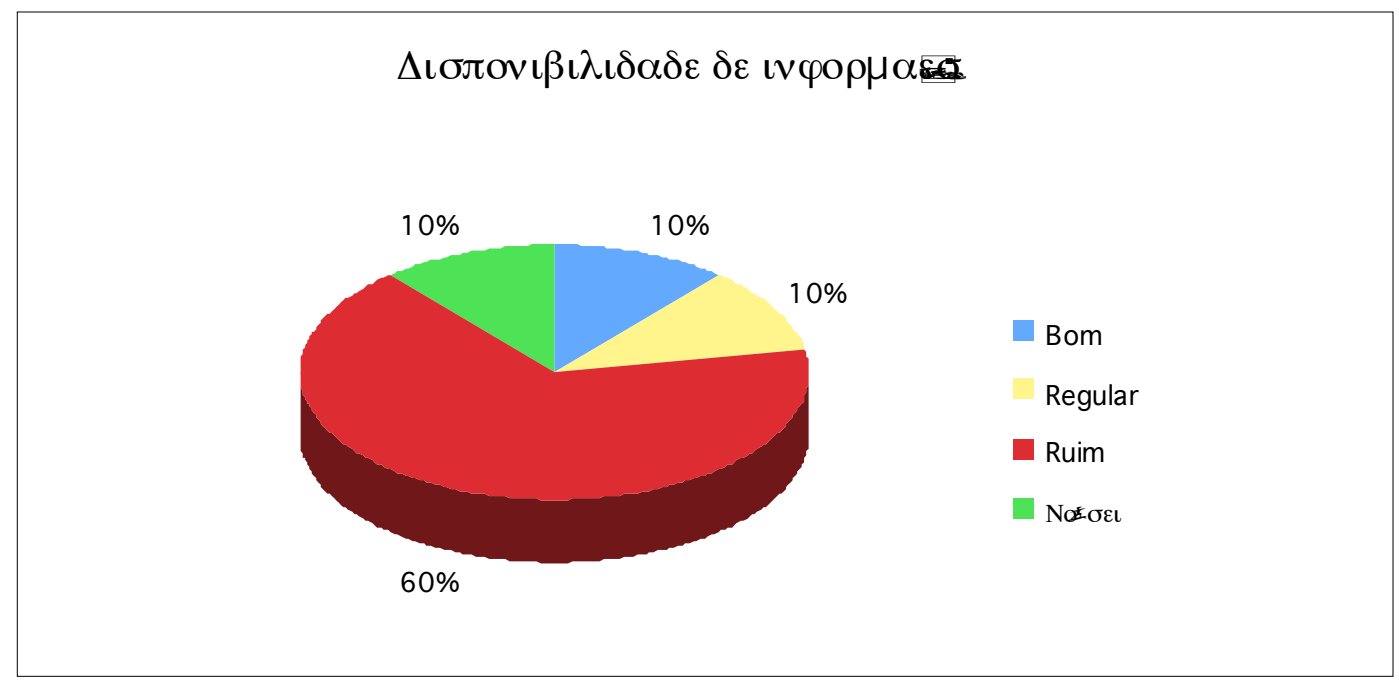

Figura 21 - Classificação da disponibilidade de informações para a comunidade e respectivas porcentagens

Apenas dois entrevistados conhecem o diretor do PEXJ, um deles disse que o relacionamento com este é ruim, pois não gosta dele e o outro disse ser bom. Os outros 28 moradores não se relacionam com o diretor, sendo que 26 destes nem se quer sabiam que o Parque tinha uma pessoa ocupando esta função. Um morador que sabia que o Parque tem um diretor fez a seguinte menção:

- "Nunca ninguém viu o diretor, se depender dele ninguém sabe de nada."

Essas duas perguntas de opinião junto às do bloco anterior só vêm ressaltar o estado de falta de informação à sociedade civil, o que também foi demonstrado por Oliveira (2006) e perdura até hoje. Tal situação pode ser uma forçante da baixa informação ambiental dos moradores. Roncaglio et al. (2004), dispondo sobre os benefícios que as informações proporcionam a uma sociedade, afirmam que "em todas as épocas, a informação apresentou-se como um instrumento importante para a sociedade, seja para a sua organização e funcionamento, para o aperfeiçoamento das suas instituições, para o exercício do poder, para a conquista e ampliação de direitos". Como observado por Oliveira (2005) e Gomes (2002) a ausência de informação a respeito das UC para as comunidades gera conflitos de conservação e preservação para a primeira. 
Considerando não só as mudanças que informações podem conferir à sociedade e à unidade, Hauff (2004) menciona que a melhoria de informação e orientação são umas das solicitações para a melhoria do relacionamento entre a unidade e a comunidade. Deste modo a otimização do processo informativo ao qual a comunidade do bairro Japuí está submetida seria de relevante importância para o cumprimento dos preceitos sócio-ecológicos do Parque por parte dos moradores. As melhorias propostas por Hauff (2004) também poderiam ser alcançadas com a implementação do Conselho Consultivo do PEXJ, assim a gestão participativa, baseada em processos informativos prévios seria uma maneira de atingir os objetivos conservacionistas do Parque.

Quando questionados sobre como qualificam a gestão, 46,7\% dos entrevistados (Figura 22) responderam que é ruim com alguns argumentos:

- "Não cuidam direito."

- "Falta informação."

- "Vem barco de arrasto perto da praia."

- "Quem cuida é a comunidade."

- "Só ficam na prainha."

- $\quad$ "Quer trabalhar tem que saber, se tem sempre que acompanhar de perto cadê eles?"

Os moradores que disseram que a gestão é regular perfazem 23,3\% (Figura 22) e deram os seguintes argumentos:

- “As pessoas não tem acesso à informação."

- "Deveria ser mais cuidado."

- "Falta policiamento."

- "Preocupam-se mais com os animais do que com a praia."

Os entrevistados que disseram que a gestão é boa são 26,7\% (Figura 22) e os argumentos foram:

- "Não temos reclamação."

- "Não deixam invadir."

- “Não trazem mais terra, bambu, bichos e árvores."

- “É boa, mas poderia ser melhor." Apenas uma pessoa (3,3\%) não soube responder a questão (Figura 22 ). 


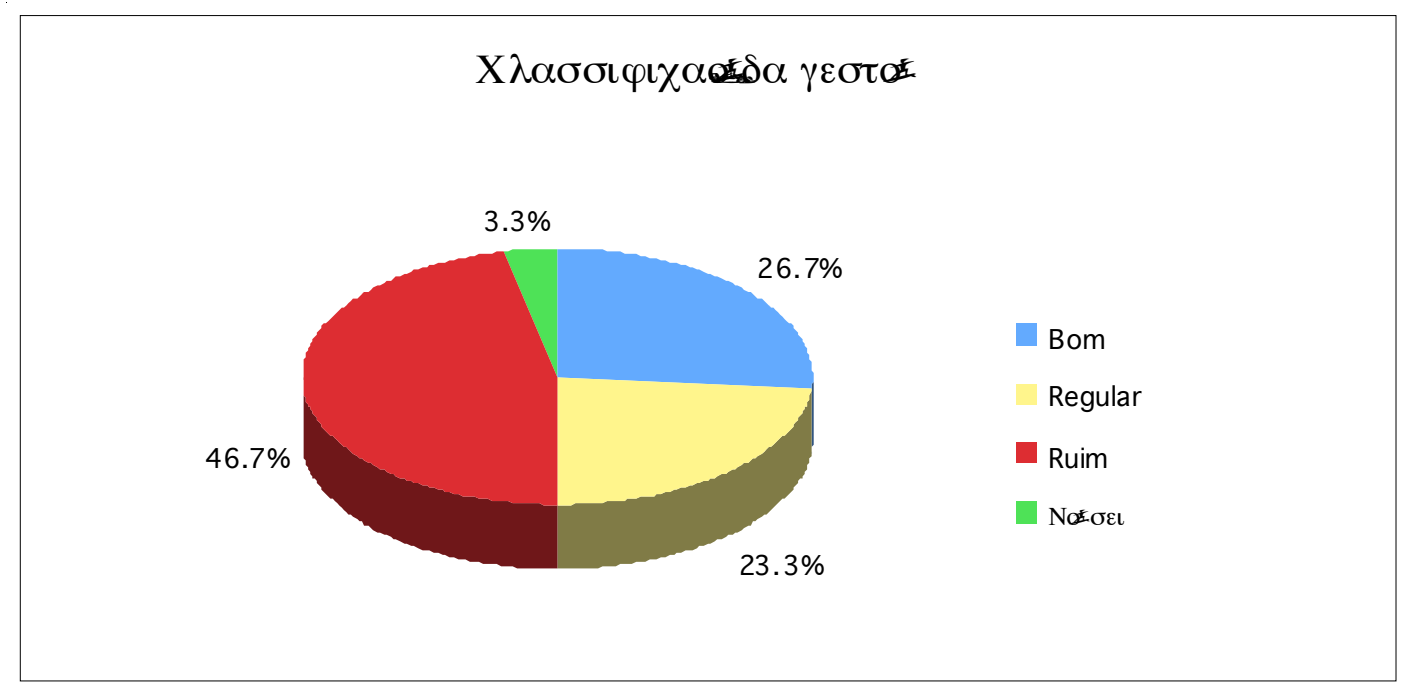

Figura 22 - Classificação da gestão do PEXJ e respectivas porcentagens

Sobre o relacionamento que a comunidade mantém com o território do Parque, 60\% dos entrevistados classificou-o como bom, 23,3\% como regular e $13,3 \%$ como ruim. Apenas uma pessoa $(3,3 \%)$ não soube responder a pergunta (Figura 23).

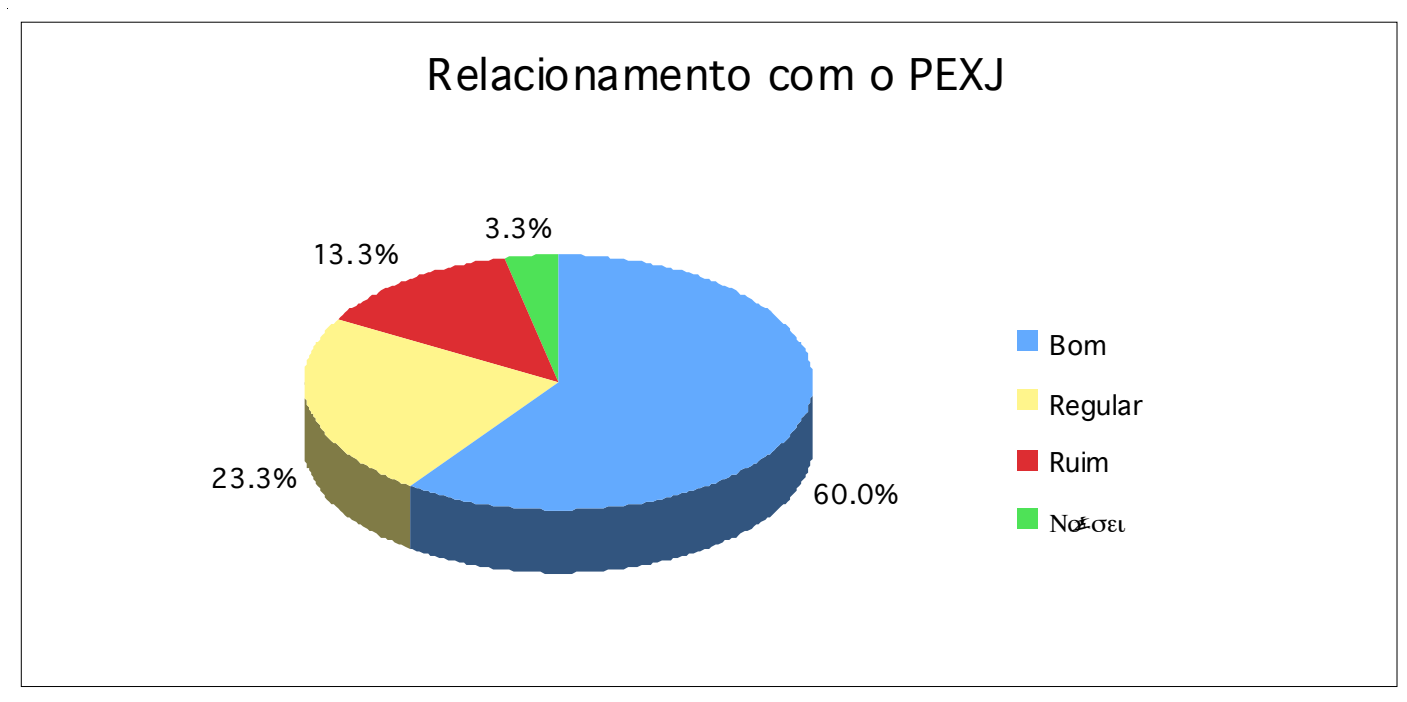

Figura 23 - Classificação do relacionamento da comunidade com o território do PEXJ e respectivas porcentagens

Alguns argumentos para a primeira classificação foram:

- “O pessoal tem consciência." 
- "Denunciam queimadas."

- "Cuidam da trilha.”

- "Não deixam estragar."

- "Não tiram nada da mata."

Os argumentos para a classificação do relacionamento como regular foram:

- "Deixam lixo."

- "Os jovens cuidam."

- "Podia ser melhor."

Os argumentos referentes ao relacionamento ser ruim foram:

- "Destroem o Parque."

- “Fazem o que querem."

- “Jogam lixo.”

- “Cortam árvores."

Quando questionados sobre a existência de algum órgão ou alguém que represente os interesses da comunidade à administração do Parque, mais da metade dos entrevistados $(56,7 \%)$ disse que não existe; $16,7 \%$ mencionaram a ONG "SOS Itaquitanduva"; $10 \%$ mencionaram uma moradora do bairro, Dona Inês; 3,3\% disseram que o Rogério, ex-membro da ONG e 13,3\% não soube responder. Dentre os que não souberam responder, um morador disse que antes o Serginho, exmembro da ONG representava, e que agora a Dona Inês deve fazer esse papel, outro morador também mencionou que o Rogério representava.

Vinte e três entrevistados $(76,7 \%)$ fizeram críticas e/ou deram sugestões relativas ao Parque, o restante disse não ter o que falar. Nem todas as sugestões dadas podem ser aplicadas no PEXJ, sendo estas, que se permitisse a construção de um condomínio fechado e que houvesse a plantação de árvores frutíferas. Estas sugestões demonstram o desconhecimento sobre a UC.

Parte dos resultados apresentados para esta pergunta foi retirada de comentários feitos pelos moradores no decorrer da aplicação do questionário, uma vez que tais comentários constituem informações importantes a serem consideradas.

Sugestões de informação (42,9\% das sugestões):

- "Ter um lugar para explicar pra quem não entende."

- "Fazer trabalho com as crianças do bairro."

- "Fazer uma área para as pessoas conversarem sobre o Parque." 
- “Mais divulgação, o Japuí aparece através do Parque, poderia melhorar o bairro."

- "Precisa de palestras sobre a importância do Parque."

- "Precisa urgentemente de mais informação, podiam conversar com a dona do sobrado (casa da Pastoral da Criança, onde já esteve instalada a sede do PEXJ) para dar palestras lá.”

- “Que diretores, secretários fizessem reuniões, palestras nas escolas para que o povo tivesse mais consciência e responsabilidade."

- "Ter mais atividades voltadas para a população."

Considerando as passagens anteriores, fica claro que alguns moradores julgam necessário melhorar a disponibilidade de informações para a comunidade. Para isso, assim como ressaltado por um dos entrevistados, se faz necessário a criação de um local que centralize e forneça as informações. Uma estratégia seria a gestão do PEXJ estabelecer parcerias com instituições que pudessem colaborar com a divulgação de informações, seja ministrando palestras nas escolas, ministrando aulas de educação ambiental e desenvolvendo trabalhos e pesquisas junto à comunidade.

Sugestões de gestão $(28,6 \%)$ :

- "Que viesse uma comissão pra olhar e saber o que fazer, não só querer tudo mastigado."

- "Fazer coisas bonitas para chamar pessoas para visitar.”

- “Órgão ou ONG competente para melhorar."

- "Quando tem campeonato de surf vender coisas para levantar dinheiro para preservar a área, fazer bingo, chá."

Sugestões de fiscalização e segurança (19\%):

- "Mais interesse pela prefeitura de colocar guardas para a proteção de turistas, as pessoas do bairro não gostam que venha gente de fora."

- "Que tivesse mais fiscalização no lado do Japuí, pois tem muitas mortes." Sugestão de infra-es trutura $(9,5 \%)$ :

- "Limpeza e manutenção da trilha, por que é difícil ir com criança." Algumas das críticas

- "A respeito da administração se ela existe mesmo tem que tratar com o pessoal do Japui que é diretamente relacionado ao Parque.” 
- "Quanto à proibição da pesca com vara."

- "Falta de limpeza."

- "Vir gente de São Paulo ou do Rio de Janeiro pra cá e querer fazer alguma coisa é difícil."

- "A direção agora é ruim."

- "Não pode pescar só na temporada (...) se é lei tem que ser sempre."

- "Falta mais segurança, parceria com a prefeitura."

Essas críticas, assim como as sugestões demonstram que os moradores estão descontentes com a maioria dos fatores que cercam o Parque, dentre estes a fiscalização, segurança, infra-estruturas, informação, as práticas de gestão e com a administração. Tal descontentamento pode ser mais um reflexo do desconhecimento dos moradores em relação ao Parque, da ausência de comunicação entre o PEXJ e a comunidade e da ausência histórica de atuação do poder público no bairro, como será detalhado posteriormente.

Os itens que se seguem não são respostas a nenhuma pergunta e também não são criticas nem sugestões, mas são apresentados, pois revelam a consciência de alguns entrevistados em relação ao Parque.

- "Todos deviam zelar, cuidar para no futuro os filhos e netos contarem o mesmo".

- "Os primeiros a cuidar têm que ser a comunidade."

- "É importante educar as crianças."

\section{4 . 4 .Perfil da ONG "SOS Itaquitanduva"}

Esta entidade existe de maneira informal há cerca de 30 anos tendo sua existência formalizada apenas no ano de 2000. No final de 2007 seus membros foram substituídos por novos membros representantes. A ONG tem projetos direcionados ao meio ambiente, à prática de exercícios físicos e ao desenvolvimento profissional da comunidade de entorno do Parque, principalmente aos moradores do bairro Japuí, onde a sede da organização se instala. Dentre os projetos estão cursos profissionalizantes e aulas de surf, de artes marciais, lamba-aeróbica, educação ambiental e de artesanato. Destes, apenas o de educação ambiental foi implantado e acontece todos os sábados na sede da ONG, sendo direcionado para crianças. As aulas são ministradas por uma professora voluntária que também é professora 
integrante da Coordenadoria de Educação Ambiental do município de Praia Grande. Já no início da nova gestão, membros da ONG buscaram parcerias com a UNESP e com a gestão do PEXJ, esta última não foi bem sucedida, muito por conta da última gestão da ONG que mantinha um relacionamento conflituoso com a administração do Parque.

Foram entrevistados o presidente, o vice-presidente e a tesoureira da ONG "SOS Itaquitanduva".

\subsubsection{Caracterização e relacionamento dos membros da ONG com o território}

A média da idade dos entrevistados é de 27 anos, variando de 22 a 34. Dois apresentam Ensino Superior Completo, nas áreas de Educação Física e Comércio Exterior e o último apresenta o Ensino Médio Completo. O vice-presidente e a tesoureira estão na ONG desde novembro de 2007 e o presidente desde janeiro de 2008 .

Quanto ao relacionamento com o PEXJ todos os membros visitam o Parque com alta freqüência (mais de uma vez por mês) e desenvolvem atividades de lazer, como surf, visita à praia e trilhas. Apenas o presidente mencionou fazer limpeza da praia de Itaquitanduva.

\subsubsection{Informação ambiental}

Quando questionados sobre conhecerem algum exemplar da flora e fauna do Parque a maioria das citações foi de mamíferos, com $70 \%$ do total, sendo estes, bicho preguiça, gato do mato, raposa, macaco e golfinho. Foram citadas aves (20\%), sem descriminação de nenhuma e apenas um exemplar de réptil, a tartaruga, com $10 \%$ das citações.

As diferenças do Parque com outras áreas verdes dizem respeito à Conservação/Preservação, com $75 \%$ do total de diferenças citadas, sendo estas o fato de o território ser totalmente preservado, da fauna e flora serem mais ricas e da presença de uma praia limpa. Para um dos entrevistados a diferença é que ele tem acesso a essa área de natureza. Em algumas área do PEXJ nota-se a presença de espécies exóticas, invasoras e trechos estagnados em relação às dinâmicas sucessionais, deste modo não se pode afirmar categoricamente que o Parque é totalmente preservado. Essa afirmação demonstra um baixo conhecimento a cerca 
do ecossistema original do Parque.

A maioria dos problemas mencionados pelos entrevistados, $54,5 \%$ do total, diz respeito à Conservação, sendo estes que a visitação excede a capacidade de carga, a prática de tráfico de animais silvestres, de acampamento, de pesca de rede, o desmatamento e a ocorrência de incêndios. Os problemas classificados como de Segurança $(18,2 \%)$ foram relativos ao uso do território do Parque por marginais para fuga e a presença de usuários de drogas. Em relação à Ocupação um entrevistado mencionou que há obras dentro do Parque, em relação à Limpeza, a ocorrência de lixo e quanto à Gestão, a falta de monitoramento. Esses últimos problemas perfazem juntos $27,3 \%$ do total, contribuindo com $9,1 \%$ cada.

As sugestões de medidas corretivas dos problemas foram as que se seguem, sendo que apenas uma, ter monitores, foi citada por dois entrevistados:

- Autoridades responsáveis fazerem suas funções.

- Colocar lixeiras

- Ter monitores

- Ter guarita

- Ter cancela

- Ter orientação aos usuários

- Integração entre todos os e a ONG para preservar o Parque

Analisando as respostas dos componentes da ONG para as questões apresentadas acima, percebe-se que estes não saem do senso comum observado para os moradores. Deste modo a informação ambiental desses dois segmentos segue o mes mo padrão de baixo conhecimento.

Em relação aos benefícios que o Parque traz para a comunidade, os entrevistados mencionaram apenas a possibilidade de benefícios futuros, o que demonstra que estes não percebem os benefícios já proporcionados em relação aos bens e serviços prestados pelo meio ambiente. Um entrevistado disse que o Parque poderia formar monitores ambientais e deste modo contribuir para a fonte de renda da comunidade carente. Outro membro da ONG disse que no estado que o Parque está não traz benefícios, no entanto pode ser de importância cultural, social e ambiental. $\mathrm{O}$ último entrevistado disse que se a unidade for corretamente utilizada trará benefícios.

É importante ressaltar que de todas as pessoas que responderam aos 
questionários apenas uma, um membro da $\mathrm{ONG}$, mencionou que a unidade poderia trazer benefícios econômicos à comunidade. Segundo Hauff (2004) “a implementação das unidades de conservação - principalmente de suas funções de proteção, manejo de recursos, administração e manutenção, pesquisa e, principalmente, de uso público - facilita a aceitação de sua existência por parte dos moradores por oferecer oportunidades de trabalho lícito e melhores perspectivas de renda e segurança”. Assim, seguindo o mencionado por essa autora, a implementação de certas práticas no PEXJ resolveria alguns dos problemas incidentes sobre este, como por exemplo, conflitos com a comunidade, a falta de envolvimento desta, tanto na gestão e manejo da área quanto na falta de segurança no território. Além disso, poderia diminuir o sentimento de "abandono" dessa comunidade perante o município, ao passo que se o Parque passasse a ser reconhecido por seus usos públicos e tais usos fossem manejados pelos moradores do bairro, certamente estas pessoas se sentiriam prestigiadas e reconhecidas. Tal reconhecimento também poderia advir da participação na gestão da área, não apenas no manejo. Firmando uma gestão participativa com o Parque, a comunidade teria maiores e melhores possibilidades de se inserir em outros processos de gestão pública, ao passo que adquiriria experiências de participação e governança.

Apenas um entrevistado acha que o Parque traz prejuízos para a comunidade, uma vez que a área é economicamente improdutiva, mal freqüentada e perigosa. Este também mencionou o fato da praia não contar com salva-vidas e a ocorrência de afogamentos. Outra entrevistada disse que a população é quem pode trazer prejuízos ao Parque, uma vez que não é bem informada e faz usos incorretos.

\subsubsection{Conhecimento sobre a UC e disponibilidade de informações}

Um membro da ONG respondeu que todas as atividades são permitidas no Parque, uma vez que este não está efetivamente implementado. Os outros dois disseram que nenhuma atividade é permitida, no entanto estes não agem de acordo com essa afirmativa, uma vez que freqüentam o Parque para práticas de lazer. Tal dubiedade demonstra o desconhecimento dessas pessoas sobre as atividades permitidas e proibidas.

Quando questionados sobre quais são as atividades proibidas, um entrevistado respondeu todas, um respondeu a caça, a pesca e retirada de plantas e o terceiro disse o seguinte: “As 'porteiras' ficam abertas para quem quiser entrar e 
fazer o que quer." Todos os membros da ONG disseram conhecer ou terem visto pessoas praticando as atividades proibidas. Um dos entrevistados ainda ressaltou que o uso de drogas, como a maconha, acontece como se fosse "legalizado" no Parque.

Dois dos entrevistados disseram nunca terem sido convidados para reuniões relativas ao Parque, sendo que um deles mencionou que para solicitarem uma reunião com a administração da unidade precisam encaminhar um oficio à mesma. $\mathrm{O}$ presidente da instituição disse ter sido convidado por amigos para o desenvolvimento da fase 2 do Plano de Manejo. Mais uma vez o convite não foi feito pelo órgão gestor da unidade.

\subsubsection{Opinião dos membros da ONG}

Quando questionados sobre o que acham da divulgação de assuntos do Parque para a comunidade as respostas foram unânimes, classificando-a como ruim. Os argumentos foram que as únicas placas foram colocadas pela ONG, o que de acordo com Oliveira (2006) não procede e que seria in teressante se tivesse.

Dois dos membros da ONG classificaram suas relações com o gestor do Parque como ruim, sendo que um enfatizou que o relacionamento é péssimo, o outro disse que na tentativa de uma conversa aconteceu uma discussão. O presidente na ONG não conhece o gestor da unidade e foi o único que disse que a relação ONG com a administração do Parque é boa. Os outros dois entrevistados classificaram esse relacionamento como ruim, argumentando que é um "pé de guerra" e que para qualquer coisa que a ONG tente fazer a administração do Parque coloca empecilhos, citando como exemplo um projeto de Educação Ambiental que teria sido vetado.

A gestão do Parque foi classificada como ruim e regular. Para o primeiro caso argumentou-se que o Parque está abandonado e que o atual gestor não tem preparo para ocupar tal cargo. Para a qualidade de regular da gestão argumentou-se apenas que esta deixa a desejar. Um entrevistado não classificou a gestão, pois disse que ela não existe, assim não pode falar se é boa ou ruim.

Essas quatro questões demonstram mais uma vez a existência de conflito entre a ONG e o PEXJ. De acordo com AS/GESET (2001) a noção de coresponsabilidade implica em reconhecer, entender e encontrar formas de relacionamento entre agentes com lógicas distintas de atuação em torno de objetivos comuns, sem perda de identidade e desvio de suas missões institucionais. Sendo 
assim, tais conflitos tenderiam a se diluir dando lugar a uma parceria positiva entre as instituições, no entanto, essa situação não é observada entre a ONG e o PEXJ. Isso, somado ao fato do direito de participação da ONG não ser reconhecido pela direção do Parque, só faz aumentar a situação de conflitos entre esses dois segmentos. De acordo com Falconer (1999), ao passo que tal reconhecimento acontece, devem-se definir estratégias, atribuir responsabilidades, obter e alocar as competências organizacionais e pessoais necessárias.

Dois membros da ONG qualificaram o relacionamento da comunidade com o Parque como bom, dizendo que as pes soas têm grande carinho pela área e que não é necessário organizar os mutirões de limpeza, pois todos ajudam. Ambos mencionaram que pela falta de informação muitas vezes os moradores não sabem como utilizar a área do Parque. Um qualificou este relacionamento como regular, pois poucos moradores freqüentam o Parque.

Os três entrevistados consideraram que a ONG é uma entidade que representa os interesses da comunidade perante a administração do PEXJ, no entanto apenas cinco moradores atribuem a esta entidade tal papel. Além disso, quando os membros foram questionados sobre a procura da comunidade para tratar de assuntos do Parque, adquiriu-se respostas que parecem ir contra a afirmativa de que a ONG é representativa, sendo estas:

- "Poucas pessoas que já eram envolvidas procuram, outras procuram pelas atividades."

- "Tem envolvidos que surfam e ajudam, mas a maioria não."

Cabe ressaltar que a Dona Inês, citada por alguns moradores como sendo uma pessoa que faz o intermédio entre o PEXJ e a comunidade e que é uma das principais lideranças locais, declarou o seguinte:

- "Dizem que tem uma ONG nova (referindo-se a nova gestão da "SOS Itaquitanduva"), dizem que ela inaugurou a sede, mas ninguém ficou sabendo de nada, nem onde está."

Ainda, o fato dos próprios membros da ONG terem classificado seus relacionamentos e o desta entidade como ruim com a administração do Parque parece ser um agravante para que tal representatividade não seja realmente efetiva.

As considerações finais em relação ao PEXJ feitas pelos membros da ONG foram: 
- "Cada um com sua parcela de responsabilidade, temos que nos unir para alcançar os objetivos."

- "Que as pessoas olhem a ONG com outros olhos, pois o ideal é a preservação do Parque. Quem quiser é só che gar e ajudar."

- "Tem que ter guarita, informação, monitoramento, lixeira..."

\section{4 . 5 . Avaliação de políticas públicas}

\subsubsection{Instalação da rede elétrica}

A instalação da rede elétrica no bairro aconteceu apenas no final da década de 60, até então as famílias faziam candeeiros a base de querosene para ter luz nas casas. Esta condição motivou reivindicações por parte dos moradores, que não foram prontamente atendidos, além de terem sido boicotados durante uma das manifestações (retirada dos ônibus de circulação do bairro pela prefeitura). Considerando esta mobilização da comunidade para aquisição do serviço elétrico a pertinência dessa política foi alta. A eficácia desta política foi baixa pelo período de uma década, isso em função da qualidade do sistema, assim como demonstra a fala de uma moradora:

- “A iluminação era péssima, bem fraquinha, os postes eram todos de madeira."

Depois disso as condições de iluminação melhoraram, atendendo aos objetivos. A coerência dessa política foi baixa enquanto a voltagem disponível era apenas 220 e de acordo com a fala acima.

Os impactos, mesmo quando a política ainda era pouco eficaz, certamente foram positivos. Não é possível afirmar categoricamente que tal política tenha estimulado a ocupação da área, no entanto é bastante provável que tenha havido esse efeito, uma vez que tal infra-estrutura passou a existir, melhorando a condição do bairro.

\subsubsection{Aterro das ruas e implementação de comportas}

Como já mencionado era freqüente a ocorrência de enchentes no Japuí, o que era causado pela maré de enchente e não pela chuva. De acordo com os moradores quando esses eventos ocorriam o acesso ao bairro e a saída deste eram dificultados, sendo necessário o uso de barcos. Além disso, era comum o abandono 
temporário das residências que ficavam inabitáveis pela entrada de água, que eventualmente causava perdas de bens materiais. $O$ aterro das ruas e a implementação de comportas ocorreram entre meados da década de 60 e a de 70 .

A eficácia dessa política é alta, considerando que o objetivo era conter as enchentes, o que de acordo com uma moradora, nunca mais aconteceu com a implantação de comportas. Caso o aterro tenha sido feito com dejetos provenientes da Cosipa ou de lixo de Santos, alguns impactos negativos podem ter ocorrido, entre estes ambientais, econômicos e de saúde pública, as sim como sugerem as passagens abaixo:

- "Eles jogavam a escoria da Cosipa, subia uma poeira terrível preta, aquilo dava tosse na gente, os brônquios, o nariz ficava terrível."

- “Como jogaram lixo aqui 10 anos e nós construímos as casas em cima do lixão quando apodrecia afundava a gente tinha sempre que colocar aterro."

Outros impactos negativos referentes à saúde podem ter ocorrido em regiões adjacentes pela drenagem de tais resíduos.

Os efeitos positivos dessa política foram a facilitação do deslocamento no bairro, uma vez que não era mais necessário fazer o transporte de barco, e a reversão dos alagamentos, assim como demonstra a fala abaix o:

- “As ruas foram todas aterradas, suspenderam, colocaram comportas e nós não temos o problema de enchente."

Outro impacto positivo que certamente aconteceu é a melhoria da saúde pública, uma vez que a não ocorrência de enchentes diminui doenças de veiculação hídrica. Mais uma vez, esta política perfaz o avanço de infra-estrutura no bairro, o que também pode ter induzido a ocupação.

O objetivo dessa política pública, considerando ser conter as enchentes, é bastante pertinente com a realidade local e a necessidade social. Caso o aterro tenha sido feito com os resíduos da Cosipa fica clara a incoerência dessa política pelo uso de material inadequado.

\subsubsection{Implantação do sistema de água}

Até o final da década de 70 o bairro ainda não dispunha de abastecimento de água, as famílias utilizavam as bicas, tanto para coletar água potável, como para tomar banho e lavar as roupas. O processo para implantação dessa política pública, 
que também contou com reivindicações dos moradores, o que caracteriza sua alta pertinência. A eficácia dessa política foi alta.

Esta política trouxe impactos positivos ao passo que água potável promove melhoria na saúde das pessoas e visto as dificuldades que as famílias tinham para adquirir água foram sanadas. Como impacto negativo tem-se o aumento da geração de esgoto, pois há um estímulo à maior utilização da água, tal situação ainda traz maiores prejuízos pelo fato de o sistema de captação de esgoto ainda não ter sido implantado no bairro na época de implantação da água. Um efeito indireto dessa a diminuição do uso de água da bica do PEXJ. Não foi possível analisar a coerência dessa política pela falta de indicadores.

\subsubsection{Criação da EMEIEF "Maria Mathilde de Santana"}

No final da década de 70 aconteceu a criação da EMEIEF "Maria Mathilde de Santana”. Esta política não teve alta eficácia, uma vez que esta escola não apresentava o Ensino Fundamental completo e as crianças ainda precisavam ir estudar na área insular de São Vicente ou no município da Praia Grande. Por este mesmo motivo a coerência também foi baixa. Os impactos gerais foram positivos, uma vez que a escola existente antes desta apresentava menor capacidade de alunos. A pertinência dessa política foi alta, visto que muitas crianças tinham que sair do bairro para estudar, assim como demonstra a fala abaixo:

- “As crianças tinha quem ir estudar em São Vicente."

\subsubsection{Inauguração da Ponte do Mar Pequeno}

Em 1980 foi inaugurada a Ponte do Mar Pequeno. Considerando que o objetivo dessa obra era melhorar o acesso à região da Baixada Santista, sua eficácia foi alta.

Esta obra promoveu a facilidade de acesso ao Vale do Ribeira e ao Litoral Sul e a melhoria do tráfego na região, desobstruindo a Ponte Pênsil e seus acessos. Pela melhor acessibilidade, permitiu um maior desenvolvimento do bairro. As falas a seguir demonstram tais impactos:

- “Aí depois que o Paulo Maluffez essa ponte melhorou 100\% o Japuí." 
- "Quando fizeram a ponte nova nós ficamos muito agradecidos ao Paulo Maluf, por que deu uma vazão muito grande."

- "Essa ponte favoreceu a exportação de chuchu."

Por outro lado a construção da ponte induziu novas ocupações, tornando a área alvo da especulação imobiliária e do turismo de veraneio, típico nos municípios da Baixada Santista, tendo como atrativo diferenciado a área do PEXJ. A fala a seguir mostra o aumento da ocupação no bairro:

- "Depois da construção de ponte (começou a ter muita gente no bairro), por que ai abre-se um leque."

Os prejuízos também dizem respeito às atividades de comércio desenvolvidas por moradores nas imediações da Ponte Pênsil, que passaram a ser menos rentáveis. Houve grande desemprego, pois o grande contingente de ambulantes que atuava nas filas ficou sem atividade, de acordo com a seguinte menção feita por uma moradora:

- "Existem coisas que temos que perder para ganhar, o povo perdeu o emprego e ganhou a liberdade de ir e voltar sem precisar ficar 4, 5, praticamente 10 horas na fila pra chegar em São Vicente."

A pertinência dessa política é alta considerando-se a situação do acesso dificultado a algumas regiões da Baixada Santista, feito unicamente pela Ponte Pênsil. No entanto considerando o bairro Japuí a pertinência é baixa, uma vez que os reais objetivos de tal empreendimento não eram direcionados a esta comunidade. A coerência dessa política foi alta.

\subsubsection{Inauguração da Unidade Básica de Saúde}

A implementação dessa política pública aconteceu em 1981 e, considerando menções feitas por alguns moradores, sua coerência não foi alta, nem sua eficácia:

- “Eu nunca vi um posto de saúde fechar de sábado e domingo, nós somos uma comunidade bem grande e quando fecha dos dois lados de automóvel, nós não temos pra onde correr."

- “Na UBS, não temos ambulância."

Os impactos dessa política são positivos, uma vez que o bairro é isolado tanto de São Vicente, quanto de Praia Grande, cujos acessos podem ser demorados, e com a criação do UBS as pessoas podem ter um pronto atendimento no bairro. A 
pertinência dessa política é alta pelos mesmos motivos que os impactos são positivos.

\subsubsection{Implantação do asfalto}

A coerência da implantação do asfalto no bairro, em meados de 1980, não é alta, uma vez que até hoje existem ruas sem asfalto e em condição precária. Ainda reforçando a baixa coerência tem-se o fato de que os moradores tiveram que pagar pela obra, embora já pagassem impostos. A eficácia dessa política também foi baixa, pelo motivo de só ter contemplado parte do bairro, deste modo os benefícios de acessibilidade, melhoria de infra-estrutura e de conforto não foram plenamente atendidos, mas ocorreram. O impacto negativo foi o fato de que os moradores que chegaram no bairro depois que o asfalto foi feito não tiveram a opção de não pagar por essa obra. Quanto à pertinência dessa política pode-se considerar alta. A seguir a fala de uma moradora sobre esta política pública:

- “(...) veio o calçamento, que todo mundo pagou, quando eu comprei aqui já estava feito, não foi nada feito de graça e eu tive que pagar.”

\subsubsection{Criação da E.E. "Antonio Luiz Barreiros"}

Criada em 1986, essa foi outra política pública que contou com a manifestação de moradores do bairro, de acordo com a fala de uma moradora;

- "Escola só tinha uma, a comunidade correu atrás pra conseguir a escola do estado. A comunidade foi a uma reunião em Peruíbe, levou uma carta para o secretário da educação pedindo uma escola, aí o prefeito não queria fazer (...) aí com muita lu ta veio a escola estadual."

Considerando que o objetivo da criação dessa escola foi aumentar a oportunidade de estudo no bairro a eficácia dessa política não pode ser classificada como alta até 1989 , bem como sua coerência. Até então a escola só contava com o Ensino Fundamental e as pessoas ainda tinham que estudar fora do bairro para cursarem o Ensino Médio. O impacto foi positivo pelo aumento do número de vagas escolares no bairro e posteriormente com a implantação do ensino médio. A pertinência foi alta, ainda mais considerando que a implantação dessa política contou com a mobilização de moradores do bairro. 


\subsubsection{Criação do PEXJ}

A criação do Parque em 1993 teve baixa coerência pela falta de recursos financeiros. Até hoje não foi concluída a regularização fundiária do território, o local onde se instala atualmente a sede administrativa foi cedido pela Marinha, não foram feitos os investimentos necessários para a implantação de infra-estruturas, como centro de visitantes e trilhas. Também contou com a falta de recursos humanos e físicos, não sendo contrato um número adequado de funcionários e não sendo criado um Conselho Gestor. As falas do Sr. Júlio Vellardi demonstram a falta de recursos:

- "Nós tivemos que tirar o efetivo de Cubatão (atual núcleo Itutinga Pilões do Parque Estadual da Serra do Mar) pra vir tomar conta daqui (PEXJ).”

- Todo dia vinha uma equipe de Cubatão pra rodar aqui, isso funcionou até 1996."

- “Esse mesmo (gestor nomeado ao Parque em 1997) montou aqui, a quase 8 quilômetros do Parque, a sede administrativa.”

- "O Parque tinha um diretor e uma secretária."

A eficácia dessa política também é baixa, uma vez que de acordo com o decreto de sua criação a finalidade do Parque era assegurar a integral proteção dos ecossistemas do território, o que, como demonstram inúmeros resultados aqui obtidos, não acontece. Este grau de eficácia também é atribuído ao não cumprimento das finalidades culturais, educativas e recreativas a que um Parque esta submetido, assim como previsto no Decreto $n^{\circ} 84.017$ que regulamenta os Parques nacionais. Ainda hoje, considerando as disposições presentes no SNUC a eficácia continua sendo baixa, uma vez que o Parque não dispõe de um Conselho Consultivo e não cumpre inúmeras diretrizes do SNUC.

A pertinência dessa política foi alta considerando que inúmeros segmentos solicitaram a criação do Parque e as potencialidades econômicas, ecológicas, educacionais, sociais e culturais da área.

Os impactos da criação do Parque para a comunidade do Japuí são percebidos por esta, tanto como negativos quanto como positivos. As falas a seguir demonstram percepções sobre os impactos negativos pelos moradores:

- "Trazia mais benefícios (antes da criação do Parque) do que agora. Era peixe, o pessoal pescava bem.” 
- “Agora o Parque não traz mais nada (referindo-se aos benefícios), por que está parado, é uma obra completamente parada."

Os impactos positivos decorrem da manutenção do território do Parque ao longo do tempo, uma conseqüência de sua criação. De acordo com os moradores, assim como já apresentado, tais efeitos dizem respeito à recreação, obtenção de recursos, beleza, segurança, aprendizado, serviços do meio ambiente e, de maneira indireta, também se relacionam com benefícios econômicos.

A área do Parque poderia ter sofrido ações da especulação imobiliária direcionada a um público com poder aquisitivo alto, devido à atratividade cênica do local e as intenções de implantação de empreendimentos que atenderiam tal especulação. Caso o Parque não tivesse sido criado, muito provavelmente o cenário anterior teria se estabelecido, o que poderia levar ao deslocamento da comunidade do Japuí para outras áreas, visto que o poder econômico envolvido com tal empreendimento é muito alto, podendo facilmente adquirir as propriedades dos moradores adjacentes. Tal cenário de acontecimentos foi observado em áreas similares do município do Guarujá, onde, para a construção de condomínios de alto padrão relatou-se, até mesmo, formas violentas de intimidação contra moradores locais (Gonçalves, 2008, no prelo).

\subsubsection{Fase 1 do Plano de Manejo}

Pertinência alta, a partir do momento que é uma disposição legal que o Plano de Manejo seja elaborado no prazo de cinco anos após a criação da UC.

Os impactos foram negativos e dizem respeito a não implementação dessa fase, o que fortaleceu o distanciamento com a comunidade, acirrando a ausência de comunicação e tornou-se um dos motivos do conflito entre o Parque e a ONG. Considerando que o objetivo do Plano de Manejo é compatibilizar a preservação dos ecossistemas com a utilização dos benefícios deles advindos, baseia-se em estudos visando diretrizes para um manejo ecológico e levando em conta o conteúdo do documento elaborado para a fase 1 , tanto a eficácia quanto a coerência foram baixas.

\subsubsection{Criação das creches}

As creches Dr. Luiz Gonzaga de Oliveira Gomes e Olinda Cury Gigliotti foram criadas em 1997 e 2004, respectivamente. A eficácia e coerência dessas obras 
podem ser classificadas como alta, uma vez que uma moradora afirmou que pelo menos a primeira é muito boa, comparando-a a uma creche particular. Os impactos dessa política são positivos e a pertinência alta considerando que a população também se mobilizou para que as creches fossem criadas. É importante destacar que desde as primeiras reivindicações dos moradores até a implantação das creches decorreu um período de aproximadamente onze anos, de acordo com uma moradora que fez parte do processo.

A política pública de implantação do sistema de captação de esgoto não foi avaliada pela falta de indicadores.

É importante mencionar que as políticas públicas incidentes sobre o Japuí analisadas aqui, são políticas de infra-estrutura básica para uma comunidade, sendo assim é fácil que a pertinência dessas seja alta e que seus impactos sejam em sua maioria positivo. Outro ponto a se destacar é que a comunidade se mobilizou para que muitas das políticas fossem implantadas, isso demonstra um descaso do poder público para com o bairro, ainda mais considerando que se tratava, na grande maioria, de obras de infra-estrutura básica. Essa busca pelas políticas mostra que, pelo menos durante certo período, houve uma organização social, entretanto, mesmo com demandas locais o poder público não se mostrou capaz de executar boas políticas, como mostraram as análises. A Tabela 13 representa a avaliação das políticas incidentes no território do bairro Japuí. 
Tabela 13 - Representação da avaliação de políticas públicas do bairro Japuí de 1960 à 2004.

\begin{tabular}{|c|c|c|c|c|c|c|}
\hline $\begin{array}{ll} & \text { Item } \\
& \\
\text { Política } & \end{array}$ & $\begin{array}{c}\text { Esfera de poder } \\
\text { executivo }\end{array}$ & Coerência & Pertinência & Eficácia & Impactos Positivos & Impactos Negativos \\
\hline $\begin{array}{l}\text { Instalação da } \\
\text { rede elétrica }\end{array}$ & Municipal & $\rightarrow / \Delta$ & $\Delta$ & $>/ \Delta$ & $\begin{array}{l}\text { Disponibilidade de } \\
\text { energia elétrica }\end{array}$ & \\
\hline $\begin{array}{l}\text { Aterro e } \\
\text { implantação de } \\
\text { comportas }\end{array}$ & Municipal & $\boldsymbol{\nu}^{*}$ & $\Delta$ & $\Delta$ & $\begin{array}{l}\text { Contenção de } \\
\text { enchentes, facilitação } \\
\text { do deslocamento }\end{array}$ & $\begin{array}{l}\text { Prejuízos ambientais, quanto } \\
\text { à saúde e manutenção de } \\
\text { infra-estrutura das casas }\end{array}$ \\
\hline $\begin{array}{l}\text { EMEIEF "Maria } \\
\text { Mathilde de } \\
\text { Santana" }\end{array}$ & Municipal & $>$ & $\Delta$ & & $\begin{array}{l}\text { Aumento do número de } \\
\text { vagas escolares no } \\
\text { bairro }\end{array}$ & \\
\hline
\end{tabular}

continua... 


\begin{tabular}{|c|c|c|c|c|c|c|}
\hline $\begin{array}{ll} & \text { Item } \\
\text { Política } & \end{array}$ & $\begin{array}{l}\text { Esfera de poder } \\
\text { executivo }\end{array}$ & Coerência & Pertinência & Eficácia & Impactos Positivos & Impactos Negativos \\
\hline Criação da UBS & Municipal & $\rightarrow$ & $\Delta$ & $\rightarrow$ & $\begin{array}{l}\text { Atendimento médico no } \\
\text { bairro }\end{array}$ & \\
\hline $\begin{array}{l}\text { Implantação do } \\
\text { asfalto }\end{array}$ & Municipal & & $\Delta$ & & $\begin{array}{c}\text { Melhoria na infra-estrutura } \\
\text { do bairro, conforto e } \\
\text { acesso }\end{array}$ & $\begin{array}{c}\text { Moradores que chegaram } \\
\text { no bairro depois do asfalto } \\
\text { tiveram que pagar }\end{array}$ \\
\hline $\begin{array}{l}\text { E. E. Antonio } \\
\text { Luiz Barreiros }\end{array}$ & Municipal & $\rightarrow / 4$ & $\Delta$ & & $\begin{array}{l}\text { Aumenta vagas escolares e } \\
\text { criação do Ensino Médio }\end{array}$ & \\
\hline $\begin{array}{l}\text { Criação das } \\
\text { Creches }\end{array}$ & Municipal & $\Delta$ & $\Delta$ & $\Delta$ & $\begin{array}{c}\text { Vagas para crianças no } \\
\text { bairro }\end{array}$ & \\
\hline $\begin{array}{l}\text { Criação do } \\
\text { PEXJ }\end{array}$ & Estadual & $\nabla$ & $\Delta$ & $\nabla$ & $\begin{array}{c}\text { Manutenção do território } \\
\text { do PEXJ }\end{array}$ & $\begin{array}{l}\text { Proibições e abandono que } \\
\text { torna a área improdutiva }\end{array}$ \\
\hline $\begin{array}{l}\text { Fase } 1 \text { do Plano } \\
\text { de Manejo }\end{array}$ & Estadual & & $\Delta$ & & & $\begin{array}{l}\text { Induz o distanciamento com } \\
\text { a comunidade; é um motivo } \\
\text { do conflito a ONG }\end{array}$ \\
\hline
\end{tabular}

Legenda:

* Caso o aterro tenha sido feito com resíduos da Cosipa e lixo de Santos

- A política é coerente, pertinente ou eficaz

$\longrightarrow$ A política é parcialmente coerente, pertinente ou eficaz

$\downarrow$ A política é incoerente, impertinente ou ineficaz 


\section{CONSIDERAÇÕES FINAIS}

Tomando por base os dados obtidos nesse trabalho fica claro que existe um cenário complicado, porém reversível, em torno do PEXJ, sua administração e a comunidade do bairro Japuí.

Esse é um bairro historicamente abandonado pelo poder público, o que parece seguir a tendência nacional, na qual as tomadas de decisão são verticais e descendentes. A comunidade se mostrou organizada quando se tratava das necessidades básicas de um cidadão. Entretanto, igual organização não é observada quando se trata de questões ambientais, que muitas vezes são entendidas como secundárias. Influenciando tal entendimento tem-se, por exemplo, o baixo grau de instrução dos moradores.

Sugere-se que ações de gestão participativa sejam implementas pela administração do PEXJ para que seus objetivos culturais, educacionais e sociais sejam alcançados de maneira integrada e atendam às diferentes expectativas. Tudo isso somado ao cumprimento dos objetivos conservacionistas desta UC, já que o manejo e a conservação ecológica tendem a ser mais efetivos quando a gestão é participativa.

Para que as pessoas apresentem-se efetivamente aptas em contribuir para a gestão participativa efetiva e para a formação do cenário do PEXJ, dentre outros fatores, é de suma importância que a comunidade seja informada sobre os preceitos, legalidades e potencialidades do Parque. Essa informação, como demonstram os resultados obtidos, deve abranger os temas mais básicos sobre o Parque e o meio ambiente.

Instituições atuantes na área do Parque devem e podem agir de forma integrada para a implementação da gestão participativa. Este é o caso da ONG "SOS Itaquitanduva" que está inserida no bairro, no entanto deve antes de mais nada estabelecer uma relação não conflituosa com a administração do Parque e tornar-se realmente representativa no Japuí. A UNESP é vista como uma instituição capaz de intermediar o relacionamento entre esses segmentos, tan to pelo órgão gestor do PEXJ, quanto pela ONG, que certa vez solicitou ao IF que a gestão do Parque fosse feita por esta universidade.

Espera-se que a re-elaboração da fase 2 do Plano de Manejo seja baseada em 
processos participativos e que aponte diretrizes, aplicáveis e de possível execução, para o cumprimento dos preceitos sócio-ecológicos do Parque. 


\section{CONCLUSÃO}

A criação do PEXJ não dispôs de um planejamento prévio, visto que nem recursos humanos, nem infra-estrutura eram disponíveis para sua implementação. Mesmo assim esta unidade contribuiu para a diminuição de práticas extrativistas no território, o que retomou antigas condições ambientais em áreas adjacentes.

Percebe-se alta afetividade dos moradores pela área do Parque e baixa informação ambiental e conhecimento em relação aos assuntos que cercam a unidade. Ao mesmo tempo, o envolvimento da comunidade com o Parque é muito baixo. Está situação é reflexo do histórico abandono no bairro e do processo de criação do Parque, o qual não incluiu as comunidades de entorno nos debates.

O Parque Estadual Xixová-Japuí está inserido num contexto de animosidades com a comunidade do Japuí. Fica claro a falta de interesse dos moradores, a baixa disposição tanto da ONG quanto da administração do Parque em lidar com uma situação conflituosa e a falta de disponibilidade de informações relevantes do Parque à esta comunidade.

Esforços individuais destes segmentos visando quebrar paradigmas e cumprir certas obrigações, e a atuação de uma entidade cujo potencial tradutor seja amplo o suficiente em lidar com instituições engessadas, com pessoas sem informação e com entidades cujo real propósito pode parecer controverso, são medidas de grande importância para contornar a atual situação estática e conflituosa entre o PEXJ e a comunidade do bairro Japuí. 


\section{REFERÊNCIAS}

AFONSO, C. M. A paisagem da Baixada Santista: urbanização, transformação e conservação. São Paulo: Editora da Universidade de São Paulo: FAPESP, 2006. $310 \mathrm{p}$.

AMARAL, G. Projeto Informação da Paisagem e Conservação Ambiental novas ferramentas para conservação do Parque Estadual da Serra do Mar Núcleo São Sebastião - SP. 2004. Disponível em: <www.corredores.org.br/?pageId=adminOpenDoc\&docId=2416>. Acesso em: 20 mar. 2008.

AMARAL, W. A. N.; BRITO, M. C. W.; ASSAD, A. L. D.; MANFIO, G. P. Políticas Públicas em Biodiversidade: Conservação e uso Sustentado no País da Megadiversidade. $2000 . \quad$ Disponível em: <www.hottopos.com/harvardl/politicas....publicas...em_biodiversi.htm>. Acesso em: 21 mar. 2008.

AS \& GESET. Terceiro Setor e desenvolvimento social. Relato Setorial Nº 3, 2001. $35 \mathrm{p}$.

BAPTISTA, N.; PEIXOTO, E. Gestão de políticas públicas. In: Programa de formação de lideranças e técnicos em desenvolvimento local sustentável. Brasília: CONTAG, 1999. (Módulo III).

BORRINI-FEYERANBEND, G. Manejo participativo de áreas protegidas adaptando o método ao contexto. Temas de política social. Quito: IUCN-SUR, 1997. $67 \mathrm{p}$.

BRASIL. Ministério do Meio Ambiente. Sistema Nacional de Unidades de Conservação - SNUC. Brasília, DF, 2000. 23p.

BRÜSEKE, F. J. O problema do desenvolvimento sustentável. In: CAVALCANTI, C. (Org.) Desenvolvimento e natureza: Estudos para uma sociedade sustentável. Recife: INPSO/FUNDAJ, Instituto de Pesquisas Sociais, Fundação Joaquim Nabuco, Ministério de Educação, Governo Federal, Recife, 1994. 262p.

CONSEIL SCIENTIFIQUE DE L'EVALUATION. Petit guide de l'évaluation des politiques publiques. Paris: La Documentation Française, 1996. 123 p.

CUNHA, I. A. Política ambiental local, negociação de conflitos e sustentabilidade: 
São Sebastião, costa norte de São Paulo. In: ABRAMOVAY, R. (Org.).

Construindo a Ciência Ambiental. São Paulo: Annablume - FAPESP, 2002.

DE LA MAZA, C. L. Manejo de reservas de la biosfera. Documento Técnico ${ }^{\circ} 15$. Santiago: FAO/PNUMA,1994. 115 p.

DIEGUES, A.C.; MOREIRA, A.C.C. (Orgs.). Espaços e recursos naturais de uso comum. São Paulo: HUCITEC/NUPAUB, 2001. 294p.

FALCONER, A. P. A promessa do terceiro setor. 1999. 152p. Dissertação (Mestrado Faculdade de Economia, Administração e Contabilidade)-FEA-USP, São Paulo, 1999.

FRANCISCO, V. F. A área continental santista sob ótica do processo de planejamento territorial de Santos de 1967 a 1999. 2000. 439p. Dissertação (Mestrado)-Faculdade de arquitetura e Urbanismo, USP, São Paulo, 2000.

GONÇAlVES, P. S. F. A comunidade da Cachoeira, na Serra do Guararu, Guarujá/SP: um estudo sócio-ecológico. 2008. 107p. Trabalho de Conclusão (Graduação em Ciências Biológicas)-Universidade Estadual Paulista, São Vicente, 2008.

GOMES, L. J. Conflitos entre a conservação e o uso da terra em comunidades rurais no entorno do Parque Nacional da Serra da Bocaina: uma análise interpretativa. 2002. 162p. Dissertação (Doutorado em Engenharia Agrícola)Universidade Estadual de Campinas, Campinas, 2002.

HAUFF, S. N. Relações entre comunidades rurais locais e administração de Parques no Brasil: subsídios ao estabelecimento das zonas de amortecimento. 2004. 208p. Dissertação (Doutorado em Engenharia Florestal)Universidade Federal do Paraná, Curitiba, 2004.

IBAMA \& WWF Brasil. Efetividade de Gestão das Unidades de Conservação Federais do Brasil - implementação do método RAPPAM - Avaliação Rápida e Priorização da Gestão de Unidad es de Conservação. Brasília, 2007. 96p. Disponível em: <http://assets.wwf.org.br/downloads/efetividade_de_gestao_das_unidades_de_co nservacao_federais_do_Brasil.pdf $>$. Acesso em: 20 mar. 2008.

LEWINSOHN, T. M.; PRADO, P. I. Quantas espécies há no Brasil? Revista Megadiversidade, v. 1, n. 1, p. 36-42, jul. 2005. 
LIMA, G. S.; RIBEIRO, G. A.; GONÇALVES, W. Avaliação da efetividade de manejo das unidades de conservação de proteção integral em Minas Gerais. Revista Árvore, v. 29, n. 29, p. 647-653, 2005.

LUCAS, P. H. C. Protected Landscapes. A guide for policy-makers and planners. The IUCN Protected Areas Programme. London: Chapman \& Hall. 1992. 297 p.

LUTGENS, H. D. Caracterização ambiental e subsídios para o manejo da zona de amortecimento da Estação Experimental e Ecológica de Itirapina - SP. 2000. 62p. Dissertação (Mestrado)-Universidade Estadual Paulista "Júlio de Mesquita Filho", Rio Claro, 2000.

MACEDO, N. F. São Vicente, 1532 - 1992. São Paulo: EF Editora, 1992. 103p.

MAGALHÃES, A. R. Um estudo de desenvolvimento sustentável do Nordeste semiárido. In: CAVALCANTI, C. (Org.) Desenvolvimento e natureza: Estudos para uma sociedade sustentável. Recife: INPSO/FUNDAJ, Instituto de Pesquisas Sociais, Fundação Joaquim Nabuco, Ministério de Educação, Governo Federal, Recife, 1994. 262p.

OLIVA, A. Programa de manejo fronteiras para o Parque Estadual XixováJapuí. 2003. 239p. Dissertação (Mestrado em Recursos Florestais)-Escola Superior de Agricultura Luiz de Queiroz, Piracicaba, 2003.

OLIVEIRA, I. A. O. Gestão de conflitos em Parques: estudo de caso do entorno nordeste do Parque Estadual da Serra do Tabuleiro - Praia da Pinheira SC. 2005. 169p. Dissertação (Doutorado em Engenharia de Produção e Sistemas)-Universidade Federal de Santa Catarina, Florianópolis, 2005.

OLIVEIRA, F. B. R. Estratégia de informação para gestão de unidades de conservação. 2006. 77p. Trabalho de Conclusão (Graduação em Ciências Biológicas)-Universidade Estadual Paulista, São Vicente, 2006.

ORGANIZAÇÃO DAS NAÇÕES UNIDAS. Declaração de Estocolmo sobre o ambiente humano. Estocolmo, Declaração da Conferência das Nações Unidas sobre o Meio Ambiente Humano, 1972.

PIEVE, S. M. N.; MIURA, A. K.; BORBA, I. C.; ALMEIDA, O. B.; LANGIE, S. S. Estudos etnoictiológicos da comunidade de pescadores Z3, Pelotas, RS. Resultados Preliminares, 2006.

QUEIROZ, F. A.; SILVA, L. J. M. O Sistema Nacional de Unidades de 
Conservação da Natureza (SNUC) e a Participação Popular. A Lei n. ${ }^{\circ}$ 9985/2000. In: $8^{\circ}$ CONGRESSO BRASILEIRO DE ADVOCACIA PÚBLICA: INSTRUMENTOS DE PROTEÇÃO DO MEIO AMBIENTE E DO ERÁRIO, 2004, Foz do Iguaçu, Paraná.

QUEIROZ, F. A. Meio Ambiente e Comércio Internacional: Relação Sustentável ou Opostos Inconciliáveis? 2003. Dissertação (Mestrado em Desenvolvimento Sustentável)-Universidade de Brasília, Brasília, 2003.

REIGOTA, M. O que é educação ambiental. São Paulo:BRASILIENSE, 1991.63p.

RONCAGLIO, C.; SZVARÇA, D. R.; BOJANOSKI, S. F. Arquivos, gestão de documentos e informação. R. Eletr. Bibl. Ci. Inf., Florianópolis, 2004, ano 9, n. esp., p. 1-13, 2004.

RYLANDS, A. B.; BRANDON, K. Unidades de conservação Brasileiras. Megadiversidade, v. 1, n. 1, p. 27-35, 2005.

SÃO PAULO (Estado). Decreto $n^{\circ}$ 49.672, de 6 de Junho de 2005. Disponível em: $<$ http://www.legislacao.sp.gov.br/legislacao/index.htm>. Acesso em: 17 abr. 2008.

SÃO PAULO (Estado). Secretaria do Meio Ambiente. Parque Estadual XixováJapuí - Plano de Manejo - Fase 1 - Consolidação de Dados e Diretrizes Preliminares. São Paulo: Coordenadoria de Informações Técnicas, Documentação e Pesquisa Ambiental; Instituto Florestal; Instituto e Botânica; CEPEL/UNESP, 1997. 74p. (Série Documentos Ambientais).

SECRETARIA DE EDUCAÇÃO DE SÃO VICENTE. Apostila elaborada pela equipe da Secretaria de Educação de São Vicente. [1998], 203p.

SEKIGUCHI, C.; PIRES, E. L. S. Agenda para uma economia política da sustentabilidade: potencialidades e limites para o seu desenvolvimento no Brasil. In: CAVALCANTI, C. (Org.) Desenvolvimento e natureza: Estudos para uma sociedade sustentável. Recife: INPSO/FUNDAJ, Instituto de Pesquisas Sociais, Fundação Joaquim Nabuco, Ministério de Educação, Governo Federal, Recife, 1994. 262p.

SEQUINEL, M. C. M. Cúpula mundial sobre desenvolvimento sustentável Joanesburgo: entro o sonho e o possível. Análise Conjuntural, v. 24, n. 11-12, $12 \mathrm{p}, 2002$. 
SILVA, J. A. Direito Ambiental Constitucional. São Paulo: MALHEIROS EDITORES, 2003. 350p.

SILVA, N. J. R. da et al. Modelo teórico de análise de políticas públicas e desenvolvimento: um exemplo de aplicação na piscicultura. Rev. de Economia Agrícola, v. 54, n. 2, p. 43-66, 2007.

SIMON, A. V. S. Conflitos na conservação da natureza: o caso do Parque Estadual da Serra da Tiririca. In: II ENCONTRO NACIONAL DA ASSOCIAÇÃO NACIONAL DE PÓS-GRADUAÇÃO E PESQUISA EM AMBIENTE E SOCIEDADE, 2004, Indaiatuba. Disponível em: <http://www.anppas.org.br/encontro_anual/encontro2/GT/GT08/alba_simon.pdf >. Acesso em: 05 abr. 2008.

SOARES, M. C. C.; BENUSAN, N.; FERREIRA-NETO, P. S. Entorno de Unidades de Conservação: estudo de experiências em UC's de proteção integral. Rio de Janeiro: FUNBIO, 2004. 112 p.

VALLEJO, L. R. Unidades de Conservação: uma discussão teórica à luz dos conceitos de territórios e de políticas públicas. Geographia, v. 4, n. 8, p. 77-106, 2003.

VIEIRA, P. F. Gestão patrimonial de recursos naturais: construindo o ecodesenvolvimento em regiões litorâneas. In: CAVALCANTI, C. (Org.) Desenvolvimento e natureza: Estudos para uma sociedade sustentável. Recife: INPSO/FUNDAJ, Instituto de Pesquisas Sociais, Fundação Joaquim Nabuco, Ministério de Educação, Governo Federal, Recife, 1994. 262p.

WWF-Brasil. Unidades de Conservação: conservando a vida, os bens e os serviços ambientais. São Paulo, 2007. 23p. Disponível em: $<$ http://assets.wwf.org.br/downloads/cartilha_ucs.pdf>. Acesso em: 27 mar. 2008. Acesso em: 02 abr. 2008. 


\section{ANEXOS}

\section{Anexo 1 - Questionário aplicado aos moradores}

1. Sexo:

2. Qual a sua idade?

3. Qual sua escolaridade?

4. Qual sua profissão?

5. Há quanto tempo você mora no bairro?

6. Você visita ou já visitou o Parque Estadual Xixová-Japuí?

7. Com que freqüência?

8. Quais atividades você pratica ou praticou no Parque?

9. Conhece algum animal e/ou vegetal do PEXJ? Qual (is)?

10. O que faz o PEXJ ser diferenciado em relação a outras áreas verdes que você conhece?

11. Você sabe que essa área é protegida pela lei?

12. Você sabe quais atividades são permitidas no Parque?

13. Você sabe quais atividades são proibidas no Parque?

14. Você conhece ou já viu alguém fazendo alguma dessas atividades proibidas?

15. Você conhece ou já viu alguém fazendo alguma dessas atividades permitidas?

16. Você já detectou algum problema no Parque? Qual (is)?

17. O que você acha que pode ser feito para corrigir esses problemas?

18. Sobre o PEXJ, você acha que traz algum benefício para a população? Qual (is)?

19. Você acha que o PEXJ traz algum prejuízo para a população? Qual (is)?

20. Você sabe se o Parque tem uma sede administrativa? Se sim, sabe onde fica instalada?

21. Você foi convidado ou ficou sabendo de alguma reunião ou evento sobre o Parque? Quem convidou?

22. O que você acha da divulgação de informações de assuntos do Parque para a comunidade?
( ) Boa
( ) Regular
( ) Ruim
( ) Não sei 
23. Como você considera sua relação com o diretor do Parque?
( ) Boa
( ) Regular
( ) Ruim
( ) Não se relaciona

24. Como você qualificaria a gestão do Parque?
( ) Boa
( ) Regular
( ) Ruim
( ) Não sei

25. E o relacionamento da comunidade com o PEXJ?
( ) Bom/ativo
( ) Regular
( ) Ruim
( ) Não sei

26. Você faz parte de alguma ONG ou outra associação relacionada ao Parque? Qual?

27. Você tem interesse em participar do desenvolvimento de alguma atividade relacionada ao Parque?

28. Existe algum órgão ou alguém que represente os interesses da comunidade para o PEXJ?

29. Você tem alguma sugestão ou crítica que gostaria de fazer sobre o Parque? 


\section{Anexo 2 - Questionário aplicado aos membros da ONG}

1. Sexo:

2. Qual a sua idade?

3. Qual sua escolaridade?

4. Qual sua ocupação na ONG?

5. Há quanto tempo está na ONG?

6. Você visita ou já visitou o Parque Estadual Xixová-Japuí?

7. Com que frequiência?
( ) Muitas vezes
( ) Poucas vezes
( ) Não visita

8. Quais atividades você pratica ou praticou no Parque?

9. Conhece algum animal e/ou vegetal do PEXJ? Qual (is)?

10. O que faz o PEXJ ser diferenciado em relação a outras áreas verdes que você conhece?

11. Você sabe quais atividades são permitidas no Parque?

12. Você sabe quais atividades são proibidas no Parque?

13. Você conhece ou já viu alguém fazendo alguma dessas atividades proibidas?

14. Você conhece ou já viu alguém fazendo alguma dessas atividades permitidas?

15. Você já detectou algum problema no Parque? Qual (is)?

16. O que você acha que deve ser feito para corrigir esses problemas?

17. Sobre o PEXJ, você acha que traz algum benefício para a população? Qual (is)?

18. Você acha que o PEXJ traz algum prejuízo para a população? Qual (is)?

19. Você foi convidado ou ficou sabendo de alguma reunião ou evento sobre o Parque?

20. O que você acha da divulgação de informações de assuntos do Parque para a comunidade?
( ) Boa
( ) Regular
( ) Ruim
( ) Não sei

21. Como você considera sua relação com o diretor do Parque?
( ) Boa
( ) Regular
( ) Ruim
( ) Não se relaciona

22. Como você considera a relação da ONG com a administração do Parque?
( ) Boa
( ) Regular
( ) Ruim
( ) Não sei 
23. Como você qualificaria a gestão do Parque? Por quê?
( ) Boa
( ) Regular
( ) Ruim
( ) Não sei

24. E o relacionamento da comunidade com o PEXJ?
( ) Bom/ativo
( ) Regular
( ) Ruim
( ) Não sei

25. Os moradores do Japuí procuram a ONG para tratar de assuntos relacionados ao Parque? Qual (is)?

26. Você reconhece a ONG como uma entidade que representa os interesses da comunidade do bairro para a administração do PEXJ?

27. Você tem alguma sugestão ou crítica que gostaria de fazer sobre o Parque?

28. Quando a ONG foi criada e quando passou a ser oficial sua existência?

29. Quais são os projetos da ONG? Quais destes são voltados à comunidade do Japuí?

30. A ONG buscou estabelecer parceria com a diretoria do Parque ou com alguma outra instituição? Que tipo de parceria? Qual foi o resultado? 


\section{Anexo 3 - Questionário aplicado ao gestor do PEXJ}

1. Nome:

3. Qualé a sua formação? Há quanto tempo exerce a função de gestor do Parque?

3. As fases desenvolvidas do plano de manejo tiveram participação da comunidade? Como? Você acha que os procedimentos adotados foram adequados?

5. Quais são as dificuldades para que o Conselho Consultivo seja estabelecido?

6. Você acha que há urgência na formação desse Conselho? Por quê?

7. Você reconhece algum segmento de sociedade organizada no entorno do Parque?

8. Como a direção do Parque integra ou prevê integrar a comunidade a fim de obter melhores resultados de gestão e manejo?

9. Você detectou alguma dificuldade em inserir a comunidade nos assuntos e práticas de conservação do meio ambiente?
( ) $\operatorname{Sim}($ ) Não
Quais?

10. Caso não haja problemas, quais são os pontos positivos em relação à inserção da comunidade?

11. Você acha que alguma prática do Parque diverge dos interesses da comunidade? Qual (is)?

12. Você acha que a comunidade sente algum tipo de prejuízo com a existência do Parque?

13. Já aconteceu alguma situação de conflito de interesses entre o PEXJ e a comunidade?

14. Você acha que a comunidade traz algum impacto negativo ao Parque? Qual (is)?

15. Como você acha que a comunidade poderia contribuir para a conservação da área?

16. Como você caracteriza o interesse da comunidade de entorno sobre assuntos de gestão e manejo do Parque?

17. Como você qualifica o relacionamento entre a comunidade e o Parque (em relação ao território e à administração)? Quais as razões dessa avaliação? 
